\title{
nombalina
}

(8)

\section{Marcial en Espana}
Autor(es):
Gil, Juán
Instituto de Estudos Clássicos, Centro de Estudos Clássicos e
Publicado por:
Humanísticos; Departamento de Estudos Clássicos, Centro de Estudos Clássicos

\author{
URL \\ persistente: \\ URI:http://hdl.handle.net/10316.2/34638 \\ DOI: \\ DOI:http://dx.doi.org/10.14195/978-989-26-0901-0_12
}

Accessed : $\quad$ 26-Apr-2023 15:38:37

A navegação consulta e descarregamento dos títulos inseridos nas Bibliotecas Digitais UC Digitalis, UC Pombalina e UC Impactum, pressupõem a aceitação plena e sem reservas dos Termos e Condições de Uso destas Bibliotecas Digitais, disponíveis em https://digitalis.uc.pt/pt-pt/termos.

Conforme exposto nos referidos Termos e Condições de Uso, o descarregamento de títulos de acesso restrito requer uma licença válida de autorização devendo o utilizador aceder ao(s) documento(s) a partir de um endereço de IP da instituição detentora da supramencionada licença.

Ao utilizador é apenas permitido o descarregamento para uso pessoal, pelo que o emprego do(s) título(s) descarregado(s) para outro fim, designadamente comercial, carece de autorização do respetivo autor ou editor da obra.

Na medida em que todas as obras da UC Digitalis se encontram protegidas pelo Código do Direito de Autor e Direitos Conexos e demais legislação aplicável, toda a cópia, parcial ou total, deste documento, nos casos em que é legalmente admitida, deverá conter ou fazer-se acompanhar por este aviso.

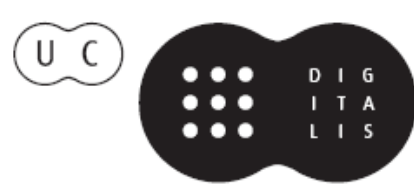




\section{Toto notus in orbe Martialis}

\section{Celebração de Marcial \\ 1900 anos após a sua morte}

Coordenação

Cristina de Sousa Pimentel

Delfim F. Leão

José Luís L. Brandão

Instituto de Estudos Clássicos

Centro de Estudos Clássicos e Humanísticos

UNIVERSIDADE DE COIMBRA
Departamentō de Estudos Clássicos Centro de Estudos Clássicos UNIVERSIDADE DE LISBOA 


\title{
MARCIAL EN ESPAÑA*1
}

JUAN GIL

Universidad de Sevilla

\begin{abstract}
In this article special attention is paid to the influence of Martial in literature and classical philology from Spain, mainly in what concerns works written in Latin, until and including the XVIIth century.
\end{abstract}

En 103, muy probablemente, murió Marco Valerio Marcial. En un mundo como el nuestro, que tanto gusta de celebrar aniversarios para justificar olvidos, éste es, pues, el momento apropiado de dedicar algún recuerdo a su figura, rastreando la pervivencia que tuvo su obra ("das Fortleben", que dirían los alemanes) en nuestra patria a través de los siglos, aunque mi corto entender no me permita prolongar la calicata más allá del s. XVII, y aun eso con harta fatiga y dejando atrás muchos cabos sueltos. A pesar de los defectos e imperfecciones que pueda tener, y los tiene, es de justicia este homenaje. Pocos poetas, en efecto, sintieron tanto apego a su terruño como el poeta de Bílbilis. En sus versos resuenan con orgullo los viejos topónimos celtibéricos (nostrae nomina duriora terrae), algunos de los cuales se conservan todavía hoy: aparte de las equivalencias del río Salo con el Jalón y de Tutela con Tudela, el sanctum Buradonis ilicetum de IV 55, como señaló en su tiempo Menéndez Pidal2, "se identi-

* Os Editores da Humanitas desejam exprimir o seu agradecimento à S.E.L.A.T., por gentilmente ter acedido a que fosse publicado neste volume o artigo do Prof. Juan Gil, que expressará também a sua gratidão nas Actas do II Congresso da S.E.L.A.T., celebrado em Medina del Campo, em 2003.

${ }^{1}$ Quiero agradecer muy de veras las luminosas sugerencias e informaciones que sobre este tema he recibido de los Prof. L. Gil, J. Ma Maestre y J. Pascual, profundos conocedores del Humanismo español.

2 Toponimia prerrománica hispana, Madrid, 1968, p. 258. 
fica de modo indudable en el término de Beratón (partido de Ágreda), en las estribaciones del Moncayo", orónimo que se corresponde a su vez con Caius uetus, monte al que Rodrigo Jiménez de Rada buscaba una imposible etimología mons Caci3i i es asimismo tradicional la identificación de Voberca con Bubierca ${ }^{4}$. Hasta hace muy poco este entusiasmo desbordante del poeta por su patria chica y sus raíces celtibéricas pudo parecer una expresión de provincianismo cateto; ahora, sin embargo, el descubrimiento sensacional de los grandes bronces celtibéricos de Botorrita (la antigua Contrebia Belaisca $)^{5}$ nos ha permitido asomarnos a una cultura indígena floreciente, tronchada al fin y a la postre por la romanización, pero todavía muy viva en el s. I a. C. y sin duda no apagada del todo en el s. I d. C. Estos preciosos testimonios epigráficos nos ayudan a situar en su contexto al poeta, haciendo más comprensible su jactancioso pregón de las glorias patrias y, de paso, sugiriéndonos alguna posible corrección en la nómina de lugares y de nombres. En efecto, en ese mismo epigrama aparece un Manlius demasiado romano:

Et quae fortibus excolit iuuencis

Curuae Manlius arua Vatiuescae.

Me parece probable que este nomen, un poco estridente por su pureza latina entre tanta onomástica autóctona, no sea más que una corrupción de un Maelius celtibérico, nombre propio documentado en inscripciones latinas ${ }^{6}$ y derivado del gentilicio que nos da a conocer la larga nómina del tercer bronce contrebiense: letontu mailikum (I 25), sekilos mailikum (II 23), arkanta mailikum (IV 20)7. No sería ésta la primera vez que

${ }^{3}$ De rebus Hispaniae, I 5 (p. 16, 19 Fernández Valverde); Alfonso X el Sabio, Primera crónica general de España, 7 (I, p. 10 a 47 Menéndez Pidal). Las dos etimologías ("de Caco o Cayo") recuerda B. L. de Argensola, Rimas, 44, 190ss. (ed. de J. M. Blecua, Clás. Cast., I, p. 78).

${ }^{4}$ Cf. M. Dolç, Hispania y Marcial. Contribución al conocimiento de la España antigua, Barcelona, 1953, p. 198ss.

${ }^{5}$ Cf. últimamente F. Villar et alii, El IV bronce de Botorrita (Contrebia Belaisca). Arqueología y Lingüística, Salamanca, 2001.

${ }^{6} \mathrm{Cf} . \mathrm{M}^{\mathrm{a}}$ L. Albertos Firmat, La onomástica personal primitiva de Hispania Tarraconense y Bética, Salamanca, 1966, p. 142.

${ }^{7}$ En el O. peninsular están atestiguadas las formas Maelo y Magela, que probablemente remontan a una raíz independiente *magil- cf. J. Untermann, en 
usara Marcial antropónimos célticos: ahí está Tongilianus en III 52, 1 y 4; XII 89, 1 y 2. La frecuencia de la raíz teuta- 'ciudad' en celtibérico nos anima a aceptar con M. Dolç la forma Toutonissa, parangonable con Toutissa, Toutissia, Toutissicnos, en vez de Tuetonissa (con un grupo inicial tw- hasta ahora desconocido). Rixamae (¿de la misma raíz que Rigae?) ${ }^{9}$ parece encubrir un antiguo superlativo en -samos, como Vxama ${ }^{10}$. En cambio, el barniz griego ${ }^{11}$ que tiene Platea, en vez de un ${ }^{*}$ Letea (cf. celtibérico Ledaisama y ${ }^{*}$ Bletisama y galo Letauia) ${ }^{12}$, ha de ser coquetería del propio autor y no corrupción de la transmisión manuscrita.

Marcial, el epigramatista de moda en Roma, volvió lleno de días y colmado de gloria si no de dinero a su Bílbilis natal. Antes y después de su regreso, extraña que no dejara en Hispania huella inmediata y apreciable de su ingenio. P. Piernavieja ${ }^{13}$ intentó suplir esta laguna atribuyendo al bilbilitano el epigrama en dísticos que los libertos Flavio Rufino y Sempronio Diófanes dedicaron al auriga Éutiques, arrebatado por una cruel enfermedad en plena juventud antes de que pudiera alcanzar la gloria en el circo. La inscripción, muy bonita, tiene asperezas que no son propias de Marcial (como el paso de la tercera a la primera persona en v. 8); por otra parte, la grafía forsitam analógica de tam, grafía que estropea el verso, preludia ya la manía etimologizante que va a imperar en épocas más tardías. Hemos de resignarnos, en conclusión, a confesar humildemente nuestra ignorancia sobre la posible

F. Beltrán-J. de Hoz-J. Untermann, El tercer bronce de Botorrita (Contrebia Belaisca), Zaragoza, 1996, p. 147.

${ }^{8}$ Hispania y Marcial, p. 230.

${ }^{9}$ Es la opinión de Dolç, Hispania y Marcial, p. 222.

${ }^{10}$ Así Dolç, Hispania y Marcial, p. 216.

11 "El nombre más parece greco-latino que céltico", dice A. Tovar, Iberische Landeskunde, Segunda parte, Baden-Baden, 1989, III, p. 418.

12 A. Tovar, Estudios sobre las primitivas lenguas hispánicas, Buenos Aires, 1949, pp. 51-52.

${ }^{13}$ Cf. sobre todo "CIL II 4314 y Marcial", Emerita XXXVIII (1970), "Una nueva poesía de Marcial", Emerita, XL (1972) 475ss. La inscripción se conserva actualmente en el Museo Diocesano de Tarragona. Para una excelente y pormenorizada discusión de los argumentos de Piernavieja cf. ahora J. Gómez Pallarès, Poesia epigràfica latina als països catalanes. Edició $i$ commentar, Barcelona, 2002, p. 80ss. 
actividad de Marcial como poeta en Bílbilis, fuera del corpus canónico de su obra.

Acabado su gran siglo, Hispania se difumina, y con ella Marcial. Sólo en el s. IV vuelven a aparecer en el suelo ibérico personalidades egregias, pero todas ellas poseídas de un fervoroso cristianismo poco compatible con la obra del genial epigramatista. El último gran poeta hispano, Prudencio, tan encendido cantor de los mártires como implacable fustigador del paganismo, se empapó de épica y de sátira, sin interesarse por la elegante hiel y cínica despreocupación de Marcial. Las escasas coincidencias que aparecen en sus versos (Cath. V 118 raraque cinnama = Mart. IV 13, 3 rara... cinnama; VI 22 Lex haec data est caducis $=$ I 35, 10 Lex haec carminibus data iocosis) no son más que eso: coincidencias ${ }^{14}$.

\section{Marcial en la Edad Media}

Durante los siglos V y VI Hispania volvió a sumirse en un marasmo prolongado, mientras en el África vándala, a pesar de todos los pesares, florecía la cultura y hasta hacían pinitos los poetas áulicos con no despreciable fruto, pinitos recogido después en la llamada Antología latina ${ }^{15}$. El reino visigodo, en cambio, no levantó cabeza hasta finales del s. VI, pero entonces la remontada fue espectacular.

Desde A. Riese los filólogos han reconocido imitaciones de Marcial en los epigramas que compuso San Isidoro para la Biblioteca de la Iglesia hispalense. Últimamente, J. Mª Sánchez Martín ${ }^{16}$ ha elaborado un elenco completísimo de paralelismos, incluyendo entre ellos por mor de

${ }^{14}$ A. M. Palmer, Prudentius on the Martyrs, Oxford, 1989, p. 217 señala que Prudencio coincide con Marcial al calificar a Tárraco como arx; pero es una correspondencia banal que aparece, como señala la misma autora, en otros poetas.

${ }^{15} \mathrm{Cf}$. sobre este período y el siguiente la útil visión de conjunto de Günter Bernt, Das lateinische Epigramm im Übergang von der Spätantike zum frühen Mittelalter, Münchener Beiträge zur Mediävistik und Renaissance-Forschung 2., München, 1968.

16 Isidori Hispalensis uersus, Turnhout, 2000, p. 18ss. La disposición del poema XXVII, lacunoso, me parece equivocada: fieri ha de ser final de pentámetro; el hexámetro siguiente, corrupto, reza así: quod uult scriba magis nosset eo oportet, amice. 
exhaustividad algunos giros que pueden tener otro origen: así ocurre a mi juicio con ille ego (IV 1), que deriva del famoso ille ego qui de la Vita Vergiliana y es comunísimo en la poesía sepulcral, o con Desine (XI 9) en comienzo de hexámetro, también muy virgiliano (cf. Ecl. VIII 61, IX 66, Aen. IV 360, VI 376). La poesía isidoriana, en definitiva, resulta ser un centón de reminiscencias clásicas. Baste un ejemplo: el dístico (II 1-2)

Sunt hic plura sacra, sunt hic mundialia plura.

Ex his si qua placent carmina tolle, lege.

es eco de Mart. I 17 Sunt bona, sunt quaedam mediocria, sunt mala plura, de VI 61, 4 carmina nostra placent y II 29, 10 splenia tolle, legas, aunque en el último caso el influjo del Tolle lege agustiniano es evidente.

$\mathrm{Si}$ el conocimiento de Marcial es innegable en la poesía isidoriana, sorprende, sin embargo, el poco uso que se hace de los epigramas en las Etimologías. Una simple ojeada al índice de loci citati de Lindsay basta para concluir que la mayor parte de las citas de Marcial procede de los libros XIII y XIV, es decir, de los Xenia y Apophoreta: de ahí vienen palabras raras como aphronitrum (16 2, 8 = Mart. 14, 58), dama (12 1, $22=$ Mart. 13, 94), ficedula $(12$ 7, $73=$ Mart. 13, 49), melimela $(17$ 7, $5=$ Mart. 13, 24), phasianus $(127,49=$ Mart. 13, 72) o psittacus $(12$ 7, $24=$ Mart. 14, 73). Pero es más: sólo tres veces trae a colación San Isidoro al poeta por su nombre (12 1, 22;13 21, 34; 20 2, 13); lo normal es que la mención venga precedida de un vago quidam $(162,8 ; 177,5 ; 46 ; 48 ; 2010,3)$, o de un no menos vago uersiculo ueteri illo $(127,73)$, uetus distichon illud $(127$, 49; cf. 20 4, 13) o simplemente illud (12 7, 24; 46; 20 14, 4). Es evidente, a mi entender, el metropolitano está citando de segunda mano, tomando sus versos de algún repertorio hoy perdido como el que sirvió de fuente común a su tratamiento de los barcos en Etym. 19 1, 9ss. y a la representación naval en el mosaico de Althiburus (CIL VIII 27790)17. No acierto a explicarme el chocante contraste que existe entre los versos y las Etimologías en lo que al conocimiento de Marcial se refiere. Quizá los versos sean una contrahechura de otros poemas más antiguos: no deja de ser llamativo que precisamente en los epigramas más recientes (los dedicados p.e. a San Gregorio y a San Leandro) las huellas de Marcial brillen por su total ausencia.

${ }^{17}$ Cf. M. Rodríguez Pantoja, Habis VI (1975) 135ss. 
En este contexto de nebulosa marcialesca nos queda por tratar de otro posible recuerdo del poeta de Bílbilis en la antigua Híspalis: el epitafio del obispo Honorato (IHC 65: ICERV 273, 10) ${ }^{18}$, que reza así:

iamque nouem lustris gaudens dum uita maneret, spiritus astra petit, corpus in urna iacet.

Obiit idem pontifex sub d. pridie idus Nouembres era DCLXXVIIII $[=$ a. 641]. In honore uixit annos quinque menses VI. Non timet ostiles iam lapis ste minas.

La última frase (¿quién lo diría?) es un pentámetro tomado de Mart. VI 76, 4, con una grafía hipercorrecta ste por iste. ¿A qué hostes pudo referirse el autor del epitafio? A lo que sabemos, el reino visigodo estaba en paz, y no me parece indicado buscar tres pies al gato interpretando hostis como una alusión a la "estantigua" o hostis antiqua, esto es, el diablo, sempiterno perturbador del linaje humano (pero cf. Isid. Vers. 4, 8: tutus ab hoste fui). La referencia erudita, a mi juicio, está tomada de otra lauda sepulcral; y me tienta la idea de suponer que el verso de Marcial se insertó originariamente en algún epitafio de África, cuando la persecución vándala contra el catolicismo se hallaba en plena virulencia y cuando, al mismo tiempo, poetas como Luxorio componían epigramas a imitación de los antiguos. Tenemos un ejemplo similar: otro dístico de Marcial (I 40,2) acabó siendo embutido en dos inscripciones cristianas, una de África, del s. VI (CLE 2064), y otra de Pèbre ${ }^{19}$. Y es de notar que en los tres casos que nos ocupan se emplearon los versos antiguos con una clara intención apotropaica ${ }^{20}$; como podría haber ocurrido también en la inscripción de Honorato.

${ }^{18} \mathrm{La}$ autenticidad de la inscripción, puesta malhadadamente en duda por H. Gimeno y M. Miró ("Carmina para Honorato, obispo de Híspalis; la polémica inscripción del sucesor de San Isidoro", AespA [1999] 241ss.), ha sido defendida con buenos argumentos por C. Fernández y R. Carande, "Dos poemas epigráficos dedicados a Honorato: Nuevo estudio de IHC 65 y 363", Laboratorio de Arte, 15 (2002) 13ss. El primero en advertir la copia de Marcial fue Hübner (IHC 65: "quod neminem antea observasse miror").

19 Cf. P. Howell, A Commentary on Book One of the Epigrams of Martial, Londres, 1980, p. 191.

${ }^{20}$ Es probable que Marcial circulase en pequeños florilegios debidamente expurgados. Sólo así se comprende que, como señaló K. Weyman (cf. Bernt, Das 
El mejor poeta de la época visigoda, el humilde San Eugenio ${ }^{21}$, metropolitano de Toledo, tan propenso a la queja y al lamento, testigo estremecido de los estragos causados por la vejez, buscó su inspiración en el africano Draconcio y en otros autores tardíos. Se encuentran en él ciertas reminiscencias de Persio, pero sólo en el prefacio (las palabras rancidulum o sanna, p.e. praef. 3 y 5; cf. App. 27 y 28), lo que indica muy probablemente que el conocimiento del satírico le viene a través de una fuente indirecta. Curiosamente, el verso Si barbae sanctum faciunt, nil sanctius hirco (LXXXIX 3) remonta a A.P. XI 430 y no a Mart. IV 53; IX 47; XI 84, 17-1822.

Total es la ausencia de Marcial en los ejemplos en verso que aduce el Ars atribuida a arzobispo Julián de Toledo, y eso que cita un pasaje de un poeta ya tan lejano como Juvenal, y precisamente de una de sus sátiras más feroces, la sexta (p. 138, 55 = Iuu. VI 70). Tampoco hay que esperar reminiscencias clásicas en la poesía de Valerio del Bierzo, muchas veces bárbara, en esos rebuscadísimos epitameron, palabreja en la que, antes que heptametrum ('composición de siete versos' en Eugenio de Toledo), como quería Díaz y Díaz ${ }^{23}$ (todavía Álbaro de Córdoba sabía cuál era el significado de Existica, título de uno de sus epigramas), propondría ver heptameron (i.e., é $\phi \theta \alpha \dot{\alpha} \mu \in \rho o v)$, siete poemas correspondientes a los siete días de la semana.

La dominación árabe puso dramático fin a la cultura visigoda. Durante mucho tiempo, ni en la Hispania cristiana ni en al-Ándalus se escucharon las voces de los poetas clásicos latinos. San Eulogio, como es sabido, tuvo que viajar a la Marca Hispánica para hacerse con códices: al parecer, Virgilio era desconocido en la Córdoba de comienzos del s. IX.

lateinische Epigramm, p. 97 n. 27), Avito remedase un verso obscenísimo de Marcial (carm. IV 499 Inter se tumidos gaudet committere fluctus = Mart. I 90, 7 Inter se geminos audes committere cunnos). Por otra parte, y como es sabido, Ausonio (28 4, 5ss.) citó a Marcial como Plinio, Rabano como Calpurnio en su Gramática; este último manejó el florilegio de Marcial conservado en el Leidensis Voss. Q 86, del s. IX (cf. Bernt, ibidem, p. 242 n. 27.

${ }^{21}$ Utilizo la edición de Vollmer (MGH, Auct. Ant. XIV).

${ }^{22}$ Cf. las imitaciones de Tomás Moro (The Complete Works of St. Thomas More, III.2, Yale-New Haven-Londres, 1984, $\mathrm{n}^{\mathrm{o}}$ 157, p. 200) y de B. L. de Argensola, Rimas, 54 (Ed. de J. M. Blecua, Clás. Cast., I, p.164)), XXX (II, p.198).

${ }^{23}$ Anecdota Wisigothica. I, Salamanca, 1958, p. 89ss. 
Un inventario de manuscritos nos da a conocer los libros que tenía un monasterio, probablemente de Córdoba, en el 882: los únicos poetas paganos que se leen en ese catálogo son Virgilio, Ovidio y Prudencio ${ }^{24}$; de Marcial, ni rastro. Un poema de Álbaro de Córdoba, en el que se describe al pavo real, contiene un hemistiquio (IV 11: mire dum explicat alas) que parece un claro eco de Marcial (XIII 70: gemmantis explicat alas); pero otra vez me temo que nos hallemos ante un espejismo: la poesía ha de remontar a un modelo anterior, y este modelo es evidente que existió para la lista de ruidos que emiten los animales: el poema XLI de San Eugenio (Ant. Lat. 730, cf. Aus. 76). En cuanto a la literatura de la Hispania cristiana, es demasiado magra para buscar en ella reminiscencias de nuestro poeta. Las hagiografías y los secos anales de la Reconquista no son el campo abonado para que florezca el epigrama. Ni siquiera en el Renacimiento de los s. XII y XIII se percibe huella alguna del bilbilitano, y eso que entonces comenzó a sentirse la urgente necesidad de buscar españoles ilustres en el pasado para colmar el vacío cultural del presente. De todas maneras no hay que olvidar que de Hispania proceden dos códices importantes para la epigramática: uno, en uncial, de la Antología Latina (el famoso Salmasiano, hoy Parisinus 10318) y otro de Ausonio (Leidensis, Vossianus 111 + Parisinus BN Lat. 5387). Y hasta se ha pretendido hablar de una Antología Hispana, conservada en el códice parisino citado y en el matritense BN 10029: una colección de epigramas funerarios y conmemorativos que nada tienen que ver con Marcial.

\section{Las apologías de la cultura española: Marcial, español}

El más permanente contacto con el extranjero, gracias a los peregrinos venidos por el camino francés y a los españoles salidos a estudiar a París, puso de relieve carencias dolorosas en la cultura ibérica y avivó un cierto patriotismo de campanario. Inauguró la larga serie de apologías de la ciencia española la Crónica de D. Lucas, obispo de Túy. Es muy significativo, en consecuencia, que en ella se pase de largo sobre nuestro poeta, aunque no ha de escandalizarnos tal ignorancia: habían silenciado el nombre del epigramatista las fuentes de que se había servido el prelado para narrar el período clásico, la Historia de Eusebio y la Crónica de

${ }^{24}$ Cf. mi Corpus scriptorum Muzarabicorum, Madrid, 1973, II, pp. 707-08. 
San Jerónimo (este último había citado, en cambio, a Quintiliano y a Plinio el Joven [p.161m y 165c Schoene]); era una fatídica laguna que no podían colmar sus modelos medievales, ni su querido San Isidoro ni su no menos querido Pedro Coméstor. Don Lucas sabe, sí, que Séneca y Lucano eran oriundos de Hispania ${ }^{25}$, pero los únicos Marciales que conoce son cristianos: el mártir cordobés y un discípulo de los apóstoles oriundo de Limoges ${ }^{26}$.

El otro gran cronista del s. XIII, D. Rodrigo Jiménez de Rada, peregrino en muchos países y conocedor de varias lenguas, o bien desconoció la existencia del bilbilitano o bien no tuvo ocasión de sacarla a relucir. Lo más probable es la primera alternativa. En efecto, también para el panegirista de D. Rodrigo, Diego García de Campos, Marcial fue una abstrusa entelequia, un nombre más perdido en una lista absurda de filósofos, que el canciller real enumeró en cuidada serie paralelística y buscando la aliteración y la paronomasia: Parmenides et Parmenio, Meonides et Meonidus, Marcialis et Marcianus ${ }^{27}$.

Tampoco llegó a manejar los Epigrammata un monarca tan amigo de la cultura como Alfonso X, acucioso colector de todo lo hispano: no hubiera dejado de citarlos como gloria autóctona, de haberlos conocido. Esa ignorancia es muy llamativa, pues el rey fue muy aficionado a la poesía latina; e incluso incluyó en su Crónica general de España ${ }^{28}$ un epigrama anónimo, atribuyéndolo erróneamente a Julio César ${ }^{29}$, en el que se hablaba del niño tracio ahogado en las aguas heladas del Hebro (parecido en el tema a Mart. III 19 y IV 18); río que, evidentemente, no tiene nada que ver con el Ebro salvo la engañosa hominimia (avivada por la pérdida de la $h$-inicial; pero la adición u omisión de la aspiración era un pecadillo menor en aquellos tiempos).

Así las cosas, la primera alusión a Marcial en nuestra historiografía, a lo que sé, es la que aparece en el De praeconiis Hispaniae del franciscano Juan Gil de Zamora (ca.1240-1330). En el apartado consagrado a los

${ }^{25}$ Cf. Praef. p. 7, 82 y I 114, p. 105, 28 Falque respectivamente.

26 Praef. p. 6, 14 Falque.

${ }^{27}$ Planeta, p. 171, 2 (ed. Manuel Alonso, Madrid, 1943).

${ }^{28}$ Cap. 118 (I, p. 94 b Menéndez Pidal).

29 Así todavía Baltasar Gracián, Agudeza y arte de ingenio en que se explican todos los modos y diferencias de conceptos en Obras de Lorenzo (sic) Gracián, Barcelona, 1669, Discurso I, p. 1. 
hombres ilustres nacidos en Hispania, el fraile enumera a dos poetas oriundos de Bílbilis, Marcial y Liciniano, sin privarse de mencionar asimismo a Deciano de Mérida ${ }^{30}$. Incluso se encuentra intercalado un hexámetro de Marcial en las Alabanzas e historia de Zamora ${ }^{31}$ : accipe Gallicis quidquid fodit Asturianus (X 17, 3); pero el cambio introducido (Asturianus por Astur in aruis), que estropea el sentido, parece indicar que se trata de una cita de segunda mano.

Gracias a fray Juan Gil, pues, el nombre del epigramatista se incorporó finalmente al catálogo de españoles ilustres, ese catálogo necesario para prestar empaque cultural a los reinos de la Península Ibérica. La misma retahíla de nombres enumeró Bernardino de Carvajal al pronunciar el discurso de obediencia al Papa Alejandro VI el 19 de junio de 1493, cuando, una vez destacada la conformidad de las dos penínsulas, Italia y España, en el paganismo y en la cristiandad (las dos recibieron el nombre de Hesperia), el orador exaltó la inteligencia de los españoles citando una lista de antepasados gloriosos en la que figuraba Marcial en tercer lugar ${ }^{32}$; claro que Carvajal, a fuer de buen español, alardeaba de hablar más con hechos que con palabras: en definitiva España, por su lucha contra el Islam, era la provincia más benemérita de la religión cristiana.

Fue así como los humanistas españoles, imitando a los italianos, contribuyeron decisivamente a forjar a finales del s. XV la idea de una prolongación mítica de la Península Ibérica a través de los siglos, tendiendo un puente directo entre la España de su tiempo y la Hispania romana. Quien más contribuyó a difundir esta especie fue Rodrigo Sánchez de Arévalo, obispo de Palencia y castellano del castillo de Santángelo, que publicó en Roma su muy interesante Compendiosa historia

${ }^{30} \mathrm{~J}$. Pérez-Embid Wamba, Hagiología y sociedad en la España medieval. Castilla y León (siglos XI-XIII), Huelva, 2002, p. 345.

31 J. Costas Rodríguez, Juan Gil, Alabanzas e historia de Zamora, Zamora, 1994, p. 39.

32 De los antiguos mencionó a Séneca, Lucano, Marcial, Silio Itálico, Quintiliano, Trogo, Pomponio Mela, Lucio Floro y Orosio (Oratio super praestanda solenni oboedientia Sanctissimo D.N. Alexandro Papae.VI. ex parte Christianissimorum dominorum Fernandi et Helisabe Regis et Reginae habita Romae in consistorio publico per R. Patrem dominum Bernardinum Carvaial, episcopum Carthaginensem, die Mercurii xix Junii salutis Christianae MCCCCXCIII). 
Hispana en fecha temprana para los anales de la imprenta, pero no anterior a 1470. En efecto, ampliando el consabido esquema de las laudes Hispaniae, el capítulo cuarto del libro primero está dedicado a ensalzar las virtudes de los españoles: agudeza de ingenio (debida a la salubridad del suelo), austeridad y sobriedad, belicosidad, religiosidad, valor, lealtad, amistad, humanidad, etc. Arévalo, para no menguar la gloria de sus paisanos con alabanzas domésticas, trajo a colación en prueba de sus asertos pasajes de Justino, Vegecio, Livio, Eutropio, Justino, Valerio Máximo y otros autores clásicos. Como se ve, en Sánchez de Arévalo está ya firmemente asentado un cuerpo de doctrina que va a ejercer profunda influencia en la historiografía posterior: la creencia en la inmutabilidad de ciertos caracteres que habrían preservado intactos los españoles a través de los siglos. Este capítulo de Rodrigo Sánchez de Arévalo nos recuerda de inmediato a determinadas partes de la brillantísima Introducción que puso Menéndez Pidal a la Historia de España por él dirigida; asimismo, la observación del obispo sobre el visceral rechazo a la herejía que caracteriza a Hispania ("nouitatum fidei inscia est atque impatiens") es, en definitiva, la idea motriz que inspira a la Historia de los heterodoxos de Menéndez Pelayo. Ello no es óbice para que, según Sánchez de Arévalo, la Historia de España propiamente dicha comenzara con Atanarico: Enrique IV sería, pues, el 71 sucesor en línea directa de Atanarico y el 44 de Pelayo. Volviendo a nuestro propósito, es claro que para el obispo todos los escritores hispanos fueron españoles: una vez dice "noster Lucius Seneca in Tragediis" II (de Roderico); mas, sorprendentemente, no encuentro en su obra historiográfica eco alguno del epigramatista ${ }^{33}$.

Marcial, español. Nadie puso en duda esa tan clara como engañosa equivalencia: ni en los primeros albores del Humanismo, ni durante el Renacimiento, ni en el Siglo de Oro. En 1485 un canónigo sevillano, Pedro de León, citó un pentámetro de "nuestro" Marcial $(\mathrm{I} 3,8)$ en una admirativa carta a Rodrigo de Santaella, deseándole que no le ocurriera al Memoriale pontificum el manteo que el epigramatista auguraba para su

${ }^{33}$ Lo más parecido a una cita se encuentra en I 3: "plures mundi prouintias ferro et calibe ditat, nec ullum apud Hispanum telum probatur quod non aut Birbili fluuio aut calibe tingatur; unde etiam calibes huius fluuii finitimi appellati ferro caeteris praestare dicuntur". Evidentemente, es una referencia lejana -y encima despistada- a Mart. IV 55, 11ss. 
segundo libellus $^{34}$. Por 1495 otro prebendado de Sevilla, el doctor Cisneros, reseñó entre las glorias hispanas a "Valerio Marçial, natural de la çibdad de Bílbilis, que era çerca de Medina Çeli, e fue escriptor de epigramas muy acutíssimo" 35 . Sorprende, en consecuencia, que Gonzalo García de Santa María dejara pasar en 1493 una ocasión óptima de enorgullecerse de un paisano cuando tradujo al romance uno de sus aforismos más famosos ${ }^{36}$.

En la Sylva de origine et laudibus poeseos, dedicada al duque de Gandía D. Juan de Borja e impresa en 1525, Juan Ángel González (+ 1548), profesor de Poética en la Universidad de Valencia, tejió con laboriosidad una historia de la poesía greco-latina en la que se refirió a Marcial como noster vates, adjetivo este de noster que de manera sorprendente regateó a Séneca y a Lucano; el bilbilitano y Silio Itálico eran los únicos uiri docti citados de la Edad de Plata ("nec foelix nec multum fertilis aetas"):

Hinc etiam nostri resonant epigrammata uatis

Qui lepidos uafro condidit ore sales.

Marcial debió de ser poeta de su agrado, pues para excusar la posible rudeza de su Musa, Juan Ángel imprimió como colofón de la Silva un dístico de Marcial (I 17) que, como se recordará, ya había sido utilizado en los versos isidorianos ${ }^{37}$.

La doctrina hizo mella incluso en el extranjero. Una lista de celebridades muy semejante a la de Arévalo se encuentra, p.e., en la biografía que hizo Pablo Giovio de Antonio de Lebrija: a la invasión musulmana se debe el cortocircuito de la cultura, pues de la fertilidad de España en

34 J. Hazañas, Rodrigo Fernández de Santaella, Sevilla, 1909, p. 16, da una traducción del verso que es pura fantasía.

${ }^{35}$ Editado con facsímil por D. Ramos, Memorial de Zamora sobre las Indias, Granada, 1982.

${ }^{36}$ El Catón en latín y en romance, Zaragoza, 1494 (reimpr. facsimilar, Valencia, 1997, p. 9): "Por esso preguntado Marcial por un amigo suyo Flacco por qué no havía en el mundo entonce otro Virgilio respuso: 'Si hoviesse muchos Mecenas, no faltarían en el mundo muchos Virgilios' [VIII 55, 5]".

37 Vv. 317-18, cf. J. Alcina Rovira, Juan Ángel González y la "Silva de laudibus poeseos" (1525), Universidad Autónoma de Barcelona, 1978, p. 49 y 51, repectivamente. Ángel había citado ya a Marcial en su Tragitriumpho (ibidem, p. 14). 
preclaros ingenios daban buena fe Lucano, los Sénecas, Silio y Marcial ${ }^{38}$. Mas la identificación del pasado con el presente acarreó también consecuencias negativas, como vamos a ver a continuación.

\section{El rechazo a Marcial, por español}

La apropiación de Marcial por parte de los españoles -e Hispanus poeta lo llamó no sin razón Tomás Moro ${ }^{39}$ - tuvo un efecto inmediato en la valoración de los escritores hispanorromanos fuera de España, y ello por razones políticas muy claras. En efecto, a partir de los Reyes Católicos no sólo Aragón, sino también Castilla intervinieron muy activamente en la política italiana. Esta presencia española en Italia dejó un poso evidente, para alabanza o para escarnio, en las obras de los humanistas de la época que, como hombres que eran, se dejaron influir en sus juicios por sus filias y sus fobias. Comencemos a pasar revista por el reino de Nápoles, el primero en sufrir la dominación ibérica.

Una figura muy atractiva, un grandísimo poeta, nos sale de inmediato al paso: Juan Joviano Pontano (1426-1503). En la obra de Pontano bullen los españoles: unas veces aparecen como hombres vanos y grandilocuentes (el soldado fanfarrón de inacabables apellidos), otras sientan plaza de agudos y cortesanos (Rodrigo de Sevilla), otras brillan por su lascivia y afán de placeres (de lujuriosos califica en más de una ocasión a todos los valencianos, jóvenes y viejos; una de sus prostitutas procede de Valencia). De este asiduo trato con los españoles, que no hubo de ser siempre agradable y placentero $-\mathrm{y}$ podemos barruntar lo que Pontano

${ }^{38}$ Elogia doctorum virorum ab avorum memoria publicatis ingenii monumentis illustrium, Basilea, 1561, nํㅜㄴ 14 p. 148: "Hispania... maximorum ingeniorum ferax, si Lucani, Senecarum, Silij, Martialisque memoria recolatur, ut hîc Auerroem in Arabica lingua sapientiae lumine clarissimum omittamus" (es notable la frase en Giovio, tan antiespañol en política [de ahí la pulla de Domingo Andrés en su epigrama XIII, p. 69 Maestre]). De la excusa de la Reconquista se sirvió también Juan Luis de la Cerda cuando calificó a los españoles coetáneos de Juan de Mena como "rudes, ut occupatos in distinguendis [¿errata por destringendis?] gladiis et bellorum discursibus aduersùs Mauros" ( $P$. Virgilii Maronis posteriores sex libri Aeneidos, Lyon, 1619, p. 122 b).

${ }^{39}$ The Complete Works of St. Thomas More, III.2, $\mathrm{n}^{\mathrm{o}}$ 241, 1 (p. 256). 
pensaba de ellos para su coleto por la negra opinión que merecieron los españoles a un discípulo de Sannazaro, A. S. Minturno40-, así como de juicios extremados como el expuesto por R. Sánchez de Arévalo, prendió también en Pontano la idea equivocada de que los españoles que él conocía eran como los hispanos de la época romana. De esta idea y de esta equiparación falsas surgió el juicio sobre Marcial que se expone en el libro tercero de su tratado De sermone, en el que incluyó un capítulo intitulado De Valerii Martialis Poetae dictis:

Valerio Marcial, artificiosísimo autor de epigramas, hace en ellos uso de la burla de suerte que más a menudo denigra que deleita, aunque de la mordacidad surja asimismo el propio deleite. Además, sus agudezas a veces tienen aguijones muy recónditos, a veces palabras que no sólo están privadas de gracia, sino que son muy obscenas y chocarreras o ampulosas y agrias sobremanera, vicio que es muy español. Pues aunque los españoles son muy amigos de las gracias, sin embargo, si observas a los hombres del común o de la plebe, te percatarás de que sus chanzas propenden no tanto al juego y al donaire cuanto a la mordacidad y que prefieren la invectiva y el escarnio a la risa y al placer nacido de la jovialidad, que es ternísimo en los hombres graciosos ${ }^{41}$.

${ }^{40}$ La floreciente cultura de Nápoles decayó, según Minturno (Antonii Sebastiani Minturni de poeta, ad Hectorem Pignatellum, Vibonensium ducem, libri sex, Venetiis, 1559, p. 435), por haberse impuesto en la ciudad la idea española de que era un deshonor para los nobles dedicarse a las letras ("tetra quaedam ac dira opinio eademque orta in extrema Occidentis barbaria", "barbara improbitate", "barbaries", "nefanda barbaries aliunde Neapolim inuecta", exclama irritado el italiano). Los "milites gloriosi" -así los llama Minturno (p. 437)- deberían por lo menos saber que sin escritura quedarían sepultadas en el olvido sus supuestas hazañas.

41 "Valerius Martialis artificiosissimus epigrammatum scriptor ita in iis quidem iocatus est, ut frequentius carpat quam delectet, tametsi e demorsione ipsa delectatio quoque paritur. Ad haec dictis eius partim occultissima quaedam insunt spicula, partim uerba quae non solum a faceto sint aliena, uerum aut oscena ipsa admodum scurriliaque aut maxime ampullosa et acida, quod quidem Hispanicum est. Nam etsi Hispani cum primis sunt facetiarum studiosi, tamen si populares respexeris ac plebeios eius gentis homines, inuenies eorum iocos non tam propendere in lusum ac delicias quam in submorsiones magisque spectare in inuectiuas et subsannationes quam in risum uoluptatemque e iucunditate conceptam, quae in facetis uiris tenerrima est". Utilizo la primera edición sin 
Marcial, en definitiva, posee a juicio de Pontano sal y fel, términos que van a tener mucha fortuna (recordemos, p.e., la distinción entre Catulo y Marcial que establece sobre estos términos la Poética de J. C. Escalígero); pero al gran napolitano, amante del término medio, no le gustan los extremos, de suerte que rechaza en gran parte la obra del epigramatista, igual que desecha como excesivos algunos chistes de Cicerón. Bien está esa temperancia. Lo que nos interesa por encima de todo en este juicio, sin embargo, es la identificación del poeta romano con los españoles de su tiempo, pues ello quiere decir que la valoración de Marcial dependerá, sin duda ninguna, del grado de aprecio o de antipatía que sienta el crítico en potencia hacia España. Y no deja de ser curioso que esta chocarrería que Pontano adjudicaba a los españoles la haya considerado también como muy característica de nuestra patria C. Sánchez Albornoz, que ha consagrado un buen número de páginas a destacar "lo rahez hispánico" en la literatura ${ }^{42}$, no siempre a decir verdad con mucho tino. Pero no menos desatinadamente F. C. Sáinz de Robles, sobre la pauta del tan traído y llevado senequismo ibérico, llegó a postular un "marcialismo español"43.

Prosigamos. Rival cuando no enemiga de Aragón y después de España fue la Señoría de Venecia, por lo que no es de extrañar que esta rivalidad política se reflejase asimismo en la crítica literaria. El primer humanista veneciano en mostrar rechazo a Marcial fue el gran historiador Marco Antonio Sabélico, según se dice ${ }^{44}$. Pero en la monumental obra

foliar: Ioannis Iouiani Pontani opera, Nápoles, 1509 (excussum opus Neapoli per Sigismundum Mayr Alemanum, summae diligentiae artificem, mense Augusto MDVIIII, asistente (ut in aliis) P. Summontio. Ac fideliter omnia ex archetypis Pontani ipsius manu scriptis, quae deinde Summontius Neapoli in aedi diui Dominici seruanda curauit). Recordó muy oportunamente el juicio de Pontano B. Croce, España en la vida italiana durante el Renacimiento, Madrid, pp. 73-74.

42 España, un enigma histórico, Buenos Aires, 1956, I, p. 127 y 128 y, sobre todo, 226ss.

${ }^{43}$ El epigrama español, del s. I al XX, Madrid, 1946, p. 24ss. Cf. en contra J. Nowicki, Die Epigrammstheorie in Spanien von 16. bis 18. Jahrhundert. Eine Vorbereit zur Geschichte der Epigrammatik, Wiesbaden, 1974, p. 2, 29 n. 15a (debo el conocimiento de este libro al Prof. D. López-Cañete, a quien expreso mi más profundo agradecimiento).

${ }^{44}$ Así lo recoge entre otros juicios sobre Marcial el librito M. Val. Martialis ex Museo Petri Scriverii, Amsterdam, apud Ioannem Iansonium, 1621. 
de Sabélico no soy capaz de encontrar ninguna crítica adversa al epigramatista, antes al contrario ${ }^{45}$.

De su maestro Sabélico, si es verdad que sintió esa aversión por el bilbilitano, heredó los gustos literarios Andrés Navagero (1483- Blois 1529). Refiere Pablo Giovio ${ }^{46}$ que fue tal la ojeriza que Navagero mostró a Marcial que todos los años, en el día consagrado a las Musas, quemaba como deshonesta su obra, colmándola de maldiciones e improperios. Para declararse en contra de Marcial bastaba con ser admirador fanático de Catulo, y Navagero lo era en grado sumo: así lo demuestran sus hendecasílabos muy catulianos dirigidos a Bembo y Canale (XXX [p. 208]) o el poema dedicado a la muerte del perrito Borghetto, que evoca el poema del passer (p. 219, un ejemplo excelente de imitatio a juicio de B. Ricci ${ }^{47}$ ). Ahora bien, también en este desapego extremoso puede verse una cierta soterrada venganza contra la dominación española. Y que Navagero se dolía de ver el suelo italiano sometido a una potencia extranjera lo demuestra claramente el discurso fúnebre pronunciado a la muerte de Bartolomé Liviano. Ensalzando sus dotes de general y lamentando que Italia hubiese perdido la disciplina, esa disciplina que había llevado a los romanos a la conquista del mundo, Navagero se lamentó de la flaqueza de los soldados de su patria; si Liviano hubiese sido seguido adecuadamente por su ejército, "jam tum ab Hispanorum jugo nostras has regiones

${ }^{45}$ VII 4 (Venecia, 1498, I, f. 427v) "Nec Iuuenalis Aquini ortus parum per id tempus meruit in Satyra, nec Valerius Martialis minus epigrammate. Nullus poetarum fuit urbanior, uterque alteri Romae notus. In Hispania hic, ubi Bilbilim habuit patriam, ille in Aegypto periit". Del testimonio de Marcial se sirve precisamente Sabélico para demostrar que Quintiliano no pudo nacer en Hispania: "numquam Hispaniam tali partu fraudasset" (ibidem [I, f. 426r]).

46 Elogia doctorum virorum ab avorum memoria publicatis ingenii monumentis illustrium, Basilea, 1561, no 78, pp. 180-81: "Eodem quoque praestanti iudicio, quum Epigrammata lepidissimè scriberet, non salsis aculeatisque finibus, sed tenera illa et praedulci prisca suauitate claudebat, adeo Martiali seuerus hostis, ut quotannis stato die Musis dicato multa eius uolumina tanquam impura cum execratione Vulcano dicarentur". Cf. J. Nowicki, Die Epigrammstheorie, p. 57 y sobre todo la larga n. 91.

${ }^{47}$ De imitatione libri tres ad Alfonsum Atestium Principem, alumnum suum, París, 1557, f. 49v ss. El tema del passer lo tocó también Álvar Gómez de Castro en su poema XVIII, pero introduciendo otra variante erótica: la del palomo cojo. 
liberasset"48: quien habla de "yugo de los españoles" mal podía estar contento de verse sometido a España. Curiosamente, no se trasluce animadversión alguna a Marcial en su Viaggio in Ispagna, pues se refirió a la cuna del poeta sin formular un juicio de valor: "Il rio del Tajo nasce in Aragon, non molto lontano da Calatajut, dove dicone che era Bilbilis, patria di Marziale ${ }^{49 \prime}$.

De la misma opinión crítica fue Rafael Maffei (Volterra 1451-Roma 1522), conocido comúnmente por el lugar de su nacimiento como Rafael Volaterrano, autor de una muy leída y voluminosa enciclopedia: a su juicio, el libro de los Epigramas era totalmente repudiable, pues ni aprovechaba a la elegancia latina ni a las costumbres ${ }^{50}$. Mas conviene observar que también Maffei tenía motivos justificados para sentir ojeriza hacia los españoles, pues le había tocado vivir en Roma bajo la ominosa férula de los Borja, cuando la Ciudad Eterna se había llenado de soldados, matasietes y sicarios venidos de la Península Ibérica; los desafueros del Papa y de su hijo César le hacían añorar los buenos ejemplos que habían dado otrora otros gobernantes oriundos de Hispania como Dámaso y Trajano.

Idéntica recusación de Marcial hizo en sus Disticha Miguel Verino (1469-1487), que consideró los epigramas perniciosos para la moral, aun reconociendo su belleza ${ }^{51}$.

Sospecho que tampoco le tuvo mucha simpatía al epigramatista Rómulo Amaseo, profesor en Bolonia, a juzgar por la prevención con que lo miraron sus alumnos. Discípulo suyo fue Bartolomé Ricci (1490-1569), que consagró un libro a tratar precisamente de los modelos a imitar por el aprendiz de humanista: De imitatione libri tres (Venecia, 1541)52. A su juicio, los dos autores principales de la Latinidad son Cicerón y Virgilio,

48 Oratio habita in funere Bartholomaei Liviani (en Andreae Naugerii patricii Veneti oratoris et poetae clarissimi opera omnia, Padua, 1718, p. 10; sobre la disciplina romana cf. pp. 16-17).

4921, p. 351 = carta segunda a Ramusio (p. 301).

50 "Reliquit Epigrammatum librum omnino reijciendum, quippe qui neque elegantiae Latinae neque moribus prosit" (Commentariorum urbanorum, libr. XVII; utilizo la edición de S. Gryphius en Lyon, 1552, cc. 514-15).

51 "Carmina sint, fateor, pulcherrima vatis Iberi / At mores faciunt non tamen illa bonos".

52 Utilizo la edición de París, 1557, ya citada. Sobre su maestro Amaseo cf. f. 42r. Ricci también respetó mucho la autoridad de Navagero (f. $21 \mathrm{v}, 32 \mathrm{v}$ ). 
"duo Latinae linguae splendidissima lumina" (f.11r); en cuanto a Séneca, su estilo no fluye siempre con la debida pureza $^{53}$. ¿Qué tipo de epigrama debe tener ante los ojos el poeta novel? Unos alaban a Catulo, otros, con menos razón, a Marcial, señala el preceptista; para gran sorpresa nuestra, el mejor escritor en este género es, a su juicio, el autor de los Priapea ${ }^{54}$, quizá porque la Vita Vergiliana de Donato los había atribuido a Virgilio. El rechazo a Marcial, pues, se hace hasta cierto punto extensivo a Catulo, al parecer sin más motivos que los puramente estéticos. Pero, ¿habrá que recordar el peso que tuvo en Bolonia el Colegio de los españoles fundado por el cardenal Albornoz, peso que engendró sin duda odios y escoceduras?55 "Il vantator spagnuol"56 no podía dejar de serlo, incluso con toga y birrete. Más ecuánime, pero tampoco muy favorable al bilbilitano se mostró Francisco Robortello (1516-1567), otro discípulo de Amaseo, que encontró "fríos" muchos de sus chistes ${ }^{57}$.

Un paso más en la depreciación de nuestro poeta dio Lilio Gregorio Giraldi, el infatigable y benemérito historiador de la literatura antigua. A su entender, los mejores modelos de epigramas se encuentran en Catulo y en los Priapea, de manera que el simple hecho de enjuiciar a

53 "Seneca non tam accusandus est, quod non perpetuo planè ac splendide Latine locutus sit, quàm etiam laudandus atque recipiendus, quod tragoediae formam, qui nobis commonstret, solus remanserit" (f. 19v).

54 "At quoniam ferè nemo est, qui, modo primas syllabas attigerit, non audeat aliquid in epigrammate iocari, ac perpauci mea quidem sententia ita scribant ut iterum legi possint, his quoque maxime prouidendum est, ut habeant quo recte imitando sese recipiant. Hanc autem palmam sunt qui Catullo constanter deferant, sed is quodam suo numero nimis delectari videtur, qui nae mihi quoque probatur, si sua sponte veniat... Longe maior eorum est numerus, quanto etiam ignarior, qui in hoc genere Martialem sequantur. De quibus nihil aliud dicam, quàm id eis facere sine riuali per me quidem maxime licere. Equidem illos soleo, quicunque ij fuere, qui cum Virgilio in obscaenum Deum tam erudite, tam eleganter lusere, ceteris eius generis scriptoribus facile anteferre. Quod unum Naugerius et vidit primus et omnium imitatus est optime" (ff. 29v-30r).

${ }^{55}$ En el Viaje de Turquía se dice que el Colegio es "cosa muy insigne y de toda la çibdad venerada, aunque más mal quieran a los españoles" (NBAE 2, p. 100 a).

${ }^{56}$ Ariosto, Orlando furioso, XII 44, 1.

${ }^{57}$ Francisci Robortelli Vtinensis in librum Aristotelis de Arte Poëtica explicationes, Basilea, 1555, p. 28 del apéndice: "Martialis quoque apte multis in locis, sed plerunque in iocis friget". 
Marcial parece causarle un serio problema de conciencia: "No puedo decir con facilidad hasta qué punto se le haya de imitar, pues veo ciertamente que no todos sus epigramas, ni siquiera la mayoría agrada a los cultos. Yo, por mi parte, si los más doctos me dieran permiso (pero, ¿qué me impide decir ahora con vosotros lo que siento?), yo, repito, elegiría de todo su libro algunas cosas, no muchas, dignas de ser leídas por los buenos, con las que formaría un librito no grande, por Hércules; el resto, como dice él mismo, lo dejaría para envolver caballas y esturiones"58. La idea de expurgar a Marcial no es nueva; me interesa resaltar, en cambio, que este supuesto embarazo a la hora de emitir un juicio no es sino una brillante argucia de Giraldi, que busca escudarse en la amistad para poder expresar sus más íntimos sentimientos. En efecto, la misma aparente resistencia a pronunciarse vuelve a hacer acto de presencia en el caso de Lucano, que para el humanista no es el segundo ni el tercer poeta después de Virgilio, sino el más cercano, pero a mucha distancia ("sed longo proximus interuallo" [cf. Verg. Aen. V 320]). Y sigue diciendo: "Si tenéis en algo mi opinión, Pico, y tú, Pisón, no me gustaría que os aficionaseis en demasía a su lectura, sino que querría incluso que os gloriaseis de lo que oí una vez gloriarse a un amigo mío, varón doctísimo, que daba las gracias a las Musas del cielo por no haber leído jamás de un tirón todo el poema de Lucano. Y si no fuera una temeridad, cosa sin embargo para mí imposible de hacer, y menos con vosotros, me atrevería a decir de Lucano lo que dijo Marco Tulio de unos poetas de Córdoba de su tiempo, que a su juicio sonaban un no sé qué graso y extranjero"59. Ya están aquí emparejados Marcial y Lucano, y los dos

58 Historiae poetarum tam Graecorum quam Latinorum dialogi decem, Basilea, 1545, Dialogus X, pp. 1098-99: "Cui quantum accedendum censeam, haud facilè dixerim. non certè eius omnia epigrammata, nec plurima quidem uideo doctis placere. Ego utique, si per doctiorum ueniam mihi liceret (sed tamen quid uetat me nunc uobiscum quod sentio dicere?), ego, inquam, ex toto eius libro quaedam, nec plurima seligerem, bonorum digna lectione, quibus libellum non hercule maximum conficerem; reliqua, quod et ipse ait, scombris et siluris inuolucra relinquerem". El juicio sobre los epigramas se encuentra en p. 1077: "plurima apud Catullum et in Priapeis, et in Valerio Martiale nonnulla".

${ }^{59}$ Ibidem, pp. 524-25: "Si quid uero, Pice, et tu, Piso, mihi tribuistis, uos non modo non nimium studiosos eius lectionis uelim, sed uos etiam ita gloriari cupio, id quod amicum meum, uirum doctissimum, aliquando gloriantem audiui, qui 
marcados con una tacha que los relega a un segundo o tercer plano; poco falta ya para lanzar un anatema general contra los escritores hispanorromanos.

Esta última y definitiva condena se produjo en Francia, la gran rival de España en el s. XVI. Los primeros preceptistas literarios franceses señalaron como maestro indiscutible del epigrama a Clemente Marot, que cultivó este género literario seguramente por consejo del gran humanista Etienne Dolet, su gran amigo ${ }^{60}$. Así, en su Art poëtique françoys (París, 1548) Tomás Sebillet se abstuvo de dictar normas: se limitó a ajustar la preceptiva del epigrama a la poesía de Marot, sin soñar siquiera con una posible imitación de los autores griegos o latinos. Fue J. du Bellay el primero en propugnar una vuelta a lo clásico, el primero que propuso como modelo a imitar a Marcial, y no a Marot. Este clasicismo de Du Bellay despertó muy fuertes críticas. Su principal y acerbo opositor, el principal del Colegio de la Trinidad, Bartolomé Aneau, arguyó airado en su Quintil Horatian que Marcial es un "poëte inegal, bien souvant froid, Espagnol, mal Romain et flateur, idololatre de Domitian, vicieux et abominable sotadic, meritant n'estre mis en lumiere que de flambe de feu" ${ }^{\prime \prime}$. Salta a la vista la fuente de sus juicios: la hoguera inquisitorial nos recuerda inmediatamente a Navagero, el calificativo de "froid" a Robortello. Mas de nuevo -y esto es lo que cumple destacar- se

Musis coelestibus gratias agebat, quod nunquam totum Lucani carmen semel perlegisset. Nisi enim temerarium sit, quod nihil tamen mihi, uobiscum praecipue, esse potest, illud ausim de Lucano affirmare quod M. Tullius de Cordubensibus suorum temporum poëtis, qui eos nescio quid pingue et peregrinum sonare putabat".

${ }^{60}$ Curiosamente, no encuentro una fuerte influencia de Marcial en la poesía de Marot. En el manuscrito de Chantilly (escrito en marzo de 1538) aparecen once poesías bajo el título "Epigrammes faictz a l'imitation de Martial", pero sólo fueron publicadas en la edición póstuma de 1547. Charles E. Kinch (La poésie satirique de Clément Marot, París, ¿1940?, p 83ss.) ha señalado las libertades que se permitió Marot al traducir a Marcial, haciendo por lo general paráfrasis muy libres del original y dándoles un sabor muy francés: así Sertorio (III 79) se convierte en un "Lymosin" (CLXXXII M.) y Cándido (III 26) en "Jehan Jehan" (CLIX M.).

${ }^{61} \mathrm{H}$. Chamard, ed. de J. Du Bellay, La defence et illustration de la langue francoyse, Paris, 1948, p. 111 n. 2 de la página anterior. 
insiste en que los defectos de Marcial se deben a una característica nacional: un español nunca puede ser un buen romano o, lo que es lo mismo, un hombre de bien.

La idea que Aneau no llegó a expresar del todo la perfiló de manera muy clara otro gran humanista francés, Marco Antonio Muret, en el prefacio a su edición de Catulo ${ }^{62}$. Sus palabras son terminantes: "Los poetas españoles sobre todo corrompieron la pureza de la lengua latina $y$, habiendo introducido un género de discurso hinchado y ampuloso, conforme a las costumbres de su pueblo, desviaron con su ejemplo a los demás de aquella recta y simple imitación de la naturaleza, en la que estriba la mayor alabanza de los poetas y a la que los anteriores se habían entregado con todo su empeño"63. La grandilocuencia que había reprochado Pontano a los españoles se transforma en una característica totalmente negativa, pues ya no es propia de un poeta aislado, sino de toda la nación en su conjunto: igual de reprobable es Lucano que Marcial, dado que ambos muestran el mismo brillo lleno de afeites, la misma belleza adulterada de la elocuencia ("fucatus ille splendor et adulterina eloquentiae species"). Entre Catulo y Marcial hay la misma diferencia que media entre los chistes de un juglar de la calle y las gracias cultas de un hombre libre, rociadas abundantemente con las sales de la urbanidad ("inter Martialis autem et Catulli scripta tantum interesse arbitrer, quantum inter dicta scurrae alicuius de trivio et inter liberales ingenui hominis iocos, multo urbanitatis aspersos sale") $)^{64}$. En definitiva, la decadencia de

62 Más en concreto, en la dedicatoria de Muret al veneciano Bernardino Loredan (Catullus et in eum commentarius M. Antonii Mureti, Venetiis, apud Paulum Manutium, 1554).

63 "Hispani poetae praecipue et Romani sermonis puritatem contaminarunt et, cum inflatum quoddam et tumidum et gentis suae moribus congruens inuexissent orationis genus, averterunt exemplo suo ceteros à recta illa et simplici, in qua praecipua poetarum sita laus est et in quam superiores omni studio incubuerant, imitatione naturae" (Dedicatoria de Muret al veneciano Bernardino Loredan publicada en Catullus et in eum commentarius M. Antonii Mureti, edición citada).

${ }^{64}$ En el comentario volvió a insistir sobre la falta de sensibilidad estética de Marcial, que había antepuesto Arruncio Estela a Catulo: "sed ego Martialem (dicam libere, quod sentio) valde bonum harum rerum aestimatorem fuisse non puto" (ibidem, f. 4v). 
la Literatura latina (la corrupción de la elocuencia) se debe al auge y predominio de los españoles en un período crucial del Imperio romano. ¿Puede pensarse en mayor utilización política de la Antigüedad clásica? No maravilla que el juicio de Muret encontrase seguidores, que repitieron tal vez de manera inconsciente la misma cantilena, preludio de la gran polémica que estalló dos siglos después entre Tiraboschi y los jesuitas expulsos ${ }^{65}$ : todavía en el s. XIX un historiador de la literatura italiana, D'Ancona, atribuyó al genio de la raza española "un no sé qué de ampuloso y de hinchado"66.

En el s. XVII fue Holanda la rival más encarnizada de España. No sorprende, pues, que otro gran filólogo y gran jurista, Hugo Grocio, condenase tajantemente a Marcial -y con él a todos los españoles-, por ser un poeta en cuyos versos "saepe sola obscoenitas epigramma facit. Hispanis relinquamus hanc scabiem"67. La roña, para los españoles.

Afortunadamente, no todos los humanistas ni los reformadores pensaron así ni su odio a lo español alcanzó cotas tan ridículas. Basten dos ejemplos. Teodoro Beza, en su Ad Musas iocus, sacrificó con donaire a las Musas una polilla que había devorado sus libros, entre los que se encontraban sus tres poetas latinos preferidos, Virgilio, Catulo y Marcial:

Pene tu mihi passerem Catulli,

Pene tu mihi Lesbiam abstulisti.

Nunc certe meus ille Martialis

Ima ad uiscera rosus usque languet

Et quaerit medicum suum Tryphonem ${ }^{68}$.

${ }^{65}$ Cf. mi estudio sobre"La Literatura hispanorromana: historia de un mito" en M. Almagro-Gorbea-J. M. Álvarez Martínez (eds.), Hispania. El legado de Roma, Zaragoza, Ministerio de Educación y Cultura, 1998, pp. 373-81. J. L. Teodoro Peris, "Una polémica sobre la vigencia de la lengua latina a finales del siglo XVIII: aspectos de la querella entre Tomás Serrano y Clemente Vanneti", en A. M $\mathbf{M}^{\mathrm{a}}$. Aldama, F. del Barrio, A. Espigares (eds.), Noua et uetera. Nuevos horizontes de la Filología Latina, Madrid, S.E.L.A.T., 2002, II, pp. 1114-1126.

${ }^{66}$ Cf. B. Croce, España en la vida italiana, p. 72 y 167.

67 Poemata omnia, ed. 5, Amsterdam, 1670, en el prólogo a su hermano Guillermo Grocio (citado por J. Nowicki, Die Epigrammstheorie, p. 99 n. 269).

${ }^{68}$ Theod. Bezae poemata, ed. tertia, Ginebra, H. Stephanus, 1576, p. 146. 
Y el reverendo Thomas Bastard, tan enemigo de los españoles, entonó la mayor alabanza del epigramatista que hacerse pueda:

Martiall, in sooth none should presume to write, Since time hath brought thy Epigrams to lighte: For through our writing, thine so praised before Haue this obteinde, to be commended more: Yet to our selues, although we winne no fame, Wee plaise, which get our maister a good name ${ }^{69}$.

\section{Marcial en la España del s. XVI: libros y lectores}

La imprenta, a partir de 1471, puso en circulación las obras del epigramatista por toda Europa ${ }^{70}$. Otro tanto sucedió en España, aunque aquí no hubo ediciones del poeta: la escasez de lectores no compensaba el coste de la impresión. Por más que los datos más fiables de que dispongo son más tardíos y se refieren a una sola ciudad, Sevilla, las cifras hablan por sí mismas. En la almoneda de los bienes del librero Niculoso de Monardis, celebrada el 12 de setiembre de 1525, salieron a subasta 25 ejemplares de los Epigramas ${ }^{71}$. Entre los bienes del librero Cristóbal de Alfaro, presentado por sus hijos, Rodrigo de Ayala, beneficiado de Aznalcázar, y Alonso de Alfaro el 29 de noviembre de 153372, figura "i Marçial con comento". Choca, en cambio, la ausencia de los Epigramas en los libros dejados por el impresor Jacobo Cromberger a su muerte e inventariados el 7 de junio de 1529; pero en el correspondiente inventario de su hijo, Juan Cromberger, hecho el 20 de setiembre de 1540, se registraron "3 Marciales"73. Y que el interés por el bilbilitano fue después

${ }^{69}$ Chrestoleros. Seuen Books of Epigrames, Londres, 1598 (utilizo la edición de A. B. Grosart, 1880, p. 10), Epigr. I 17 ("de poeta Martiali").

70 Una útil reseña de las ediciones antiguas de Marcial hizo Frank-Rutger Hausmann, "Martialis, Marcus Valerius", en el Catalogus translationum et commentariorum. Medieval and Renaissance Latin. Translations and Commentaries, IV, Washington, 1980, pp. 249-96.

${ }^{71}$ Cf. J. Gil, El libro de Marco Polo anotado por Colón. El libro de Marco Polo traducido por Rodrigo de Santaella, Madrid, 1987, p. XXII.

72 A.P.S., I 1533, 3 (= 45).

${ }^{73}$ Cf. José Gestoso, Noticias inéditas de impresores sevillanos, Sevilla, 1924, p. 98 . 
en aumento lo demuestra el hecho de que en el fondo de libros de Francisco de Aguilar, fallecido en 1574 o 1575, se dispare ya la cifra hasta "diez Marciales"74.

A pesar de todo, no es el nuestro un autor que aparezca a menudo en los anaqueles de las bibliotecas sevillanas; en las eclesiásticas desde luego brilla por su ausencia (como falta en la de Isabel la Católica: no estaría bien visto que lo leyese una mujer y encima en un ejemplar de su propiedad; la misma restricción se aplica a los miembros del cabildo). Lo poseyó, claro está, Hernando Colón, y en tres ediciones, compradas las tres tempranamente ${ }^{75}$ : "Martialis opera, videlicet epigrammata et xenia et apophoreta cum commento Calderini et Georgii Merulae. 1999", la impresión de Venecia (1493)76; "Vita. Valerius Martialis. 2588" y "Selecta epigrammata libri primi per Buschium commentata. 889". Benito Arias Montano tuvo un ejemplar, "pequeño", según consta por su catálogo de $1548^{77}$, y dos, sin especificar, el doctor Constantino de la Fuente ${ }^{78}$. Así y todo, los Epigramas estuvieron ausentes de las bibliotecas de hombres cultos como D. Fadrique Enríquez de Ribera, primer marqués de Tarifa, el factor de la Casa de la Contratación Juan de Aranda, el doctor Francisco de Vargas, Pedro de Escobar, el veinticuatro Juan Gutiérrez Tello o Juan de Mal-lara. Este último, buen conocedor de Marcial, según veremos, tenía sólo unos Flores epigrammatum ${ }^{79}$; cabe sospechar que después de su dolorosa estancia en la cárcel de la Inquisición se deshizo muy a su pesar de una obra que podía ser considerada amoral y perniciosa.

${ }^{74}$ Cf. C. A. González Sánchez-N. Maillard Álvarez, Orbe tipográfico. El mercado del libro en la Sevilla de la segunda mitad del siglo XVI, Ediciones Trea, 2003, p. 168.

75 Cf. la edición facsímil Hernando Colón. Abecedarium B y Supplementum, Sevilla, 1992.

${ }^{76}$ Esra edición se conserva hoy (cf. A. Segura-P. Vallejo-J. F. Sáez, Catálogo de incunables de la Biblioteca capitular y colombina de Sevilla, Sevilla, 1999, n 808, p. 432), y a ella me referiré más adelante.

77 Es el no 91 (cf. J. Gil, Arias Montano en su entorno. Bienes y herederos, Badajoz, 1998, p. 172).

${ }^{78}$ Los no 854 y 858 en K. Wagner, El doctor Constantino Ponce de la Fuente. El hombre y su biblioteca, Sevilla, 1979, p. 101.

${ }^{79}$ Cf. F. Rodríguez Marín, Nuevos datos para las biografias de cien escritores de los siglos XVI y XVII, Madrid, 1923, p. 16. 
En Valencia la situación parece que fue la misma. En efecto, nada encuentro relativo a Marcial en el libro excelente de Ph. Berger, que da la lista de autores clásicos que se hallaban en las librerías de A. Busarán (†1508), Mateo de Mantagut, Galcerán Dalmau y J. Jofré (1542) $)^{80}$. Sólo en una gran biblioteca como la de D. Fernando de Aragón, duque de Calabria, aparece un "Martial, cubierto de cuero leonado"81; y conviene añadir que, además, el duque poseía la Antología Griega (no 338: Epigrammata Graeca, en $8^{\circ}$ ), los "Epigramas de Thomás Moro" ( $\left.\mathrm{n}^{\circ} 329\right)$ y unos "Epigrammata antiquae urbis" (no 432).

En Salamanca la situación es más halagüeña: los sensacionales descubrimientos de $\mathrm{V}$. Bécares ${ }^{82}$ permiten hablar con más propiedad y conocimiento de causa de la fortuna de Marcial en una ciudad universitaria. La compañía de libreros de Salamanca, cuyos riquísimos fondos podemos ahora apreciar en su justo valor gracias a los desvelos del gran investigador citado, recibió 538 balas de libros extranjeros de 1530 a 1533; en esas copiosas remesas se encontraban "31 Tex. Marcialis Alem. [¿Argentinae, 1515? ¿Antuerpiae, 1530?]" (no 1143 [p. 92]), "4 Tex. Martialis Colinei [en realidad, una copia de la Aldina de 1501, Parisiis, apud Simonem Colinaeum, 1528]" ( $n^{0} 1181$ [p. 93]), "10 Tex. Martialis Alem." (no 1213 [p. 94]); también entre los libros que estaban en camino se hallaba "1 Martialis Aldi [¿1517?] ¿dore Rel.?" (no 441 [p. 161]). De ese total de 45 ejemplares quedaban en 1534 sin vender los siguientes: dormitaban en el almacén de Pedro de Santo Domingo en Medina del Campo "1 Marçial con comento Lion" (no 1049 [p. 258]) y en la tienda de Cristóbal de Pascua en Salamanca "1 textus Marçial Alemaña" (p. 281) y "1 Martial con comento" (p. 315). Por tanto, parece que la compañía de libreros había vendido en total 42 ejemplares de Marcial en cuatro años. La cifra parece alta -la Universidad suministraba un plantel de clientes, y aun la compañía distribuía sus fondos a otras partes: Jacobo Cromberger le compró en 1530 "1 Martialis cum comento" ( $\mathrm{n}^{\mathrm{o}} 154$ [p. 177])-, pero no llega ni con mucho a la profusión de ejemplares vendidos de otros autores como Juvenal.

${ }^{80}$ Libro y lectura en la Valencia del Renacimiento, Valencia, 1987, I, p. 286 n. 152; I, p. 287 y II, p. 507; cf. asimismo I, p. 381.

${ }^{81}$ Inventario de los libros de Don Fernando de Aragón, duque de Calabria, Madrid, $1875, n^{\circ} 353$, p. 37. Debo esta cita a mi hermano L. Gil.

${ }^{82}$ La compañía de libreros de Salamanca (1530-1534, Salamanca, 2003. 
En 1592 Benito Boyer, librero de Medina, contaba entre sus fondos "nueve Marcial epigramata, in diez y seis, a quatro sueldos: son una libra y diez y seis sueldos" y "siete Marcial epigramata, octavo, a cinco sueldos y seis dineros: son una libra y diez y ocho sueldos y seis dineros" ${ }^{\prime \prime 2}$, quizá, como apunta Bécares, alguna de las ediciones de Ant. Gryphius.

Muchos humanistas, de una manera o de otra, tuvieron conocimiento del poeta de Bílbilis, mas sólo en un caso nos es dado sorprenderlos en el momento mismo en que lo leyeron. Este caso único es el de Hernando Colón, que hizo un estudio atento y pormenorizado de Marcial cuando todavía era muy joven, enfrentándose a las dificultades del texto gracias a los comentarios de Calderini y Mérula impresos por Bartholameus de Zanis de Portesio, volumen que adquirió en Roma por 112 cuatrines en 1512. Apenas hay en este libro epigrama que no reciba una anotación con su letra diminuta, esa letra de pulga que ya habíamos descubierto garabateando en los márgenes del libro de Marco Polo o de Estrabón ${ }^{84}$. Con gran paciencia el gran bibliófilo fue señalando sobre el renglón las correspondencias léxicas, que dio de vez en cuando en castellano, sobre todo en los Xenia: "betae: acelgas" (XIII 13 [f. 140r]), "rapa: nabos" (XIII 16 [f. 140r]), "caules: berças" (XIII 17 [f. 140r]), "sorba: serua Hispanice (XIII 26 [f. 140v]), "cariota: datil" (XIII 27 [f. 140v]), "caeli: pinzel" (XIV 93 [f. 152r]). Sintiéndose ya más seguro en sus latines, D. Hernando se atrevió incluso a proponer interpretaciones de su cosecha, a decir verdad no muy acertadas. Para razonar la primera (IV 85) le sirvió de base su experiencia romana: "Aut possumus alio modo intelligere, quod aqua prius in uase aliis asportabatur et vinum pincerna desuper infundebat, ut moris de presenti est inter Romanos. Verum Ponticus illectus vini cupiditate vinum sibi in vase asportari jubebat, et ut conuiuis aqua $\{\mathrm{m}\}$ uideretur, alium [= aliud] a pincerna desuper infundere faciebat; et ne hoc detegeretur mirrino uase utebatur" (f. 49r). Otra sugerencia, tampoco muy feliz, hizo a X 95: "Infantem etc. Potius intellego quod uterque infantem remittebat quia con $<$ s $>$ cius erat adulterij Galle, ex quo cuique eorum cuius esset infans incompertum erat" (f. 116r). En otro lugar (XIII 11) anotó una interpretación de Antonio de Lebrija: "Nebrisa

${ }^{83}$ V. Bécares, La librería de Benito Boyer. Medina del Campo, 1592, Junta de Castilla y León, 1992, p. 113 (nº 429 y 430)..

${ }^{84}$ Biblioteca de Colón. El Libro de Marco Polo. Las apostillas a la Historia Natural de Pinio, Madrid, 1992, p. XLss. 
ita exponit: Accipe, scilicet ordeum, quod mulio, scilicet tuus, non det, id est, non dabit, mulis tacituris, scilicet, quia cum sint mute, non querentur sibi non oblatum ordeum a mulione fure fuisse, qui mulio clam cauponi in vini pretio dedit; et ideo rectius possem dicere: Hec ego coponi, non tibi dona dedi" (f. 139v). En f. 107v advirtió que hay una "mutatio" en la sensibilidad de Marcial, al destacar la diferente apreciación que hace el poeta de la "hazaña" de Escévola en VIII 30 y en X 25. Al llegar a XIII 4 (Tus) apuntó con razón: “Ex hoc distico patet xenia non post $12 \mathrm{~m}$ libros edidisse M." (f. 139v).

\section{Imitaciones latinas}

Como señaló James Hutton ${ }^{85}$, si en la Italia del s. XV el epigrama tuvo más sabor a Marcial, en el s. XVI predominó como modelo la Antología griega (la Planudea, evidentemente): hasta la primera mitad en la poesía latina, durante la segunda mitad en la poesía vernácula a través de las imitaciones latinas: p.e., de los 114 epigramas de Luigi Alamanni 35 son imitaciones del griego. Es lógico, por ende, que en la Península Ibérica, $\tan$ dependiente de Italia ${ }^{86}$, nuestros primeros humanistas se amoldaran de preferencia a la norma helénica ${ }^{87}$ : tanto los epigramas latinos de Lebrija ${ }^{88}$, el Pinciano o Garcilaso como los de Arias Barbosa o Enrique Caiado carecen por lo general de punta, ese aculeus que pronto se considerará imprescindible para alcanzar la excelencia; prima, en cambio, la suauitas y el lepor, no siempre conseguidos. En Alcalá de Henares el helenista Juan de Vergara, el admirador de Erasmo, no sólo fue un entusiasta propagandista de la Antología Griega, sino que él mismo compuso epigramas a la manera helénica, como aquél en que se queja de que su enamorada, que le manda un coral (corallium) para aliviar su acidez de

85 The Greek Anthology in Italy to the Year 1800, Cornell Studies in English XXIII, Ithaca-Nueva York, 1935, p. 49.

${ }^{86}$ Un ejemplo entre mil: Caiado expresó su deseo de que el bastardo real, D. Jorge, pudiera tener una oratio tota transmarina, es decir, que su latín se pareciera por completo al de los italianos (Cl. Balavoine, Les Éclogues d'Henrique Caiado ou l'Humanisme portugais à la conquête de la poèsie néolatine, Lisboa-París, 1983, p. 94).

${ }^{87}$ J. Nowicki, Die Epigrammstheorie, p. 54ss.

88 Es llamativo que el Nebrisense citase un epigrama de la Antología Palatina (X 39) en el prólogo de su Gramática (cf. J. Nowicki, Die Epigrammstheorie, p. 73). 
estómago, no se lo dé por entero, sino que se haya quedado en realidad con las primeras letras del nombre, es decir, con el corazón (cor) del poeta (p. 497 bis A. Álvar) ${ }^{89}$ :

Planta olim, nunc gemma rubens, non te mihi totam

Dat domina: heu! retinet prima elementa sibi.

Su discípulo Álvar Gómez de Castro (1515/16-1580) tradujo al latín varios poemas de Meleagro (en un caso, de Estratón, en dos versiones: XXV-XXVI = A.P. XII 235), Nicarco (CCXLVIII = A.P. XI114), Páladas $(X X X I=A . P . X 73)$, Luciano (en cinco versiones: XXVII, CLXXII-CLXXIII, CCLXVIII-CCLXIX = A.P. X 31) y otros de autoría desconocida (así, también en dos versiones, CLXXIV-CLXXV = A.P. XI 51 o los epitafios de Diógenes: CXLV-CXLVI, CXLIX = A.P. VII 64-65, 67); en el Parnaso helénico -antes que en la Musa cristiana- aprendió Castro a adaptar al metro dactílico raros vocablos como nycticorax (LXII $13=$ A.P. XI 186) y a usar expresiones como lac Veneris cerebrumque Iouis (LVI 3) $=\Delta$ iòs

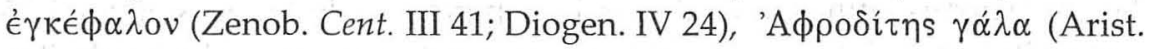
Ran. 596). Y es más: el discípulo consiguió que su maestro rivalizara con él en la versión de diversos poemas, como el de Estratón; era dulce aprender compitiendo con una persona tan docta como Juan de Vergara y haciendo bueno el proverbio $\delta$ is $\delta \imath \grave{\alpha} \pi \alpha \sigma \hat{\omega} v^{90}$; la misma amistosa emulación habían practicado Tomás Moro y Guillermo Lily en sus Progymnasmata, por poner el ejemplo de un autor leído por Castro. El influjo indirecto de la Antología griega se deja sentir hasta en la inscripción funeraria que el famoso médico Andrés Laguna puso a su padre Diego Fernández de Laguna en 1557, reproduciendo un dístico famoso ya en la Antigüedad latina e imitado después por Petrarca, Juan Panonio, Moro, G. Lily y Le Sage ${ }^{91}$ :

Iam portum inueni. Spes et Fortuna, ualete.

Nil mihi uobiscum. Ludite nunc alios ${ }^{92}$.

${ }^{89}$ Cf. epigramas como los enigmas del libro XIV de la A.P.: 22, 35, 105, 106, etc.

${ }^{90}$ Hay que leer paremian y no paremptam (p. 497 Alvar), cf. Plut. Mor. 1019b.

${ }^{1}$ Cf. Hutton, The Greek Anthology in Italy, p. 27; The Greek Anthology in France, pp. 514-55; H. H. Hudson, The Epigram in the English Renaissance, Princeton, 1947, pp.38-39.

${ }^{2}$ Cf. D. de Colmenares, Historia de la insigne ciudad de Segovia, Segovia, 1991, III, p. 55. Una versión muy parecida del dístico se encuentra en CLE 1498; 2139, 
De ahí proviene cierta ambigüedad terminológica, una perceptible laxitud conceptual: Pedro Núñez Delgado puso a sus poesías el nombre de Epigrammata (Sevilla, 1537) pero igual las podría haber llamado Siluae: desde luego, epigramas al estilo de Marcial no lo son en modo alguno ${ }^{93}$.

Un nuevo estímulo para escribir poesías en latín provino de las justas poéticas. Como es sabido, en Sevilla instituyó un certamen anual de este tipo D. Baltasar del Río, obispo de Scala, cuando fundó la cofradía de Nuestra Señora de la Consolación en $1531^{94}$. El tema a tratar por los concursantes, propuesto previamente por el cabildo catedral, era siempre de índole religiosa (alabanza de algún santo, en latín y en castellano, en prosa y en verso), pero al menos propiciaba el ejercicio de la composición latina en el difícil campo de la métrica clásica.

Un códice facticio de la Biblioteca Capitular de Sevilla95 conserva los originales de las poesías presentadas al certamen del obispo de Scala, por lo que nos es conocida hasta cierto punto la mecánica interna de los premios. Dos frailes certificaban la ortodoxia de los conceptos vertidos en la poesía, y otros dos expertos, también eclesiásticos, juzgaban la pureza de su gramática y prosodia. Los censores teólogos fueron muy variados ${ }^{96}$. En cambio, el segundo tribunal, por su misión más comprometida y específica, cambió menos de composición: fueron miembros casi permanentes

cf. Plin. Ep. IV 11, 2, CLE 409, 8; 434, 13, Anth. Lat. 667, Eugen. Tol. Carm. App. 51, 4 (MGH, Auct. Ant. XIV, p. 282); es traducción de A. P. IX 49, cf. IX 134 y 172. Lo imitó el Brocense en un dístico (XLVII [p. 122 A. Carrera de la Red]).

${ }^{93} \mathrm{~J}$. Nowicki señala con razón, sin embargo, que hasta Catulo por lo menos no hubo una concepción cerrada del epigrama, que fue confundido a veces con la elegía (Die Epigrammstheorie, p. 12ss.)

${ }^{94}$ Cf. sobre su figura J. Gil, Los conversos y la Inquisición sevillana, Sevilla, 2000, II, p. 50ss.

${ }_{95}$ Ms. 64-7-90 (actualmente 59-6-14).

${ }^{96}$ Lo fueron, p.e., Los frailes Pedro Arias, Jerónimo Bravo (de Laguna), Juan de Burgo, Martín Cano, Pedro de Casagrande, Alfonso de Casaus, Diego de Castro, Alfonso Chacón, Andrés Daza, Alonso de la Fuente, Antonio de las Infantas, Juan Martínez, Álvaro Melgarejo, Gaspar de Mendieta, Antonio de Morales, Miguel de Ocaña, Juan Ochoa, Alonso de Ortega, Diego de Perales, Diego de Poblete, Alonso de Rojas, Andrés Romero, Juan de San Miguel, Felipe de Sosa, Remigio Tamariz, Gaspar Tremiño, Domingo de Valtanás, Francisco Venegas, Miguel de Zuloaga, etc. 
del mismo el doctor Alonso de Medina y Juan de Quirós, clérigo del Sagrario (el maestro de Arias Montano), aunque algunas veces Quirós fuera sustituido por Luis de Ávalos ${ }^{97}$. Nada sabemos del año en que se celebraron estas justas, salvo que una de ellas, la dedicada a Santo Domingo, tuvo lugar en setiembre de 1549 (f. 118r). Normalmente el metro empleado era el dístico elegíaco, si bien algunas poesías están en hexámetros. Se concedían tres premios, cada uno dotado con su galardón respectivo que, en su escala más baja, consistía en un par de guantes ${ }^{98}$.

Por parecerme inéditos, reproduzco a continuación dos epigramas de este precioso códice ${ }^{99}$. El primero es de Fernando de Herrera, con toda probabilidad el gran poeta (f. 149r), del que con justicia anotaron los jueces: "Hec carmina digna sunt praemio, si certant".

Hernando de Herrera. In laudem sancti Hermenegildi.

Regia progenies benit Emergildus. Adeste, Pierides: festus ducitur iste dies.

Martiris Hispani meritas vos dicite laudes

Et certet culto carmine docta cohors.

5

Vltimus effuso meruit qui sanguine celum

Dum damnat Pharii dogmata praua senis,

${ }^{97}$ Los jueces llevaron a cabo concienzudamente su labor. Así lo demuestran las siguientes anotaciones al margen de los distintos epigramas: "Religio primam corripit nisi per duplex .11. scribatur, ut relligione patrum multoties" (f. 13r); "Huic uersui (Silicet est hostes uincere, parcere uictis) deest una syllaba. Hoc epigramma non certat propter mendas aut syllabae defectum" (f. 18r); "Repperis tiene dos vicios, porque tiene dos $p p$, lo qual no se permite sino en el pretérito; demás d'esto el -is final es luengo y aquí lo pone breve" (f. 30r); "Pontificisque senex pileos excussit oblatos: / hoc duce coenobius fit nouus ordo fratrum" i. longum, a. longum (f. 167); "quod iam certe poli viuis in arce quidem" e longum (f. 176 bis); "Anna precor nobis placido tu prospice uultu / Qui refero indignus candida facta tua". Prospice nobis placido uultu uidetur soloecismus. Item qui refero (f. 210r).

98 "Llevó la joya primera" (f. 160r), o bien "llevó sus guantes" (cf. f. 108r, 110r, 112r, 113r, 115r, 116r), "llevó un par" (f. 155r), "llevó dos pares" (f. 158r).

${ }^{99}$ Editó un poema de Pedro Fernández sobre este códice J. Pascual Barea, "El músico y poeta Pedro Fernández de Castilleja, maestro de capilla y de Gramática griega y latina en Sevilla (c. 1487-1574)", Calamus renascens, II (2001) 338 ss. 
Rex erat a teneris Tyrio spectabilis ostro,

Sed regni pessum culmina celsa dedit

Iussaque contempsit praui genitoris et heres

10

Offensa Christi noluit esse fide.

Sacrilegos tenera gladios ceruice recepit

Ac per calcatum tendit ad astra patrem.

12 patrem s.v. correcto ex celum

El segundo es de Francisco Morcillo de Fox, sin duda un hermano de Sebastián Fox Morcillo, y contiene un error de prosodia, como indicaron muy oportunamente los jueces.

Francisco Morzillo de Fox. In laudem sanctissime crucis epigramma.

Crux pia, quae miseris effecta es meta laboris,

Cuius et ara deo, victima diua, placet,

Ergo iure tibi redduntur carmine laudes

Cum per te redeat gratia, vita, salus.

5 In media impulerat fractos nos aequora daemon,

Sed facta es lapsis tabula naufragii.

Virgo dedit prolem, quam pulchra stirpe tulisti,

Vitae igitur nobis tu quoque reddis opem:

Nam tua poma viro si imprudens Eua dedisset,

10 Traderet haud nostras in sua vincla manus.

Plura quid hic referam? Qui caelum et sydera calcat

Ipse sacris humeris te super imposuit.

6 tribrachus, non recipit versus exameter adnotauit iudex.

Como puede fácilmente comprobarse, hay poco de Marcial en estas poesías. El modelo seguido es a todas luces Virgilio, muchas veces remedado sin tapujos. Así, un epigrama de Diego López a San Alejo, que se llevó el tercer premio, es - ¿quién lo iba a decir?- una contrahechura de la Bucólica II por el fácil asidero del nombre Alexis (f. 59r). De la misma manera, otro epigrama de Venegas a San Ambrosio imita los primeros versos de la Eneida (f. 188r). Aun así, no faltan algunas reminiscencias de Marcial. Un epigrama de Pedro Gómez a San Cristóbal comienza de la siguiente manera (f. 31r):

Eximii quondam celebratus roboris Atlas Iam poterit magno cedere Christophoro.

Saepe etenim ridetur Atlas, quod pondera gibbo

Vix ferat et speciem pene ruentis agat. 
Un juez anotó muy puesto en su papel: "agere speciem no me parece bien dicho. Tanpoco me parece bien redetur Atlas, en que quiso imitar un verso de Marcial fuera de propósito". La alusión parece ser a I 14, 8 inter Ledaeos ridetur coruus olores y sobre todo a VI 67, 7 non aliter monstratur Atlans cum corpore gibo (así las ediciones que pudieron leer los poetas sevillanos, y más concretamente el Martialis cum duobus commentis de la Colombina: hoy se acepta la corrección de Schrijver ginno).

Volvamos ahora los ojos a Salamanca, donde la Universidad daba alas a las competiciones poéticas y donde, por tanto, mejor podía florecer el epigrama. Es lástima grande que la producción latina de aquella Salamanca ilustre esté hoy perdida en su mayor parte o bien oculta en lugar desconocido. En realidad, sólo puedo decir que se haya reencarnado algo del espíritu de Marcial en un autor: el profesor de Retórica Miguel Villegas. Villegas es hoy poco más que una sombra, un humanista desconocido incluso para Nicolás Antonio. Gracias a un discípulo suyo, Tomás Pinhel, de quien hablaremos a continuación, podemos hacernos una idea de su ingenio, del que doy como muestra tres epigramas ${ }^{100}$. Los dos primeros ridiculizan una cabeza inmensa, de la que el cuerpo es sólo un apéndice. Es un viejo y manido tema que remonta a la Antología Palatina (XI 109); la misma gracia fue aplicada a una nariz descomunal por Teodoro (A.P. XI 198), Leónidas (A.P. XI 199200, cf. los epigramas anónimos 203-204), Nicarco (A.P. XI 406) y Marcial (XIII 2 1-2), origen último del famoso soneto de Quevedo ${ }^{101}$, y a otro miembro más obsceno por Catulo $(116)$ y Petronio $(92,9)^{102}$. El tercero se

${ }^{100}$ La poesía sagrada de Venegas se encuentra en el ms. RAH E-65 (ahora 9/5880), ff. 123r-136v; la profana, dedicada a D. Bernardino de Mendoza, la que más nos interesa, en ff. 137r-151r. El códice, una copia tardía y plagada de errores del ms. D-206, muy deteriorado, lleva el título de Varias poesías sagradas y profanas y algunas de autores conocidos. Lo describió sumariamente con las poesías del Brocense en él contenidas A. Carrera de la Red, Francisco Sánchez de las Brozas. Obras. II. Poesía, Cáceres, 1985, p. 26ss.

101 Cf. Ma R. Lida de Malkiel, "Notas para las fuentes de Quevedo", Rev. Filol. Hisp. I (1939) 369ss.

102 Habebat inguinum pondus tam grande, ut ipsum hominem laciniam fascini crederes. Comenta L Ramírez de Prado (Hypomnemata, p. 55): "Erat tantus Priapus, ut homo ipse appendix eius uel lacinia esse uideretur". La misma broma, a mi juicio, gastó Augusto a Horacio cuando lo tachó de purissimus penis, según sabemos por los restos de la vida suetoniana. Otras comparaciones, chistosas por lo exagerado, 
refiere a las nuevas y holgadísimas calzas que se habían puesto de moda entre los niños.

Ad quendam cui pileus erat latissimus, altior tamen capite

Pileus iste tuus frontem tibi non tegit omnem:

Corporis existat longa lacerna mei;

Quattuor aut plures possent habitare sub illo,

Si domus aetherio nulla sub axe foret;

5 Hunc Ajax clypei septemplicis instar haberet,

Aegidis hunc cuperet Pallas habere loco;

Eius in orbe triceps latitare Chimera valeret,

Tergeminique velint *** Geriones.

Mole sub hac numerus tegeret<ur> maior Achivûm

10 Quam texit Phrigiae proditor arcis equus.

Phoebeos radios vitaret mille carinis,

Commoda et umbra potest urbibus esse decem.

Mille sub hoc fortis tentoria fingeret Hector,

Aequalem Byrsam optet Elisa suam.

15 Pauca in frustra seca: centum circumdabis urbes.

Intactum serva: pileus orbis erit.

Lemma: angustior pro altior expectaueris 8 Tergeminique scripsi (collatis Lucr. 5 , 28; Verg. Aen. VIII 202) : tres geminique ms. // lacuna in ms. 9 addidi $\mathbf{1 5}$ urbes scripsi : orbes $m s$.

\section{f. 134r Alterum}

Cum caput intueor corpus reor esse gigantis;

Cum video corpus, tunc caput esse puto.

De nostri temporis femoralibus

Bis genitum, vates antiqui, credite Bacchum

Et patrium caesa matre subisse femur;

Amplius humana fieri nunc arte uidemus,

Divina fecit quam deus almus ope;

5 Ecce tibi utriculum, panem, cultrum atque libellum

Temporibus nostris fer $<t>$ puerile femur.

Hoc ferre est Bacchum, Cererem, Martem atque Mineruam.

Prisca suum iactant quid mihi saecla Jovem? ${ }^{103}$

6 addidi

relativas a una pequeñez o grandor desmesurados en $A P$ XI 87ss. También Domingo Andrés se burló de un médico de corta estatura (LXXXI, p. 118 Maestre).

${ }^{103}$ Ms. RAH E-65 (ahora 9/5880), ff. 133v-134r. 
Villegas probó a hacer invectivas satíricas. Nada menos que nueve epigramas compuso el humanista contra Calvino, siguiendo el triste patrón de intolerancia que imperó en los s. XVI y XVII. Baste con reproducir aquí dos de ellos. El primero es una imitación clara de Marcial (II 38), aunque incurre por salvar el metro en una falta de sintaxis (tulit por tulerit); en el segundo se busca, haciendo un juego de palabras con calere y uinum, una chusca etimología del nombre propio ${ }^{104}$ :

$5 \mathrm{~m}$. Mortuus ad Calvinum

Quanta mihi, Calvine, tulit mors commoda quaeris?

Commoda magna tulit: te modo non video ${ }^{105}$.

$7 \mathrm{~m}$.

Calvinus, vino quia bruma et vere calescis,

Dictus es: Alpinas ne vereare nives ${ }^{106}$.

2 niues scripsi : vives $m s$.

Entre los más prolíficos epigramatistas del s. XVI se encuentra un discípulo de Villegas, Tomás Pinhel, hijo de un portugués ilustre, Arias Pinhel. Bien se merecen uno y otro que les prestemos alguna atención. La vida del padre, un jurista de fama que escribió varios tratados importantes ${ }^{107}$, transcurrió entre España y Portugal. En 1529, sin haber cumplido todavía los quince años, estudió Leyes en Salamanca con Antonio Gómez y Martín de Azpilcueta. La fama conseguida le valió que la recién creada

${ }^{104}$ Más duro fue el anagrama que hizo el jesuita Bauhuis contra Calvino en dímetros yámbicos (Bernardi Bauhusii et Balduini Cabillaui e Soc. Iesu epigrammata, Caroli Malapertii ex eadem Soc. poemata, Antuerpiae, ex officina Plantiniana Balthasaris Moreti, 1634, p. 52):

$$
\begin{aligned}
& \text { Caluinus at (Satanico } \\
& \text { O digna mors Apostolo) } \\
& \text { Voratur a foedissimis } \\
& \text { Pedi- (quid impedis pudor? } \\
& \text { Sine, uindicem Deum loquar) } \\
& \text { Voratur a pediculis. }
\end{aligned}
$$

${ }^{105}$ F. 145v.

106 F. 146r. El mismo chiste fácil hizo Lope de Verga en su Brasil restituido: "Vinistas no sólo son / por el vino, que añadiendo / tres letras, son calvinistas".

107 Le dedicó una entrada Nicolás Antonio en su Bibliotheca Hispana nova, Madrid, 1783, I, pp. 169-70, cf. p. 345; son más más completas las noticias de D. Barbosa Machado, Bibliotheca Lusitana, Coimbra, 1965, I, p. 79. 
Universidad de Coimbra le diera en 1539 la cátedra de Digestos, con salario de 60.000 mrs., cátedra que leyó durante 11 años. Insatisfecho con la docencia, dejó la Universidad conimbricense y abrió bufete como abogado en la Corte lusa, aunque al cabo de 6 años el rey lo envió de nuevo a Coimbra para leer cátedra de Vísperas ${ }^{108}$. En 1561, sin embargo, opositó con su colega conimbricense Manuel de Acosta a la cátedra de Prima de Salamanca ${ }^{109}$, que ganó Acosta, aunque la Universidad, para no desairar a Pinhel, le concedió una cátedra extraordinaria con un sueldo de 300 ducados $^{110}$. Finalmente fue nombrado oidor de Lisboa.

Su hijo Tomás, que abrazó el hábito de San Francisco, siguió la senda paterna y también estudió en Salamanca, pero en el Colegio Trilingüe, donde lo encontramos llevando la beca de colegial en 1573 y 1574. La Universidad contaba entonces con un buen plantel de profesores; de ellos recordó Pinhel en sus poesías a Francisco Sánchez de las Brozas (f. 196r) ${ }^{111}$, a Castro, el comentarista de Aristóteles (f. 95v), al lector Navarro y a Miguel Venegas (f. 122r), profesores de Retórica (f. 96v), y a Juan Escribano, profesor de griego (f. 197r). Durante su infancia o en estos años alegres de aprendizaje conoció y trabó amistad con buen número de portugueses, a los que después celebró en sus versos: D. Juan Teles (f. 213v), el famoso jesuita madeirense Manuel Alvares (f. 216r) ${ }^{112}$, Ignacio de Morais (el Morales de f. 219v, 223r) ${ }^{113}$, Diego Barbosa (f. 109r) o Manuel Correa (f. 219r). En 1576, acabados sus estudios, se trasladó a

${ }^{108}$ Ms. RAH E-65 (ahora 9/5880), f. 298v ss.

109 "Año de 1561 en la vacante de la cátedra de prima, que fue opositor mi señor padre el doctor Ayres Pinel" (ms. RAH E-65 [ahora 9/5880], f. 282v).

${ }^{110}$ En 1568 se publicaron en Salamanca sus libros Ad constitutiones, codice de bonis maternis, commentarii y Ad rubricam et legem secundam codice de rescindenda venditione commentarii (cf. L. Ruiz Fidalgo, La imprenta en Salamanca (1501-1600), II, Madrid, 1994, no 681 (p. 628), 681 A (p. 629).

111 El Brocense lo recordó en una poesía a León de Castro: "Insignem pietate uirum ne omitte Pinellum / Sacrum oratorem, relligione grauem" (XXXIII 13-14 [p. 110 A. Carrera de la Red]).

112 Probablemente manejó sólo sus obras (cf. sobre él N. Antonio, Bibliotheca Hispana nova, I, p. 341).

${ }^{113}$ A este personaje, que era jurista como su padre, quizá lo conociera en Coimbra (cf. sobre él N. Antonio, Bibliotheca Hispana nova, I, pp. 624-25; J. F. Alcina, Repertorio de la poesía latina del Reancimiento en España, Salamanca, 1995, no 291, f. 143). 
Cuenca, a la sombra del mecenazgo que le brindó el arcediano D. Luis de Castilla $^{114}$.

Tomás Pinhel sintió la vocación de poeta desde su juventud, y esta faceta de su personalidad prima sobre todas las demás. Cualquier acontecimiento era bueno para dar rienda suelta a su inspiración. Cuando entró en la Orden seráfica, el novicio compuso una elegía en honor de su santo patrono ${ }^{115}$. Después, siendo ya colegial del Trilingüe, concurrió asiduamente a los certámenes de poesía que convocaba la Universidad, en cuyo tribunal figuraban maestros y poetas tan eximios como fray Luis de León. Conocemos dos de los galardones que recibió Pinhel como poeta latino: en mayo de 1574 ganó el libro De iustitia del portugués Jerónimo Osorio, y en junio del mismo año fue premiado con tres varas de tafetán amarillo ${ }^{116}$. En ese mismo año de 1574 Pinhel empezó a reunir las poesías suyas y de sus amigos y maestros en un códice manuscrito bajo el epígrafe IHS XPS Musis dicatum opus Collegerat F.T.P.M. (f. 12), que se abre con un Epigramma in meorum carminum maledicum:

Paulatim crescit discendo scientia fitque Major et ingenium non rude Phoebus amat.

In mentem revoces nihil omni ex parte beatum.

Quod modo si feceris, praemia magna feres.

Non ideo temnas nostri rudimenta laboris:

Ex parvis fieri maxima saepe solent ${ }^{117}$.

La Musa del poeta bisoño que era Pinhel resulta fácil, suelta, llena de ternura: en definitiva, muy franciscana. Los temas tratados son los de

114 Así lo prueban varias poesías escritas en Cuenca: el encomio del Santísimo Sacramento (Ms. RAH E-65 (ahora 9/5880), f. 23r) o las alabanzas al arcediano D. Luis de Castilla (ibidem, f. 73r, 75r, 80r, 327r).

115 "Elegia quam ego F. Tomas Pinelus feci tempore quo ingressus fui religionem Seraphici P.N. F. pauperum patriarchae in eiusmet laudem" (Ms. RAH E-65 [ahora 9/5880], f. 17r).

116 "Hec carmina feci Salmanticae existens collega Trilinguis et illorum praemium mihi tributum fuit Osorii Lusitani celebre opus de Iustitia anno 1574 mense Maji in antiquo et religioso conuentu S.P.N.F.Salmanticensi". "In illud a Sansonis patre oblatum sacrificium Iud. 12. F. Thomas Pinelus, qui Salmanticae secundum praemium, s. gilvi tafetani ulnas tres obtinuit in scholis Majoribus anno 1574 mense Junii" (Ms. RAH E-65 [ahora 9/5880], f. 111r).

${ }_{117}$ Ms. RAH E-65 (ahora 9/5880), f. 13r. 
siempre: alabanzas de la Virgen, del Niño, de los santos de la Orden (San Buenaventura, San Antonio de Lisboa, Santa Clara), exaltación de misterios como la Resurrección, etc. Presento dos epigramas que dan idea cabal de su vena poética. El primero de ellos es una contrahechura a lo divino de un poema muy humano de Marcial (V 55: el diálogo con el águila que lleva a Júpiter enamorado de Ganimedes; ya Alciato, en su Emblema IV, había dado una interpretación cristiana al mito de Ganimedes, siguiendo la tradición platónica):

Ad Virginem Deiparam dialogismus.

Quem manibus gestas, pulcherrima Virgo? Tonantem.

Cur venit in terras +raulus+ inermis? Amat.

Quo calet igne puer? Generis succensus amore

Humani: humanus nascitur ecce Deus ${ }^{118}$.

3 an paruus? 4 succensus scripsi : succenso $m s$.

Ad Jesum Salvatorem natum

Ne plora, formose puer, spes unica matris:

Quo tua membra tegat uix tua Mater habet.

Vbera plena tibi fecundo lacte reservo.

Virgineus peperit has mihi partus opes.

$5 \quad$ Has cape; plura darem, si tu mihi plura dedisses.

Lac bibere omne potes. Desine flere, puer ${ }^{119}$.

3 fecundo scripsi : facundo ms. 4 opes scripsi : spes ms.

El Cancionero se fue engrosando con el paso del tiempo hasta convertirse en el volumen misceláneo que ahora conocemos, un códice que contiene poesías de Pinhel y de otros poetas para celebrar acontecimientos coetáneos, como la victoria de Lepanto (1574), la muerte de D. Sebastián en Alcazarquivir (1579), la elección como Pontífice del franciscano Peretti (Sixto V) en 1585, la beatificación de San Diego de Alcalá (1589) o la muerte de Felipe II (1598). Además, Pinhel incluyó obras en prosa de sus maestros, como el comentario del Brocense a las Bucólicas. Una serie de epigramas revela ya la eclosión del manierismo que precede al barroco, contrahaciendo de nuevo poesías paganas a lo divino. He aquí, p.e., un enigma en dos variantes (una de ellas de fray Tomás), que juega

${ }_{118}$ Ms. RAH E-65 (ahora 9/5880), f. 14v

${ }_{119}$ Ms. RAH E-65 (ahora 9/5880), f. 15r. 
con la famosa contraposición entre Adán y Cristo y evoca al tiempo un no menos célebre verso de Ennio (Ann. 370 Vahlen: Vnus homo nobis cunctando restituit rem):

Aenygma

Vnus homo nobis pereundo perdiderat rem.

Vnus homo nobis pereundo restituit rem.

Vel sic F.T ( $=$ frater Thomas).

Vnus homo nobis uescendo perdiderat (escrito perdidit) rem.

Vnus homo nobis moriendo restituit rem ${ }^{120}$.

Es lástima que no sea segura en todos los casos la atribución de los epigramas a Pinhel. Así ocurre con una especie de trabalenguas referido a Cristo, triunfador de la muerte, con una aliteración asimismo muy enniana (Ann. 109 Vahlen: O Tite tute Tati tibi tanta tyranne tulisti):

Mors mortis, morti mortem mors morte dedisti ${ }^{121}$.

Un dístico juega con los nombres de Violante, las violetas y la violencia:

Misisti uiolas, ut me uiolentius uras.

Heu uiolor uiolis, heu Violante, tuis! ${ }^{122}$.

Estos manierismos son más propios de la poesía tardoantigua que de los poetas del s. I. Sin embargo, uno de estos epigramas de atribución incierta, dedicado a Miguel Ángel, reza así:

Hic situs est Michael, timuit quo sospite uinci

Natura omnipotens, et moriente mori ${ }^{123}$.

Es una poesía impecable, que parece desarrollar una secuencia muy típica de Marcial: II 91, 1-2 Caesar, sospite quo magnos credimus esse deos; cf. Esteban Rodrigues de Castro, ep. XCVI 1, Gaudenti, nostra haec quo sospite saecula gaudent ${ }^{124}$ (más lejano es el paralelo de Verg. Aen. XI 56-57). No

${ }^{120}$ Ms. RAH E-65 (ahora 9/5880), f. 23v =127r.

${ }^{121}$ Ms. RAH E-65 (ahora 9/5880), f. 54r.

${ }^{122}$ Ms. RAH E-65 (ahora 9/5880), f. 206r.

${ }^{123}$ Ms. RAH E-65 (ahora 9/5880), f. 205v. En el Repertorio de Alcina (p. 167) se lee por errata sapite en vez de sospite.

${ }^{124}$ Edición de G. Manupella, Coimbra, 1967, p. 438. 
hay tal, sin embargo: se trata de una copia casi literal de otro dístico de Bembo, éste dedicado a Rafael Sanzio ${ }^{125}$ :

Ille hic est Raphael, metuit quo sospite uinci

Rerum magna parens, et moriente mori.

La misma idea de que la naturaleza muere con el genio se expresa en el cenotafio a Shakespeare puesto en la iglesia parroquial de Stratfordon-Avon:

Stay, pasenger, why goest thou by so fast?

Read if thou canst, whom envious death hath plast

Within this monument: Shakspeare, with whom

Quick nature dide, whose name doth deck this tombe

Far more then cost. Sith all, that he hath writt,

Leaves living art, but page, to serve his witt ${ }^{126}$.

Por otra parte, el primer hemistiquio suena al comienzo del epicedio compuesto por Jerónimo a Miguel Verino, publicado en Salamanca con los famosos Disticha en 1559 y que sin duda leyó nuestro fraile: Hic situs est Michael sexta trieteride raptus ${ }^{127}$. Como se ve, incluso en esta producción latina de la segunda mitad del s. XVI puede suceder que los epigramas atiendan más a los modelos italianos que a Marcial. Pinhel, sin embargo, como hemos visto, no sólo conoció, sino que estudió al bilbilitano. Así lo demuestra la traducción de VIII 24, 1 (Si quid forte petam timido gracilique libello) en una octava castellana, una de las rarísimas versiones del latín originales que contiene el códice:

Si alguna cosa acaso te pidiere,

César, en verso heroico y delicado,

Si fuere justo, dala; $y$ si no fuere,

No la dieres, permite ser rogado,

${ }^{125}$ Lo reprodujo G. Vasari, Le vite dei più eccellenti pittori, scultori e architetti, Roma, 1991, p. 64.

${ }^{126}$ P. Honan, Shakespeare. A Life, Oxford, 1998, p. 403.

${ }^{127}$ Cf. L. Ruiz Fidalgo, La imprenta en Salamanca, II no 524 (p. 521). El epicedio se encuentra en todas las ediciones de Verino (así en la publicada en 1499 en Tarragona). 
5 Que el sacro Jove con incienso quiere

Y ruegos siempre ser sacrificado;

Que no es el hacer dioses esculpillos:

Rogallos, sí, pedillos, bendecillos ${ }^{128}$.

En la Universidad de Alcalá de Henares, de corte más filológico, Marcial sedujo a profesores y alumnos con su inimitable gracejo y sus aceradas sentencias, aunque posiblemente no dentro, sino fuera de las aulas: ya hemos visto el parecer dado por Gómez de Castro sobre los libros que debían prohibirse. En la impresión complutense del Liber fastorum de Juan Bautista de Mantua, publicado en 1520 y 1527, se reprodujo el famoso epigrama "de beata vita" (X 47) ${ }^{129}$. Más interés tiene para nosotros la afición que le mostró el helenista Francisco de Vergara, el hermano de Juan, afición bien patente en su Gramática griega, publicada en 1537. Ya en la epistola dedicatoria se encuentra una alusión velada a IX 97 ("Obstrepant licet ac rumpantur alieni laboris fuci") y una cita expresa a I 16. A continuación Vergara reproduce y traduce al griego el epigrama I 40, una hazaña que sólo emulará en nuestra patria muchos años más tarde el deán Martí130:

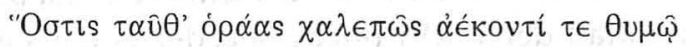

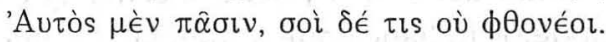

También Vergara trae a colación el testimonio de Marcial al tratar de la cantidad de las vocales, recordando cómo el poeta recurre al griego para alargar en IX 11, 13 la vocal inicial de 'E $\alpha \rho$ ı́ós (pp. 207-08) y cómo hace entrar ingeniosamente en el hexámetro, traduciéndola a medias, una palabra, myrobalanum (XIV 57, 2), que, por la secuencia de breves, no encaja en el ritmo dactílico (p. 208).

Un verdadero aluvión de poesías saludó la visita del nuevo arzobispo toledano, Juan Martínez Siliceo, a la Universidad complutense (1546), difamada ante el anterior primado (el cardenal Tavera) y deseosa de congraciarse con su sucesor, a quien recibió el claustro como a un Cisneros redivivo. Tanto los profesores ("eruditi homines") como los alum-

${ }^{128}$ Ms. RAH E-65 (ahora 9/5880), f. 83r.

129 J. Martín Abad, La imprenta en Alcalá de Henares (1502-1600), Madrid, 1991, I no 86 (p. 275).

${ }^{130}$ J. Martín Abad, La imprenta en Alcalá de Henares, I, nº 284 (p. 446). 
nos ("ingeniosi adolescentes") rivalizaron a porfía en componer odas, epigramas y poemas en griego y en castellano, ajustándose a las reglas promulgadas por el rector, Jorge Genzor, para poder competir en los cinco certámenes propuestos ${ }^{131}$. Con objeto de perpetuar tan fausta ocasión se imprimió un librito conmemorativo en el que, en un alarde tipográfico, hasta se reprodujeron en grabados las pinturas alegóricas que, adornando los arcos triunfales y acompañadas de sendos epigramas, acogieron a Silíceo como a un restaurador del Estudio. En el prólogo del mismo se pidió al egregio visitante que se mostrase benigno juez del esfuerzo realizado: no debía buscar en los poemas dactílicos la cabal majestad de la epopeya ni en los epigramas una gracia consumada. Ese lepor que se exige a los epigramas indica ya cuán lejos nos encontramos de Marcial, quizá olvidado diplomáticamente durante la estancia del prelado, que no era ni mucho menos un dechado de tolerancia.

Como se ve, también en la Universidad complutense se celebraron justas poéticas, que concedían al vencedor el título de poeta laureatus ${ }^{132}$. En la fiesta del Corpus de 1552 ganó el premio Benito Arias Montano con una oda sáfica sobre la Eucaristía, desarrollando el episodio bíblico del mal sacerdote Uzzá133. Pero, y esto es lo más curioso, además de esta lírica elevada, a la que se había de consagrar en exclusiva nada más alcanzar la madurez, Montano no dejó de cultivar en sus primeras salidas al Parnaso el epigrama: se trata de poemillas que acompañan el envío de un regalo (p.e., los cuchillos de Lancero) o bien cursan a un amigo una invitación a cenar. J. Pascual Barea ${ }^{134}$ ha querido ver en ellos un influjo de

${ }^{131}$ Publica laetitia, qua dominus Iones Martines Siliceus Archiepiscopus Toletanus ab Schola Complutense susceptus est, Alcalá, 1547.

${ }^{132}$ Un pregón de tales fiestas es el epigrama CCXXXIV de Álvar Gómez de Castro.

133 Desarrollado también en Rhet. I 420ss., cf. V. Pérez Custodio, "Un episodio bíblico como fuente de creación poética épica y lírica en Arias Montano", Excerpta philologica, I.2 (1991) 615ss.

134 "Un poema inédito de Arias Montano a Don Hernando de su etapa complutense influida por Marcial", Revista agustiniana, XIL (1998) 1017ss.; "Un epigrama inédito de Arias Montano basado en la epístola quinta de Horacio como invitación a un suculento almuerzo en Alcalá" en El humanismo extremeño (Primeras jornadas), Trujillo, 1997, p. 83ss.; "Ecos de las obras de Marcial y de Erasmo en un epigrama de Arias Montano durante sus estudios en Alcalá", Calamus renascens, I (2000) 259ss.; “Un epigrama de Benito Arias Montano con dos 
Marcial, más concretamente de los Xenia y Apophoreta. Es, sin duda, una atractiva y bien fundada sugerencia: los ecos son perceptibles sobre todo en la poesía dirigida a Serrano. No obstante, el parangón adecuado, a mi juicio, se ha de buscar en los epigramas coetáneos de otra lumbrera de Alcalá, Álvar Gómez de Castro, el mejor poeta de la Universidad complutense, que gustó asimismo de componer poesías para cumplimentar a su círculo de íntimos empleando los mismos temas: bien celebrando alguna donación propia (p.e. truchas [CCLVIII-CCLXI, CCCLXXXIVCCCXCI] o aceitunas [CCCLXIII]), bien invitando a una comida. Ahí está, a mi juicio, el modelo de Montano ${ }^{135}$, quien siguió el mismo esquema incluso en el epigrama más tardío dirigido a Juan Vélez de Guevara.

La fuente de Gómez de Castro y de Montano puede ser Marcial, indudablemente; más los dos temas se repiten hasta la saciedad en la Antología griega, libro trilladísimo por Castro, como hemos visto. $\mathrm{Y}$ bueno será confesar de una vez por todas que el carácter de Álvar Gómez no congeniaba del todo con la musa mordiente y salaz del epigramatista romano. Escasa es la huella de Marcial que se encuentra en otra obra suya, el Recebemiento que la Imperial Ciudad de Toledo hizo a la Magestad de la Reyna nuestra señora doña Ysabel, hija del Rey Henrrico .II. de Francia, quando nuevamente entró en ella a celebrar las fiestas de sus felicíssimas bodas con el Rey don Philippe nuestro señor, .II. d'este nombre (Toledo, 1561). En este docto librito se reconocen a las claras los préstamos tomados de Lucano o de Virgilio (f. 24r y v), pero sólo una vez se cita a Marcial, y ello para comparar las folías que hacían los niños, acompañándose del repiquetear de las sonajas, con los bailes de las puellae Gaditanae ${ }^{136}$, comparación que

cuchillos y un chiste sobre la Biblia para Cipriano de la Huerga" en Cipriano de la Huerga, Obras completas, León, vol. X (en prensa). Acompañar un regalo de poesías es práctica que remonta a los Xenia y Apophoreta de Marcial, como bien señala Pascual, a quien debo y agradezco el envío de estos artículos suyos, algunos de ellos todavía en prensa.

${ }^{135}$ En cambio, es curioso -y significativo- el silencio que ambos humanistas guardaron el uno respecto al otro. No parece que coincidieran en Alcalá, pero sin duda hubieron de conocerse.

${ }^{136}$ Los niños "podían hazer mil géneros de mudanças o folías (como aquella dança las llaman) con sonajas que llevavan en las manos... Creo que esta manera de bayle es del que ay memoria en Marcial en el libro sexto [la Telethusa de VI 71, 5]" (f. 16r). 
no deja de sorprendernos. Y es más: consultado por la Inquisición sobre "los libros así latinos como españoles que devían prohibirse o podían permitirse", el humanista incluyó entre los poetas reprobados a Marcial que, junto con Catulo y los carmina Priapea, habría de quedar proscrito de la enseñanza superior ${ }^{137}$. He aquí un juicio bien intencionado, sí, según los tiempos que corrían, pero que ponía en la picota a todos los clásicos latinos de un género literario.

La poca inspiración marcialesca que cabe encontrar en Gómez de Castro y en Montano brilla por su ausencia en Juan de Santa Cruz Cárcamo, canónigo de Burgos, que en 1553 editó muy ufano las composiciones de su propia Minerva que habían sido galardonadas en la Universidad complutense ${ }^{138}$. Son nueve poesías en total: cuatro glosas a pasajes del Nuevo Testamento en hexámetros y dísticos; dos recibimientos a la visita de Felipe II -el nuevo Apolo- a la Universidad de Alcalá (uno en dísticos, otro en falecios), dos odas a los santos Justo y Pastor (en metros horacianos: alcmanio y dístico yámbico, respectivamente) y un epigrama a $\mathrm{D}^{\mathrm{a}}$ Ana de Osorio, su protectora y bienchechora ${ }^{139}$. En el preámbulo Alfonso García Matamoros puso de relieve las cualidades poéticas de Cárcamo: imita a Virgilio en la graveza y majestuosidad y a Horacio en la armonía rítimica; además, impregna de verdadera piedad los hendecasílabos, metro que Catulo, pensando en ablandarlo, lo adobó con perniciosa lascivia ("quos non putauit Catullus posse molliri nisi lasciuiae per-

137 Cf. L. Gil, Panorama social del humanismo español (1500-1800), Madrid, 1981, p. 519.

138 Versus qui Compluti lauream meruerunt, a Ioanne de Sanctacruce Carcamo, ecclesiae Burgensis canonico et Aeditimo primario compositi, quos D. Annae de Osorio praestantissimae et pudentissimae foeminae dicatos voluit, Compluti, 1553.

${ }^{139}$ He aquí su transcripción:

Quae foret huic similis nullam tu, Roma, tulisti,

Nullam consilio nec grauitate parem.

Sint aliae fortes, laudentur fortia facta:

Tu pietate vales atque pudicitia.

Infima nec laus est sacram coluisse Mineruam

Et sacros libros voluere mente pia.

Nam genus et proauos claros repetitaque longè

Stemmata quis nescit, foemina magna, tuum?

Non tulit omne aeuum similem, nec post feret ulla

Posteritas, sexus gloria sola tui. 
nitioso condimento"); en cambio, los falecios de Cárcamo son todos castos, sublimes unos al remontarse con grandeza heroica, dulces otros sin empalagosidad y muelles sin lascivia ("casti omnes, et partim, cum te vis attollere, heroica granditate sublimes, partim sine fastidio dulces et sine libidine molles"). En esta alabanza se echa de ver cuáles eran los tres poetas apreciados por el canónigo: Marcial, desde luego, no sale favorecido. Después, conocemos los poemas, siempre de tema sagrado, dedicados a la traslación de los restos de San Eugenio (1566) y de San Justo y San Pastor (1568) y a la beatificación del sevillano San Diego de Alcalá (1589), recibida con júbilo inmenso en toda España ${ }^{140}$. En el s. XVII, sin embargo, se fue imponiendo el romance en las justas poéticas celebradas con motivo de una canonización: así en ocurrió en las fiestas de Santa Teresa ${ }^{141}$ y de San Francisco Javier $(1622)^{142}$, sin que el latín desapareciera del todo en estas efusiones líricas.

A todos los epigramatistas del s. XVI superó el alcañizano Domingo Andrés († d. de 1594); al menos en número de composiciones. Huellas de Marcial se encuentran por doquier en sus versos, que tienen a veces el aguijón necesario dentro de los límites del pudor (cf. LVII). Como Marcial tuvo Andrés una finca en las afueras, con todos los inconvenientes del campo y sobre todo con la importunidad de un vecino (LIV); como Marcial se burló el aragonés de médicos, maestros, músicos, ambiciosos y maledicientes, aunque otras veces fuesen los pueblos vecinos el objeto de la sátira: así ocurre en la encarnizada caza que dieron los de Morella a un gato, tomándolo por una zorra (LXXXVII). Como Marcial recibió Andrés

${ }^{140}$ Cf. Fr. Gabriel de Mata, Vida y muerte y milagros de San Diego... con los Hierogliphicos y versos que en alabança del Sancto se hicieron en Alcalá, Alcalá, 1589. Cf. asimismo F. Pegna, De vita, miraculis et actis canonizationis Sancti Didaci libri tres, Roma, 1589 ( in epigramas).

${ }^{141} \mathrm{Cf}$. las Fiestas que el Convento de Nuestra Señora del Carmen de Valencia hizo a nuestra Santa Madre Teresa de Jesús, a 18. de octubre, 1621, Valencia, 1622. Las organizó fray Manuel Mendoza, portugués de Lisboa, sacristán mayor del mismo convento, quien "por los méritos d'esta santa quedó sano de una grande enfermedad que padecía" (p. 7). El certamen poético se celebró el 28 de octubre de 1621; el secretario fue Guillén de Castro (aunque por el vejamen se ve que Castro tuvo que ausentarse a Madrid). Todas las poesías están en castellano, menos una, en catalán, que se atribuye a "un llavrador del Orta".

142 Cf. I. Elizalde, San Francisco Xavier en la literatura española, Madrid, 1961, p. 235ss. 
regalos, en este caso de sus alumnos. J. Mª Maestre, al rescatar del olvido total las poesías de Andrés, ha señalado con suma agudeza esta vena marcialesca, quiza exagerada adrede por el propio poeta ${ }^{143}$.

Por otra parte, nuestro poeta sirvió de fuente de inspiración en las obras de encargo, cuando se levantaban en conmemoración de un suceso obras de arquitectura efímera y a los humanistas les tocaba componer los epigramas que iban a adornar los arcos de triunfo, túmulos, etc. Los ejemplos abundan.

Para celebrar las honras fúnebres del Papa Paulo III (1549) el cardenal Silíceo levantó en Toledo un imponente cenotafio, que fue muy celebrado a su vez por Álvar Gómez de Castro (CXL-CXLII). El mismo Álvar Gómez compuso varios epigramas (CCXXXVII-CCXL) para las exequias que la ciudad de Toledo hizo a Juana la Loca (1555).

A la muerte de Carlos V (1559) se erigió en la capital de la Nueva España un imponente catafalco, descrito en la obra intitulada Túmulo imperial de la gran ciudad de México. El oidor Alonso de Zurita, en la carta antepuesta a la publicación, citó a Marcial, Spect. I 7-8 ${ }^{144}$.

Alcalá de Henares mostró muy solícita su lealtad a Felipe II en Las fiestas con que la Universidad de Alcalá alçó los pendones por el rey Don Phelipe, nuestro señor y en el Recebimiento que la Universidad de Alcalá hizo a los reyes, nuestros señores, quando vinieron de Guadalajara tres días después de su felicíssimo casamiento, folletos que corrieron de molde en las prensas de Juan de Brocar en 1556 y 1560, respectivamente, uno y otro con buen número de epigramas conmemorativos. El gran humanista Álvar Gómez de Castro, que tanta mano tuvo en la composición de los epigramas alcalaínos, redactó también el Recebemiento (1561) del que ya se ha hablado.

En 1569 se encomendó a Juan de Mal-lara el proyecto iconográfico de la galera real que había de combatir en Lepanto. El humanista sevillano hizo un considerable esfuerzo por allegar simbología de muy diversas fuentes, desde Alciato a Pierio Valeriano, autor que le suministró material para hacer los jeroglíficos entonces tan de moda; pero buena parte de epigramas está compuesta en dísticos, "como los

143 Poesías varias del alcañizano Domingo Andrés, Teruel, 1987, p. XL.

144 J. García Icazbalceta, Bibliografía mexicana, edición corregida por A. Millares Carlo, México, 1954, p. 162. 
presentes de Marcial en sus Xenias y Apophoretas"145. También se deja sentir el influjo del bilbilitano en la obra que compuso Mal-lara para celebrar la entrada en Sevilla de Felipe II $^{146}$. Era lógica esta huella en la producción latina del sevillano, que ya había publicado traducciones de los epigramas de Marcial, alardeando de ser el primero en hacerlo, en una obra anterior escrita en romance, la Philosophía vulgar (Sevilla, $1568)^{147}$.

El túmulo erigido en 1579 a la apertura de la Capilla Real hispalense fue engalanado con epigramas del licenciado Francisco Pacheco, a mi gusto el mejor poeta de la Sevilla finisecular. Sin embargo, Pacheco, como su amigo Arias Montano, fue más admirador de Virgilio y de Horacio que de Marcial; no hallo reminiscencias del bilbilitano en estos epigramas ${ }^{148}$ ni tampoco en los que compuso para la nueva sacristía de la catedral.

Las exequias celebradas en honor de Felipe II fueron solemnísimas. Todas las ciudades de España rivalizaron por aventajarse en pompa y boato, elevando sendos catafalcos de los que se conservan descripciones de los de Sevilla, Murcia ${ }^{149}$, Zaragoza ${ }^{150}$ y México ${ }^{151}$, con sus correspondientes poesías alegóricas.

La agudeza y brevedad del epigrama vinieron como anillo al dedo a la emblemática y a su hermano el jeroglifo, pues en el emblema el epigrama (la subscriptio) desarrolla el concepto expresado por la pictura. Pero puede ocurrir también que la empresa, divisa o letra (la inscriptio) esté tomada de un epigrama. Res est magna tacere (Mart. IV 81, 6) fue una de

${ }^{145}$ Cf. R. Carande, Mal-lara y Lepanto, Sevilla, 1990, p. 227.

${ }^{146}$ Recebimiento que hizo la muy noble y muy leal ciudad de Sevilla a la C.R.M. del rey D. Philipe N.S., Sevilla, 1570.

${ }^{147}$ Las traducciones fueron recogidas convenientemente por Menéndez Pelayo, Bibliografía hispano-latina clásica, Madrid, VII, 1951, p. 107.

148 Cf. B. Pozuelo, "El túmulo erigido en Sevilla a la apertura de la nueva Capilla real (1579), obra emblemática del licenciado Francisco Pacheco", Excerpta philologica, III (1993) 349ss. Pozuelo señala algunos loci similes de Marcial, que me parecen bastante lejanos.

149 Las reales exequias y doloroso sentimiento que la muy noble y leal ciudad de Murcia hizo, Valencia, 1600.

${ }^{150}$ Relación de las exequias que la muy insigne ciudad de Çaragoça a celebrado por el Rey Doin Philipe, nuestro señor, Zaragoza, 1599.

${ }^{151}$ J. García Icazbalceta, Bibliografía mexicana del siglo XVI. Nueva edición por A. Millares Carlo, México, 1954, p. 442ss. 
las inscriptiones propuestas por D. Juan de Borja, conde de Mayalde y de Ficallo, hijo de S. Francisco de Borja ${ }^{152}$. La pictura (sin subscriptio) es un medallón con la cabeza de Tántalo, castigado por haber hablado en exceso, teniendo el agua y la fruta al borde de los labios. "Pues muchas vezes, por hablar, se ha dexado de salir con cosas que al parecer estavan cerca de alcançarse, quanto la fruta y el agua lo están de la boca de Tántalo".

De otro Borja, Pedro Luis Galcerán de Borja, fue amigo el "Marcial de Valencia", como llamó Baltasar Gracián a Jaime Juan Falcó153. Mas otra vez nos llevamos un chasco: Falcó, cuyo modelo en poesía es sin duda Virgilio, está más próximo a la Antología griega (cf. las claras imitaciones $55=$ VI 1; 18-20; 78 = XVI $174+$ Aus. Epigr. 64; $99=$ XVI 201; $118=$ IX $430)^{154}$ que a Marcial.

152 Empresas morales, Bruselas, 1680, p. 196. El emblema pertenece a la primera parte de la obra, editada en 1581 en Praga. En cambio, no hay divisas tomadas de Marcial en los Emblemas morales de Don Juan de Horozco y Couarruuias, Arcediano de Cuéllar en la santa Yglesia de Segouia, dedicadas a la memoria del Presidente Don Diego de Couarruuias y Leyua, su tío (Segovia, 1589) ni en los Emblemas moralizados de Hernando de Soto (Madrid, 1599). El primero hace alusión a Marcial en I, f. 20r (alusión a pegmata celsa uia de Spect. II 2), f. 93v ("dixo Marcial [IV 66, 10] que el fuego estaua rodeado de la corona que le ceñía", II f. 37v (uendere... fumos [IV 5, 7]). El segundo menciona al epigramatista sólo dos veces (f. $96 \mathrm{r}$ : crueldad de Nerón, asesino de Lucano, "bien exagerada por Marcial [VII 21], pues le haze por ella más aborrecible que las mismas almas del infierno"; f. 107v = I 3 "la mayor lisonja que Marcial [I 3, 12] pudo hazer a Iulio César [en realidad, a Domiciano] fue el llamarlo verdadero padre de la patria"), y eso que uno de sus emblemas, Producit Hispania Scaeuolas (f. 23ss.), se prestaba a las mil maravillas a desplegar otra cita erudita. Tampoco hallo rastro alguno de Marcial en los Emblema centum regio-política de Juan de Solórzano Pereira (Madrid, 1653).

${ }_{153}$ Agudeza y arte de ingenio en que se explican todos los modos y diferencias de conceptos, en Obras de Lorenzo (sic) Gracián, Discurso XIX (Barcelona, 1669, II, p. 109): "El Marcial de Valencia, aquel que tuvo sin duda algún rayo por ingenio, pues en todas las artes y ciencias (que fue universal) afectó siempre lo más dificultoso". En el Discurso XXI lo calificó de "más agudo que culto" (p. 121), en el XXIX de "Falcón en la sutileza y Cisne en los conceptos" (p. 180), en el LIV de "aquel que tuvo alas en el ingenio" (p. 290) y en el LIX: "su autor dexó de ser Falcón y se transformó en Águila" (p. 317).

${ }^{154}$ Cf. la espléndida edición de D. López-Cañete, Jaime Juan Falcó. Obras, I, León, 1986. 


\section{Imitaciones en castellano}

No es mi propósito entrar en este tema, que ha sido tratado con gran solvencia por varios autores ${ }^{155}$. Me limitaré a señalar otra vez, a riesgo de ser repetitivo, que el espíritu del epigrama romano tardó mucho tiempo en aclimatarse en la literatura castellana del s. XVI. Es bien conocido que Marcial (Spect. 25) fue el modelo de Garcilaso en el poema sobre Hero y Leandro ${ }^{156}$. Mas nada hay más diferente que las dos poesías: los cuatro versos de Marcial se transforman en catorce, dando al traste con la concisión que se exige a este género. En verdad, el único parecido, fuera del tema general, estriba en el empleo del soneto, equiparado al epigrama tal y como habían propugnado algunos teóricos italianos ${ }^{157}$ y recordaron

155 Cf. entre otros V. Cristóbal, "Marcial en la literatura española", Actas del Simposio sobre Marco Valerio Marcial, poeta de Bílbilis y de Roma, Zaragoza, 1987, II, pp. 145-210. F. Schalk, "Quevedos 'Imitaciones' de Marcial", Festschrift für H. Thiemann, Hamburgo, 1959, pp. 202-12; S. Parga y Pondal, "Marcial en la preceptiva de Baltasar Gracián", Rev. Arch. Bibl. Mus., LI (1930) 219ss. Por desgracia, me ha sido inaccesible el libro de A. A. Giulian, Martial and the Epigramm in Spain in the Sixteenth and Seventeenth Centuries, Philadelphia, 1930, sin duda el estudio más completo sobre el tema.

156 Así lo observó ya Gracián, Agudeza y arte de ingenio, Discurso XXXV, p. 210, que inserta una traducción de Miguel de Salinas en una décima. Cf. asimismo M. Menéndez Pelayo, Bibliografía hispano-latina clásica, VII, p. 146ss. Sobre la influencia anterior de este epigrama de Marcial (y de las Heroidas de Ovidio) en Juan Ruiz de Corella cf. ahora Ll. Lucero Comas, "La tradició ovidiana en l'obra de Joan Roís de Corella: una aproximació parcial" y sobre todo E. Trilla Millás-V. Cristóbal López, "Las Heroidas de Ovidio en Joan Roís de Corella", en Tradició Clàssica. Actes de l’XI Simposi de la Secció Catalana de la S.E.E.C. St. Julià de Lòria-La Seu d'Urgell, 20-23 d'octubre de 1993, Andorra, 1996, p. 437ss. y 693ss. respectivamente y especialmente p. 696. Lo mismo viene a decir de manera un tanto enrevesada y críptica A. Melero ("El Hero y Leandro de Boscán o el mito como poética" en I. García Gálvez (ed.), Grecia y la Tradición clasica, La Laguna, 2002, II, p. 547).

157 Así, p.e., Lorenzo de Médicis: "La brevità del sonetto non comporta che una sola parola sia vana, e il vero subietto e materia de' sonetti, per questa raggione, debba essere qualche acuta e gentile sentenzia, narrata attamente e in pochi versi ristretta, fuggenda la obscurità e durezza. Ha grande similitudine e conformità questo modo di stile con lo epigramma, quanto allo acume della 
más tarde T. Sebillet ${ }^{158}$, F. de Herrera ${ }^{159}$ y Juan Díaz Rengifo ${ }^{160}$. Después Gutierre de Cetina, al abundar en el mismo asunto en otro soneto, compitió más con Garcilaso que con Marcial, como advirtió el mismo Herrera ${ }^{161}$; y en sendos sonetos trasladaron asimismo el original latino Juan de Coloma (1554), Da Hipólita de Narváez (1605) y el licenciado Juan de Valdés (1605) ${ }^{162}$. Mas tampoco fue más feliz la versión del propio Herrera, que se prolonga de manera innecesaria en un romance octosílabo de 16 versos $^{163}$. Hay que tener en cuenta, sin embargo, que muchas veces, contra lo que podría esperarse, no se unía la brevedad con el concepto de epigrama, a pesar de lo que pregonaban los preceptistas antiguos y modernos (Alonso López Pinciano, p.e.); como señala

materia e alla destrezza dello stile, ma è degno e capace il sonetto di sentenzie più gravi, e però diventa tanto più difficile" (Commento de' miei sonetti en Lorenzo de' Medici. Opere, ed. de T. Zanato, Turín, 1992, p. 586).

158 Art poëtique françoys, París, 1548. Utilizo la edición crítica de F. Gaiffe, París, 1910, p. 115.

159 Obras de Garcilasso de la Vega con anotaciones de Fernando de Herrera, Sevilla, 1580, p. 66: el soneto "sirve en lugar de los epigramas i odas griegas y latinas i responde a las elegías antiguas en algún modo". Un "epigramma LatinoHispanicum vulgò soneto" de D. Francisco de Alarcón cantó las alabanzas del De Indiarum iure de Juan de Solórzano Pereira (segundo volumen, Madrid, 1639). G. Colletet, en su Traitté du Sonnet, Paris, 1658, p. 4 observó que "le fameux" Lope de Vega había dado el título de epigrama a un soneto de Selvagio (en realidad, de Montano) en su Arcadia (BAE 38, p. 98 a). Cf. J. Nowicki, Die Epigrammstheorie, p. 25-26 y n. 6, 50ss., 63: el epigrama y el soneto son parangonados solamente por virtud de su indefinición, tanto desde el punto de vista del contenido como del estilo.

160 Arte poética española, cap. XLII (ed. de Madrid, 1644, pp. 48-49): "Sirue... finalmente para todo aquello que siruen los epigramas latinos". Como es sabido, Baltasar Gracián atribuyó la obra al hermano de Rengifo, un padre jesuita (Agudeza y arte de ingenio, Discurso XXXI, p. 195).

161 Obras de Garcilasso de la Vega, p. 204 (cf. Menéndez Pelayo, Bibliografía hispano-latina clásica, VII, p. 157).

162 Todos ellos recogidos por Menéndez Pelayo (Bibliografía hispano-latina clásica, VII, p. 146ss.). En un soneto tradujo Lope de Vega el epigrama X 47 de Marcial (cf. J. Nowicki, Die Epigrammstheorie, pp. 30-31).

${ }_{163}$ Obras de Garcilasso de la Vega, pp. 201-02. 
Nowicki, los epigramas antiguos y los españoles tuvieron en común la variedad tanto de formas como de contenidos ${ }^{164}$.

Según indicó Th. K. Wipple, en la última década del siglo XVI se produjo en Inglaterra una reacción, capitaneada por J. Donne y B. Jonson, contra los cánones literarios dominantes hasta entonces. Fue una época propicia a Marcial, un "tiempo de desilusión y escepticismo, sofisticado y cínico"165, que alumbró al mejor epigramatista en lengua vernácula, Ben Jonson, émulo de nuestro poeta pero tomándose con más seriedad su papel $^{166}$. Lo mismo podría decirse de España, y por las mismas razones: el XVII fue el siglo de mayor esplendor de la poesía epigramática española, que intentó cristianizar a Marcial, limando en lo posible sus obscenidades. El barroquismo, sin embargo, tan favorecedor del epigrama y ello en sus dos vertientes (culteranismo y conceptismo), supuso un obstáculo para la imitación de Marcial, más clasicista. También supuso una traba la excesiva genialidad. La propia exuberancia de su ingenio le impidió a Quevedo, p.e., un hombre superdotado para la poesía satírica, contenerse en sus justos términos. Dicha una agudeza, Quevedo la sigue, la persigue, le da mil vueltas, la marea. Su espíritu, que se parece mucho al de Juvenal, procede más por acumulación ingeniosísima de agudezas y genial retorcimiento del lenguaje que por la desnuda exposición de una gracia. Y de esta pasión por Juvenal (y por Persio) son buena muestra no pocos de los sonetos quevedescos, mientras que el número de poesías inspiradas por Marcial es mucho más reducido ${ }^{167}$.

En la imitación de los antiguos impone sus reglas el metro. Un poeta cultísimo como Bartolomé Leonardo de Argensola utiliza los tercetos como vía de expresar sus afectos, humores, pensamientos; ése es el molde

164 J. Nowicki, Die Epigrammstheorie, p. 17 y 32.

${ }^{165}$ Martial and the English Epigram from Sir Thomas Wyatt to Ben Jonson, University of California Publications in Modern Philology, Vol. X No. 4, 1925, p. 337.

166 En cambio, la ironía de las comedias de Jonson deriva de Erasmo, Moro y sobre todo de Luciano, cf. al respecto Douglas Duncan, Ben Jonson and the Lucianic tradition, Cambridge, 1979.

167 Sobre Marcial y Quevedo cf. P. J. Galán, "Censura moral en las Imitaciones de Marcial de Quevedo" en A. M. Aldama Roy et alii (eds.), La Filología Latina hoy: actualización y perspectivas, Madrid, Sociedad Española de Estudios Latinos, 1999, II, pp. 953-965. 
de las epístolas morales, en las que, además del omnipresente Horacio, de nuevo se hace sentir poderoso el influjo juvenaliano: de Marcial sólo hay una cita directa en Rimas 49, 109ss. ${ }^{168}$. El epigrama se vierte por lo general en su forma predilecta, el soneto: así, y con mención expresa de Marcial (V 29; contra Gelia), en Rimas 69 (ed. de J. M. Blecua, Clás. Cast., I, p.175); otras imitaciones, también en soneto, hizo Argensola en Rimas 56 (ed. de J. M. Blecua, Clás. Cast., I, p. 166) = II 41 (contra Maximina) y 70 (I, p.176) = XII 61 (contra Ligurra). En cambio, para las traducciones propias el aragonés, como Baltasar del Alcázar, se sirvió de la octava, la décima, la redondilla y la quintilla (Rimas $197=\mathrm{IX} 15 ; 198=\mathrm{I} 19 ; \mathrm{XXXI}=\mathrm{V}$ 29; XXXII = II 9), estrofas más vulgares que utilizó asimismo de manera preferente el canónigo Miguel de Salinas para las suyas, según veremos.

\section{El arte epigramático y la Compañía de Jesús}

Como bien ha recordado Hoyt Hopewell Hudson ${ }^{169}$, el epigrama es una pieza fundamental en la educación escolar del Quinientos. No es ningún azar que John Owen, un maestro de escuela, se convirtiera en epigramatista ni tampoco que, justamente por ello, fuera uno de los más leídos y trasladados a varias lenguas, entre ellas el castellano (Agudezas de Iuan Ouen, traducidas... por Francisco de la Torre, Madrid, 1674-1682). Los maestros enseñaban a los adolescentes a hacer versos latinos mediante la composición de epigramas. Una de las maneras de proceder en clase era proponer el título o lema de la poesía, que el alumno debía desarrollar de manera satisfactoria.

Desde su inicio la Compañía de Jesús tuvo claro que uno de los frentes principales de su actuación en la sociedad cristiana habría de ser la enseñanza. En un plazo de tiempo increíblemente corto la Compañía

168 "Queriendo proseguir, llegó un amigo, / Y dijo: "¿Los poetas no podrían / Llevar a vueltas d'esto su castigo?" / Con Marcial respondí: "Dicha tendrían, / Mas libre Dios mi libro d'esa sarna, aunque ellos merecido lo tenían" (Ed. J. M. Blecua, Clás. Cast., I p.157). Imita Argensola la negativa de Marcial a criticar a los poetas enemigos (V 60).

169 The Epigram in the English Renaissance, Princeton, 1947. El capitulo cuarto del libro está dedicado a estudiar la fortuna del epigrama en las escuelas y colegios. 
levantó Colegios en todos los continentes, de suerte que disciplinas como la Retórica y las Humanidades tuvieron maestros jesuitas en México y en Lima, en Goa y en Macao; y es de notar que en los territorios ultramarinos portugueses no hubo Universidad que hiciera competencia a la Compañía que, consiguientemente, pudo campar por sus respetos sin que nadie le chistara, omnipresente e invicta hasta Pombal.

La filosofía de la Ratio studiorum ${ }^{170}$ se basa en unos principios pedagógicos muy simples, pero muy efectivos, dando por descontado que en esta época el pilar de la enseñanza era el latín, lengua en la que se introducía al alumno desde muy niño ${ }^{171}$. En primer lugar, conviene fomentar la memoria. En segundo término, es preciso espolear la agudeza y la inteligencia. En tercer lugar, es necesario estimular la emulación, dentro de unos límites. Para fomentar la buena rivalidad está la disputa, el certamen: concertatio... usurpanda, ut honesta aemulatio, quae magnum ad studia incitamentum est, foueatur. Pregunta el maestro, interrogan y corrigen los condiscípulos; a veces se forman grupitos que compiten entre sí. La excelencia hay que recompensarla con premios, y ello desde las clases primarias: en los días más festivos dos alumnos elegidos por el rector colocan públicamente emblemas y poesías, leyéndose todas las composiciones y eligiéndose las mejores ${ }^{172}$. Para el alumno más avanzado se establecen ocho premios de Retórica, entre ellos dos de poesía latina y otros dos de poesía griega ${ }^{173}$.

En este tipo de educación juega un papel fundamental la poesía. En efecto, el verso es más fácil de memorizar que la prosa, proporciona un amplio caudal léxico al alumno, ejercita su imaginación y en determina-

${ }^{170}$ Utilizo la edición Ratio atque institutio studiorum Societatis Iesu, Neapoli, 1598 (pero el prefacio del secretario Jacobo Dominico está fechado en Roma el 8 de enero de 1599). Es curioso ver cómo, entre unas reglas pedagógicas bastante avanzadas, se mantiene un férreo control ideológico. Así ocurre p.e. en las reglas del profesor de filosofía, al que se le exige: "In rebus alicuius momenti ab Aristotele non recedat, nisi quid incidat a doctrina, quam Academiae ubique probant, alienum, multo magis si orthodoxae fidei repugnet" (2 p. 81).

${ }^{171}$ En las clases inferiores había ya una praelectio o un ejercicio en griego o en latín (prosa o poesía) en Retórica y Humanidades un sábado sí y otro no, según mandan las reglas a los profesores de las clases inferiores, 33 (p. 127).

172 Reglas del prefecto de los estudios inferiores, 3 (p. 93).

${ }^{173}$ Premios, 1 (p. 113). 
dos casos -tragedia y comedia, textos dialogados- puede representarse. Ahora bien, no todos los poetas son asequibles e inocuos: es preciso tener mucho cuidado con las poesías escabrosas, demasiado sensuales o definitivamente amorales para el criterio ignaciano. Por tanto, y en ello se insiste ya desde las reglas del provincial, los textos de los poetas han de sufrir una purga previa; y si esto no se puede lograr de una manera satisfactoria, como ocurre en el caso de Terencio, más vale dejar de leerlos que ofender la inocencia de los niños ${ }^{174}$. Por otra parte, las tragedias y las comedias han de estar exclusivamente en latín, y no puede haber en ellas un personaje femenino ${ }^{175}$; ello explica la necesidad -y la consiguiente proliferación- de las comedias escritas por jesuitas para la enseñanza.

Veamos ahora cómo se fomenta la inteligencia, la capacidad lingüística y la agudeza del alumno en los dos campos de Retórica y Humanidades, dejando a un lado los estudios de Teología. En la clase de Retórica se enseña oratoria y poética, pero siempre dando preferencia, como es natural, a la primera, en la que prevalece el estudio de Cicerón, el preceptor máximo del estilo ${ }^{176}$. En la primera hora de la mañana, mientras el profesor se dedica a corregir los trabajos de los alumnos, éstos hacen ejercicios, como p.e., imitar un pasaje de un poeta o un orador; describir un jardín, un templo, una tempestad, etc., variando de estilo cada vez; traducir un texto griego, de prosa o de verso, en prosa latina; cambiar de forma una poesía; componer epigramas, inscripciones y epitafios; escoger frases griegas o latinas de buenos oradores y poetas; ajustar las figuras retóricas a ciertas materias; sacar de los lugares retóricos y tópicos argumentos para un asunto cualquiera ${ }^{177}$.

${ }^{174}$ Regla del provincial 34 (p. 16).

175 Regla del rector 13 (p. 24). Cf. L. Gil, Panorama social del humanismo español, p. 536ss.

176 Reglas a los profesores de retórica, 1 (p. 133); 6 (p. 137).

177 "Exercitationes discipulorum, dum scripta magister corrigit, erunt exempli gratia locum aliquem poetae uel oratoris imitari; descriptionem aliquam ut hortorum, templorum, tempestatis et similium efficere, phrasim eandem modis pluribus uariare; Graecam orationem Latine uertere aut contra; poetae uersus tum Latine tum Graece soluto stylo complecti; carminis genus aliud in aliud commutare; epigrammata, inscriptiones, epitaphia condere; phrases ex bonis oratoribus et poetis seu Graecas seu Latinas excerpere, figuras rhetoricas ad certas materias accommodare; ex locis rhetoricis et topicis plurima ad rem 
Especial hincapié se pone en la composición, tanto en prosa como en verso. En este último caso, a los alumnos se les puede entregar por escrito o de palabra el argumento de la poesía a componer, señalando sólo el tema o añadiendo una determinada sentencia; dicha poesía puede ser o bien breve (un epigrama, una oda, una elegía o una carta) para hacerla de un tirón, o bien larga, para componer un poema en varias sesiones, como se haría con un discurso; y lo mismo en griego ${ }^{178}$. En la concertatio los alumnos han de interpretar, entre otros temas, jeroglíficos, símbolos pitagóricos, apotegmas, emblemas y enigmas ${ }^{179}$. En la clase de griego se enseñan en el primer semestre historiadores y oradores; pero una vez a la semana el profesor puede intercalar algunos epigramas o poesías breves;

quampiam argumenta depromere, et alia generis eiusdem" (Reglas al profesor de Retórica, 1, p. 134 y 5 p. 137). A este texto parece referirse Hutton (The Greek Anthology in Italy to the Year 1800, Cornell Studies in English XXIII, Ithaca Nueva York 1935, p. 44), cuando señala que en las prelecciones griegas el maestro introducía nuevos epigramas una vez a la semana. En los días de vacaciones la prelección abordaba temas más abstrusos como jeroglíficos y emblemas, o discutía un género: epigrama, epitafio, oda, elegía. Los mejores poemas son mostrados en el tablón cada dos meses.

El jesuita Campion, educado en Winchester, enseñaba de la siguiente manera en la Praga del 1574, aplicando ya las reglas de la Ratio studiorum: Hacía primero que los niños repitieran un pasaje que habían aprendido por su cuenta; después los monitores recogían los ejercicios escritos, que miraba y corregía. Mientras tanto, los niños trataban de imitar un pasaje de un poeta o de un orador que les había puesto de ejemplo, o hacer una breve descripción de un jardín, una iglesia, etc.; escribir la frase de todas las maneras posibles; traducirla de una lengua a otra; componer versos griegos o latinos; pasar de un metro a otro; redactar epigramas, inscripciones, epitafios; reunir frases de buenos autores; aplicar las figuras de la retórica a tema dado; reunir todos los tópicos que le pudieran ser aplicados (cf. Hoyt Hopewell Hudson, The Epigram in the English Renaissance, Princeton, 1947, p. 152).

178 "Carminis etiam argumentum aut scripto aut verbo uel solam significando rem uel certa adiecta sententia tradi potest, idque aut breue, ut Epigrammatis, Odae, Elegiae, Epistolae, quod singulis uicibus expediatur; aut longius, ut pluribus uicibus, quemadmodum orationem, sic poema contexant" (Regla 10-11, p. 139).

179 Regla 12, p. 140. 
en el segundo semestre se explica un poeta, intercalando de la misma manera un prosista.

En el día de vacación en vez de un histórico o un poeta se puede discutir en clase de cosas más recónditas y de algunas cuestiones concernientes al artificio poético (quaestiones ad artificium poeticum spectantes) sobre epigramas, epitafios, odas, elegías, epopeya y tragedia ${ }^{180}$. Una vez al mes en el aula o en la iglesia se recita un discurso o una poesía, ya en griego, ya en latín. Las poesías mejores se ponen en las paredes de la escuela en meses alternos para celebrar un día festivo o el nombramiento de magistrados ${ }^{181}$.

En la clase de Humanidades se enseña Poesía: se estudia sobre todo a Virgilio, salvo las Églogas y el libro cuarto de la Eneida, pero también a Horacio (algunas Odas escogidas), así como Elegías y epigramas ${ }^{182}$. Igual que sucede en la clase de Retórica, mientras corrige el maestro los alumnos se ejercitan escogiendo frases y escribiéndolas de manera diferente, redactando un período a la manera ciceroniana, componiendo versos, cambiando de género un poema, imitando un pasaje o haciendo pinitos de griego ${ }^{183}$. En los días de vacación la segunda hora se dedica a que el alumno recite de memoria un epigrama, una oda o una elegía ${ }^{184}$. Las mejores poesías, como siempre, se exponen en la pared ${ }^{185}$.

Huelga decir el importantísimo papel que jugó en la Ratio studiorum la composición de epigramas, un género de poesía que tenía tres ventajas fundamentales desde el punto de vista pedagógico: brevedad, claridad y agudeza. Todo ello lo reunía en grado superlativo Marcial. Vistas sus excelencias, era imposible dejar de lado a un autor tan aprovechable por la claridad y pureza de su lengua, su gracejo y, en definitiva, por ser tesoro inagotable de noticias sobre la vida cotidiana romana, si bien despojándolo previamente para uso escolar de todas las obscenidades que empañaban su obra a juicio de los moralistas. Ya en 1519 un alemán, Hermann Busch, hizo una primera selección de treinta epigramas de Marcial con este objeto: no convenía despreciar las bondades del poeta

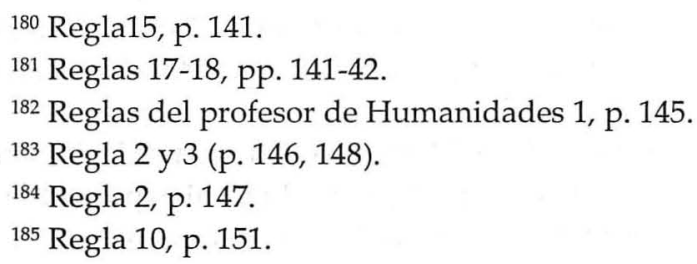


porque entre sus obras hubiera algunas malas acrecencias ("non conuenit, quae optima sunt, propter mala quaedam admixta penitus relinqui"), sino que había que libar lo más selecto, al modo de la abeja. El comentario esta tomado por lo general del de Demetrio Calderini, dando a veces el orden lógico de la frase ("sic ordina", "ordina sic"). Y Busch, que era asimismo un hombre chapado a la antigua, no pudo por menos de censurar las costumbres de sus propios compatriotas, criticando muy especialmente su inmoderada inclinación a la bebida ${ }^{186}$.

El camino a seguir estaba indicado ya. Sólo hacía falta poner manos a la obra, y preciso es confesar que los jesuitas no necesitaban estímulos para trabajar187. En 1558, "in aedibus Societatis Iesu", apareció en Roma el primer Marcial completo expurgado para uso de la Compañía (M. Valerii Martialis Epigrammata paucis admodum vel reiectis, vel immutatis, nullo Latinitatis damno, ab omni rerum obscenitate, verborumque turpitudine vindicata). Realizó la ingente tarea Andreas Frusius (de Freux), "diuinae charitatis ardore succensus et grauissimo eruditissimorum uirorum consilio et autoritate permotus", que murió antes de ver impresa su obra, en 1557, según indica en la epístola introductoria Emundus Augerius (Auger) ${ }^{188}$. El ejemplo fue imitado en todas las escuelas jesuíticas. El 16 de febrero de 1577 el virrey de la Nueva España, D. Martín Enríquez, dio licencia al Colegio de San Pedro y San Pablo de México para imprimir en los torculos de Antonio Ricardo los autores que pudiera necesitar para uso de los alumnos: allí están los poetas consabidos (fábulas, Catón, Bucólicas y Geórgicas de Virgilio, las Tristia y Ex Ponto de Ovidio, Miguel Verino),

${ }^{186}$ La tirada contra sus compatriotas (B iij) se encuentra en el comentario al epigrama sobre Acerra (I 39): "Nostra autem aetate et in nostra Germania ea [intemperantia] adeo inoleuit dudum, ut inter praecipua beneuolentiae certamina habeatur. Neque putant se nostrates cum amico humane et amice agere, nisi ita uino eum obruerint, ut hominem se esse penitus obliuiscatur".

187 Sobre la recepción de Marcial en la epigramática jesuítica y las contrahechuras a lo divino cf. sobre todo D. López-Cañete, "Sobre el epigrama religioso en el Renacimiento", Humanismo y pervivencia del mundo clásico. Homenaje al Profesor Luis Gil, Cádiz, 1997, II 2, p. 871ss.

${ }^{188}$ La edición lleva también la vida de Marcial compuesta por Pedro Crinito. C. Plantino alabó la enseñanza jesuítica al prologar un Marcial expurgado por la Compañía (M. Bataillon, Erasmo y España, México-Buenos Aires, 1966, p. 772). 
pero también los epigramatistas: en primer lugar Marcial "purgado", después los Emblemas de Alciato y Flores poetarum ${ }^{189}$.

A su vez, la Antología Griega fue utilizada y extractada para la escuela desde el Compendium Grammaticae Graecae de Jacobus Ceporinus (Basilea, 1522) ${ }^{190}$. Ni que decir tiene que la Compañía adaptó asimismo a sus fines pedagógicos la Antología Planudea (Selecta epigrammata Graeca) en 1608. El cardenal Quirini, un alumno de los jesuitas en Brescia (c. 1695), confesó que la Antología había hecho las delicias de su juventud ${ }^{191}$.

Jesuitas fueron los máximos admiradores de Marcial en el s. XVII. A la pluma del aragonés Baltasar Gracián se debe el vademécum de la Agudeza y arte de ingenio, libro que, prafraseando al propio Gracián, podría decirse que no es un almacén farragoso de la agudeza, pues el autor la "ministra saçonada, dispuesta y aplicada"192. El tratado es en realidad un canto al epigrama en todas sus modalidades. Ya la propia división de la agudeza en agudeza de artificio menor o "incomplexa" y agudeza de artificio menor o "compuesta" revela el influjo de la teoría epigramática, dado que el epigrama, según Escalígero, se dividía en epigrama simple y compuesto: como se ve, se sigue la misma estructura metodológica, aunque se la dote de un significado diferente. En esta búsqueda de conceptos y agudezas, no es de extrañar que Marcial obtenga el primer puesto entre todos los poetas citados por Gracián, que rindió al padre del epigrama latino un calurosísimo elogio: "Tributó nuestra Bílbilis a la gran emperatriz del mundo no monstruos, como el África, sino aquel que lo fue en el ingenio. Entró Marcial en Roma, destinado a la oratoria; mas su estremada prontitud, no sufriendo pigüelas de encadenada eloquencia, se remontó libre en todo género y modos de agudeza, quantos se eterniçan en sus Epigramas. Quedó vinculado este gusto (que no le llamo absolutamente acierto) en esta ingeniosa provincia, hermosa cara del orbe; y nunca más valido que en este feraz siglo, en que han florecido sus ingenios con su dilatada

${ }^{189}$ J. García Icazbalceta, Bibliografía mexicana, p. 297.

190 James Hutton, The Greek Anthology in France and in the Latin Writers of the Netherlands to the Year 1800, Cornell Studies in Classical Philology, XXVIII, Ithaca, Nueva York, 1946, p. 15.

191 James Hutton, The Greek Anthology in Italy to the Year 1800, Cornell Studies in English XXIII, Ithaca Nueva York 1935, p. 39, 42.

${ }_{192}$ Agudeza y arte de ingenio, Discurso LVIII, p. 313. 
monarquía, discurriendo todos a lo libre, assí en lo sacro como en lo profano $^{\prime \prime 193}$.

A través mayormente de la Compañía aprendieron los españoles a hacer poemas en latín y a teorizar sobre la poesía. En efecto, la definición de epigrama que dio el maestro Pedro González de Sepúlveda al licenciado Cascales ${ }^{194}$ está tomada al pie de la letra de las Institutiones poeticae del jesuita Jacobo Pontano (Spanmüller) ${ }^{195}$; pero Sepúlveda, que reconoció honradamente su deuda, no se dio cuenta de que Pontano a su vez había copiado literalmente tal definición de la Poetice de Julio César Escalígero ${ }^{196}$ y de que ésa era la razón de que estuviese impresa en cursivas en el tratado del ignaciano. Al final, como se ve, la Compañía acabó por deglutir todo, incluso la doctrina de sus más acérrimos enemigos religiosos. En buena parte, la educación primaria y secundaria había quedado en sus manos.

No a todos satisfizo esta inclusión de Marcial en la escuela. Un humanista tan cosmpolita como Benito Arias Montano, al crear en 1597 una cátedra de Latinidad en Aracena, dispuso expresamente que se pudieran "leer en público todos los poetas latinos, exçetando Marcial, que no es para leer en público, sino en particular a presonas discretas"197. Hemos visto cómo Arias gustó del epigrama en sus composiciones juveniles. Esta cláusula, por consiguiente, no implica ningún rechazo del género; sí revela, en cambio, que las ideas que tenía Montano sobre la enseñanza y la formación del niño discrepaban o, mejor dicho, se enfrentaban con la pedagogía de la Compañía, más abierta e innovadora. $\mathrm{Y}$ en este punto bueno será recordar que la exclusión de Marcial como autor escolar contaba con la aprobación de Álvar Gómez de Castro, cuya autoridad pudo haber influido también, de manera inconsciente, sobre el

${ }^{193}$ Agudeza y arte de ingenio, Discurso LI, p. 274.

194 En las Cartas filológicas de Francisco Cascales (ed. J. García Soriano, Madrid, 1954, III, p. 218).

195 Utilizo la segunda edición: Jacobi Pontani de Societate Iesu Poeticarum Institutionum libri III. Editio secuda emendatior, Ingolstadii, 1597. La definición se encuentra en el capítulo III del libro III.

196 Utilizo la edición Julii Caesaris Scaligeri viri clarissimi Poetices libri septem, apud Petrum Sanctandreanum, 1594, III 126, p. 430.

197 Cf. J. Gil, Arias Montano en su entorno. Bienes y herederos, Badajoz, 1998, p. 301. 
anatema de nuestro biblista. Mas el desacuerdo de Montano con los jesuitas no se redujo a esta cuestión, sino que se extendió a otras materias, señal de que hubo un desencuentro profundo entre unos hombres cuya mentalidad, en el fondo, no divergía tanto ni por sus intereses (la pureza de la fe) ni por sus soluciones a los problemas (la atención preferente a la escuela).

\section{Autoría de una enmienda alabada y controvertida}

En el Colegio de los Españoles de Bolonia se formó el más ilustre de los humanistas del reino de Aragón: Antonio Agustín (1517-15868), el gran anticuario. Es fama que Agustín (1517-1586) hizo una conjetura al texto de Marcial digna de ser tenida en cuenta. En el famoso poema dirigido a Liciniano (I 49, 3-4) se lee:

Videbis altam, Liciniane, Bilbilin,

Equis et armis nobilem.

Ahora bien, en la Antigüedad Bílbilis no era famosa por sus corceles, sino por sus aguas, que procuraban al hierro de las armas un temple especial (IV 55, 15). De ahí, pues, la corrección de equis en aquis, conjetura que aceptó sin reservas Juan Luis de la Cerda; alabando sobremanera "egregiam operam Antonii Augustini in corrigendo uersiculo Martialis" (II, p. 543 a). Sin embargo, en un manuscrito autógrafo conservado en El Escorial el propio Agustín ${ }^{198}$ atribuyó la paternidad de la enmienda a Joannes Paccius, es decir, a Juan Páez de Castro, el malogrado humanista de Guadalajara; a él, pues, ha de ser restituida. Después se apropió de la conjetura Ramírez de Prado ("legendum omnino aquis, cùm quòd Bilbilitanorum equorum nulla usquam mentio, tum quòd Salonis aquae ferro ad cudenda arma nobilissimae" [p. 84 de su edición]) y bajo la autoridad de Ramírez de Prado la admitieron en el texto los profesores parisinos que prepararon el Marcial de la colección Lemaire (I, p. 92). Curiosamente, el jesuita Rader adjudicó la autoría a Zurita en su segunda edición de Marcial ("Hieronymus Surita rectè castigat" [p. 124]), sin duda despistado por la mención que había hecho Ramírez de Prado al gran historiador aragonés.

${ }^{198}$ Alveolus, edición de C. Flores Selles, Madrid, 1982, p. 101. 


\section{El Brocense (1523-1601). Un gramático ante Marcial}

En su Minerva Francisco Sánchez utilizó en prueba de sus asertos no pocos versos tomados de los epigramas de Marcial. Pondré aquí un ejemplo para dar idea de la profundidad de su pensamiento y, al mismo tiempo, de la extrema rigidez con que aplicaba sistemáticamente sus principios $^{199}$. Para el Brocense no existe en latín el dativo agente ${ }^{200}$. Al pasar revista y refutar los ejemplos de dicha construcción aducidos por los demás preceptistas ${ }^{201}$, toca dos casos de Marcial: Si cui forte legeris (II 1, 6; "si ab aliquo", había comentado Calderini) y totus tibi triduo legatur (II 6, 12). En ambos, arguye el Brocense, el dativo no puede ser agente, porque los romanos no leían, sino que se hacían leer los libros por el anagnostes: luego ni cui ni tibi son agentes. En un tercer ejemplo, At non stamina differt Atropos atque omni scribitur hora tibi (X 44,6), el dativo es un datiuus acquisitionis. La teoría, expuesta con solemnidad oracular, a la manera de otro gran gramático, Lachmann, es más brillante que verdadera, si bien acierta plenamente en el tercer ejemplo, donde tibi no es agente ("every hour is written down to your account", traduce Shackleton Bailey, "chaque heure est portée par elle à ton compte" Yzaac); y aun en II 1, 6 Shackleton Bailey parece dar la razón al Brocense: "if you happen to get read to somebody". El resto de las observaciones hechas en la Minerva no tiene tanto interés. De todas maneras, merece la pena destacar los ejemplos de acusativo interno tomados del poeta, para probar en este caso la inexistencia de la voz media 202 : garrire (I 89, 1-2 [p. 274]), natare (XIV 196, 2 [p. 290]), redolere (XIV 59, 2 [p. ]), plaudere (XII 50, 5 [p. 302]), ventilare (III 82, 10 [p. 324]). En IV 1, cuando ordenó por decreto que el genitivo partitivo dependiente de un superlativo fuese considerado como una elipsis de ex numero, citó el Brocense en las últimas ediciones de su obra (p. 448) un verso de Marcial (VI 4, 1) Censor

199 P.e., al padre Juan Luis de la Cerda le indignó que el Brocense (Minerva, IV De ellipsi, p. 444 Salor-Chaparro) sentenciara que, en el caso de verbos como curro, ambulo, sedeo, etc., no se ponía el acusativo cursum, ambulationem, sessionem para evitar el pleonasmo, y adujo numerosos testimonios del griego para probar lo contrario (en su comentario a Aen. XII 680 III, pp. 749-50).

${ }^{200}$ Cf. Minerua, II 4 (p. 138ss. Sánchez Salor-Chaparro).

${ }^{201}$ Minerua, III 4 (p. 330 Sánchez Salor-Chaparro).

${ }^{202}$ Minerua, III 3 (p. 242 Sánchez Salor-Chaparro). 
maxime principumque princeps, sin percatarse de que maxime sólo concertaba con censor y no con princeps, equivalente en este caso a $\mathrm{B} \alpha \sigma \iota \lambda \in \mathrm{u} s \quad \beta \alpha \sigma \iota \lambda \epsilon \in \omega v$, el título persa hsayaziya hsayaziyanam; es probable que Sánchez se haya confundido con Hor. Od. IV 14, 6, donde sí aparece maxime principum. Otro caso de interpretación errónea -y todavía más forzada- tendremos ocasión de ver más adelante. Preciso es reconocer que los comentarios del Brocense no brillan a la altura de sus obras lingüísticas: como les ocurre a otros grandes teóricos de la lengua, el Brocense es mejor gramático que filólogo.

La poesía del gramático se mueve dentro de los cánones de la Antología Palatina (así, p.e., en el gusto por los enigmas, cf. XLIXss.), de la que hizo varias traducciones (CXXVIII-CLIX), y preludia ya el barroco con sus manierismos (cf. XLV, LIV, LX 144ss.), que suponen una cierta vuelta a los juegos formales de la Edad Media. Ello no quiere decir ni mucho menos que Marcial esté ausente de sus composiciones. Una imitación clarísima de Spect. V 2 (uidimus, accepit fabula prisca fidem) es XX 42 nec sinit, accipiat fabula prisca fidem,"y no me deja (escribir); dése crédito a la vieja fábula"203; y en la retorcida sintaxis de XXV 7-8 sed isto Tempore qui est firmus, discere, crede, satis no resulta difícil hallar un eco de X 62, 12 Aestate pueri si ualent, satis discunt.

\section{La edición parcial de Lorenzo Ramírez de Prado (1583-1658)}

En 1607 apareció en París, y por partida doble ("apud Michaelem Sonnium ${ }^{204 "}$ y "apud Claudium Morellum"), la más importante aportación que haya hecho jamás un español a la crítica de Marcial: los

203 Así debe traducirse, y no "ella hace que no demos crédito a las viejas leyendas" (A. Carrera de la Red). En otras ocasiones la puntuación traiciona a la editora: así en XLI 10 "pendet araneola pulchra puella prius" 'cuelga de una telaraña' (no "araneola,") o en LX 35 "Sub jugo iam misi Seras, frenauimus Indos" (no "misi, seras")

${ }^{204}$ Por error se imprime "Sommum" en B. J. Gallardo, Ensayo de una biblioteca española de libros raros y curiosos, editada por M. R. Zarco del Valle y J. Sánchez Rayón, Madrid, 1889 (reimpr. Madrid, 1968), IV c. 33, y "Sommum" se lee en J. de Entrambasaguas, Una familia de ingenios, p. 105. Los tres ejemplares que he consultado en Sevilla salieron de la imprenta de Sonnius; la portada de Morellus la vio Entrambasaguas en la Biblioteca Nacional de Madrid. 
Hypomnemata de D. Lorenzo Ramírez de Prado, hijo del licenciado D. Alonso Ramírez de Prado, del Consejo Real y de la Real Hacienda, y de $\mathrm{D}^{\mathrm{a}}$ María Velázquez. Un año antes, en 1606, el padre de nuestro comentarista, D. Alonso, había entrado en la cárcel, acusado de un gravísimo desfalco (el famoso y turbio asunto del Desempeño regio), que le valió ser condenado el 25 de setiembre de 1608, después de muerto, al pago de la friolera de 340.000 ducados. La caída en desgracia de D. Alonso y su fallecimiento poco antes de promulgada la sentencia (15 de julio de 1608) no afectaron, sin embargo, a la carrera de su brillante hijo, un hombre singular que destacó tanto por su afición a las letras como por su dedicación a la abogacía y a la política. Si ya fue toda una admonición que lo apadrinara en el bautismo el famoso humanista Pedro de Valencia, de mayor le dedicaron rendidas alabanzas Cervantes, Lope de Vega, Jáuregui, Esteban Manuel de Villegas y Francisco Cascales. D. Lorenzo, además de ser un coleccionista de primera categoría ${ }^{205}$, escaló todos los honores del reino, a pesar del escándalo paterno y de las habladurías que lo incriminaban, tal vez fundadamente, de tener lejana sangre conversa en las venas: fue familiar del Santo Oficio (1616), embajador en Francia (1628) y caballero de Santiago (1631) y se sentó en los Consejos de Nápoles (1617), de Indias (1626), de Castilla (1642) y de Hacienda ${ }^{206}$. Mas volvamos a nuestro Marcial y a los Hypomnemata, que abarcan sólo Los espectáculos y los cuatro primeros libros de los epigramas.

El joven abogado, suelto de lengua, criticó con cierta acidez la obra del jesuita Mateo Rader (¿1561?-1634), un comentario macizo, muy al estilo tudesco, lleno de erudición pero indigesta a veces y carente de chispa, que había aparecido en Ingolstadt en 1602. Además de tildar de innecesarias las conjeturas del alemán (Spect. I 3 [p. 6]: la enmienda Iones [por honores, defendido por Calderini y Mérula], en realidad de Escalígero, es aceptada por Lindsay; 21, 5 [p. 19]: pecori [por pecudum],

${ }^{205}$ En la edición de Oriencio (Salamanca, 1604) firmó D. Lorenzo el prólogo

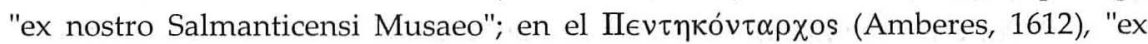
Musaeo nostro Madridiensi".

206 D. Lorenzo merece por sus propios méritos una biografía pormenorizada, tarea que por fuerza tiene que hacer un filólogo clásico. Véase mientras tanto el estudio de J. de Entrambasaguas, Una familia de ingenios. Los Ramírez de Prado, Madrid, 1943, de donde extraigo algunas de estas noticias. 
lectura de códices aceptada por Lindsay), Ramírez de Prado se permitió hacer varias burlas sobre su antecesor: "argutatur Raderus" (I 25, 7 [p. 59]); "egregiè hîc sese ridendum propinauit Raderus" (I 66, 5 [p. 100]); "in hoc errore Raderus toto errat coelo" (II 8, 3 [p. 152]); "errat more suo Raderus" (II 16, 3 [p. 158]); la nota a macte está sacada "ex meris lexicis" (IV 13, 2 [p. 307]); el religioso hace honor a su nombre ("radens Raderus"), al barrer, es decir, tomar toda su doctrina de Mercurialis y Faber (IV 19 [p. 313] ${ }^{207}$. El alemán había expulsado de su edición el epigrama dedicado a Leandro (Spect. 25), expulsión que a Ramírez le pareció con razón excesiva y que juzgó con dureza: "Leandrum hunc ad amicam euntem ita execratus est Raderus religiosus sacerdos ut à suo codice et commentario libro miserum iuuenem amandarit... Ego verò pati non possum superciliosos istos Censores qui nequitias Martialis nobis adimunt, sibi relinquunt. Satius fuisset, sanctissime vir", le increpa, "ut totum Martialem intactum reliquisses, ne scilicet purissimae manus deligendis epigrammatibus et interpretandis inquinarentur... Interim secede, Cato tertius è caelo lapsus"' (p. 24) ${ }^{208}$.

No se había secado aún la tinta del papel cuando los Hypomnemata recibieron un tremendo varapalo. Un "novel" latinista, Claudio Musambert d'Abbeville ${ }^{209}$, les dedicó una crítica despiadada que hizo imprimir por Dionisio Langlois en ese mismo año de 1607: un prodigio de velocidad, tanto de la pluma como de los tórculos. Hoy se acepta unánimemente que bajo el pseudónimo de Musambert se encubría el humanista Teodoro Marcile o Marcilius (1548-1617), que había publicado a su vez un comentario a los 29 primeros epigramas de los Espectáculos ${ }^{210}$.

${ }^{207}$ Pero no siempre la crítica es adversa; en IV 88, 8 anota: "acute Raderus" (p. 370).

208 Un comentador (¿el propietario Juan Caravallo y Vera?) anotó al margen de este pasaje en uno de los dos ejemplares conservados hoy en la Biblioteca Capitular de Sevilla (57-6-13): "dignus legendi locus adversus mentitos Catones" (p. 24).

209 In Laurentii Ramiresii ad M. Valerium Martialem hypomnemata commonitoria, quae et plurimis poëtae locis obscuris lucem dant et Ramiresii errorum euerricula sunt, París, 1607. Da algún ejemplo de la crítica destemplada de Musambert B. J. Gallardo, Ensayo, IV, c. 33-34.

210 Cf. D. M. Robathan-F. Edward Cranz, "Persius", en el Catalogus translationum et commentariorum, III (Washington, 1976), p. 302); Frank-Rutger 
Aunque ya era un hombre talludo, "Musambert" alardeó en ese librito de tener pocos años, al igual que $\mathrm{D}$. Lorenzo, quizá porque su propio comentario lo había compuesto "adolescentiae limine ipso". De esta suerte la polémica subió de tono, haciéndose más descarada y agresiva. Arrogándose importancia, y de verdad la tenía, como profesor regio de Latín, el holandés afincado en París se revistió de un tono doctoral, como si su pretensión no fuera otra que amonestar al español. Había múltiples motivos para publicar la censura, aunque el libro por su futilidad no lo mereciese: como manifestó retóricamente "Musambert" al senador Le Vois, a quien puso por juez de su duelo literario contra D. Lorenzo, la crítica de la obra de Ramírez no era sino la defensa de Cujas, de Scaliger, de Justo Lipsio; la defensa de la tierna edad de la juventud contra las salaces procacidades del español; la defensa de toda la república cristiana contra todas los palabras malsonantes, dignas de ser expulsadas del comercio humano, y la defensa, por fin, también del propio Ramírez, pues quien aconseja, ayuda: "Moneo ego Ramiresium amantissimè, temperet deinceps in coeno spurcarum interpretationum volutari velle et quasi Suburram struere doctrinaeque principes insectari parcat". Tras la dedicatoria vienen los epigramas, repletos de insultos, en los que Ramírez se convierte en "corneja" y "grajo ridículo"; a juicio del propio "Musambert", habría de ser llamado no "Ramiresius", sino "Rabiresius" (p. 2).

La acusación más repetida es la de soberbia e ignorancia. Presa fácil para "Musambert" fueron los errores latinos del español: "adfirmarem" por "adfirmem" o "adfirmarim" (p. 14), "vulgariter" por "vulgo" (p. 78), "suboleo" por "subolet mihi" (p. 89), "pigrissimus" en vez de "pigerrimus" (p. 145). Si el latín de Ramírez era malo, peor todavía era su griego: "Graeca aut non habuisti aut nescisti" (p. 9); "Inscitia hellenismi fecit ut obscurus sermo ille videretur, cum vir nubit in foeminam: dictum Atticè pro cùm vir nubit tamquam foemina" (p. 37). "Musambert" fue pasando revista al comentario de Ramírez epigrama por epigrama, deteniéndose con mas pormenor en los dos primeros libros. Su erudición, no exenta de cierta fatuidad, hace gala de un estilo rebuscado en el que abundan las palabras raras y las expresiones metafóricas: así,

Hausmann, "Martialis, Marcus Valerius", en el Catalogus translationum et commentariorum, IV, p. 281. 
las palabras de Ramírez se transforman en ruidos de animales: "crocitationes in Raderum" (p. 15), "hirrire" (p. 17). Otro ejemplo de extravagancias léxicas: "Credo ego te arbitrari omnes hoc saeculo qui ubique gentium mortales blennos, bliteos esse, Saturnias lemas lippire" (p. 13; el latín sólo se comprende a la luz del proverbial кодокúv $\theta \alpha$ เs $\lambda \eta \mu \hat{\alpha} v)$. Cierra el folleto el siguiente epigrama, dedicado a Ramiresio Martialis interpreti:

Felix Iberus et tua potens manu,

Qui Martialem sic potes neci dare.

Quis iam triumphos et coronas aureas

Victoriis neget tuis? Tibi principes

Doctrinae et ingeni, Iosephus Scaliger,

Et Lipsius, Casaubonusque supplices:

Tibi doctor ille rasor impolitiae

Raderus, omni liberans vatem stupro.

Capitalis et disertus est unus modo

Ramiresius. Nam Martialem perdere

Solus poëtam glossulis nouit suis.

Sed Claudius venit Aesculapij vicem

Orcique vatem deripit peculio.

¿Qué es lo que había molestado a Marcilio? Sin duda ninguna, el estilo deslenguado de Ramírez de Prado. En la primera página de los Hypomnemata ya sale a relucir "Theodorus Marcilius vir suo iudicio apprimè doctus, qui in haec epigrammata spectaculorum longas farragines congessit, et si Diis placet cocum Martialem nominauit, sequutus Robertum Titium", y más adelante se lo acusa de ignorante (p. 3). Después se templa el tono ("Benè Marcilius... dicit" [p. 6]; "Marcilij emendatio fortè arridebit" [p. 17]; "rectè hoc loco Marcilius" [p. 19]; "rectè Marcilius notauit" [p. 24]), pero su insolente comienzo había herido en lo más profundo el orgullo profesoral. El holandés, cegado por el apasionamiento, no siempre estuvo acertado en sus juicios, aunque le asistiese la razón al pedir a Ramírez menos soberbia y más moderación en su pluma: un consejo que bien pudiera haberse aplicado a sí mismo.

El joven D. Lorenzo había salido escaldado de su primer encuentro con el extrnajero, pero lo peor aún estaba por llegar. En efecto, también Rader le devolvió las lindezas en la segunda edición de su obra, publicada de nuevo en Ingolstadt en 1611: era Ramírez, y no Rader, quien 
merecía el apelativo de "radens", pues el español le había copiado a él muchas cosas (p. 310); no en vano "Musambert" (p. 156) había calificado el comentario de Ramírez como "euerriculum Raderi et alienarum lucubrationum" ("escoba de Rader y de interpretaciones ajenas"). Hay que reconocer que algunos de los palmetazos propinados por Rader estaban bien merecidos. En III 10, 1-2 Ramírez de Prado había dado a milia bina menstrua una interpretación imposible que, curiosamente, había rechazado él mismo a continuación: "Si illud millia bina sestertia sint, efficitur summa duorum computorum nostrorum" (p. 226). Le objetó con razón Rader: "Frustra hîc Ramiresius vagatur de sestertio neutrius g. cum et ratio grammatica loquendi formam neget et res ipsa loquatur" (p. 251). El jesuita no se percató, en cambio, del error más grave que había cometido su criticado émulo: que "dos millones" o "dos cuentos" (latinizados por Ramírez en un macarrónico "cumputi") no se dice en latín bina milia, sino uicies (centena milia), expresión que en I 100, 1 (p. 128) el español reduce erróneamente a "veinte quentos de maravedís". En III 36, 10 se pasó de listo Ramírez (p. 242, cf. p. 181) al suponer que el chiste se encierra en la ambigüedad de la palabra rudem: el bastón dado a los gladiadores jubilados y la toga rudis ("crasso et impolito filo contexta") por oposición a pexa (cf. II 44, 1; VII 88, 8 [pero se habla aquí de rudes lacernae]; pexatus en II 58, 1). Nuevo y justificado rapapolvo de Rader: "Rudis gladiatoria certa est, toga incerta, immo nulla, nusquam enim reperitur rudis absolutè pro toga" (p. 167). Otro tirón de orejas: en IV 6, 3ss. al "frigida est haec refutatio" de Ramírez (p. 300) contesta Rader: "Tua vero ratio lepida: formosus fuit Arginus, ergo non improbus. $\mathrm{O}$ nouum dialectici acumen! Facilius et probabilius contrarium inde conclusisses" (p. 301). El jesuita no se ensañó en sus críticas filológicas, pues en alguna ocasión aprobó la propuesta de su rival: así en III 44, 15 "Alioqui non displicet Ramiresii et aliorum ad coenam venio, fugas edentem" (p. 273) ${ }^{211}$ o en IV 55, 29 "Non absurdè Ramiresius videtur sentire etiam in Italia reperiri barbara oppida quae possint rideri ut Bituntum" (p. 334).

Por el contrario, en el nuevo prólogo Rader se pasó de la raya en sus censuras al español, tratándolo sin ecuanimidad alguna y acumulando un insulto tras otro: Ramírez de Prado se transforma en un "Sotadicus

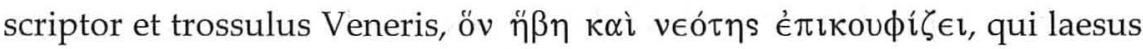

211 "Hanc lectionem cum Ramiresio adoptavimus" (Prof. Par. [I, p. 303]). Sedentem, en cambio, Lindsay. 
à me nunquam, in me tamen veluti cornutus Satyrus incurrit"; en definitiva, en un pagano más que en un cristiano. Las explicaciones un tanto lúbricas de D. Lorenzo son condenadas con una apóstrofe insultante ad hominem: "i modo, nepotule Cupidinis, lege et lambe et linge omnia Martialis phlegmata, analecta et oleta à me reiecta, non inuideo: vomicas omnes et gangraenas et phagedaenas refrica, ficos et mariscas, fungos, rhagadia, condylomata collige, serua". El español no hubiese debido comentar con desvergüenza tabernaria el epigrama de Pasífae (Spect. 5): más le hubiese valido imitar a Marcilio y no a Calderini, sin hacer demasiado explícita en sus comentarios las alusiones obscenas. Rader no se había reservado para disfrute personal las verdulerías del poeta, como le había dicho en chanza grosera Ramírez, sino que tuvo que leer enteros los Epigramas para separar las gemas del estiercol; al estar dirigido su comentario a la escuela pública y al uso de la juventud "pro ratione instituti Societatis nostrae", convino quitar de él todo el cieno y el fango, a fin de ofrecer una obra limpia y pura a niños y adolescentes. ¿Qué valían las críticas del español ante los elogios de Martín del Río, Jacobo Gretser, Justo Lipsio y José Justo Escalígero? D. Lorenzo era un aprendiz de latinista que tendría que ser devuelto a Orbilio: así lo demostraban algunas "perlas" sacadas a relucir convenientemente por el jesuita; sin embargo, ese humanista tan bisoño e inexperto se deshacía en "insolentissimis... ampullationibus, thrasonicis iactationibus, ventosa lingua, impurissimo ore". La diatriba terminaba con una amenaza: un libro como los Hypomnemata merecería que se crease un tribunal censorio que castigase a los escritores obscenos y corruptores de la juventud, de la misma manera que el Oficio de la Inquisición actuaba contra los herejes velando por la fe; tal vez por esa razón, temiendo la censura, el español había enviado a imprimir su libro a París. Último trallazo: Rader no le cubría de más críticas por impedírselo sus compañeros de Orden.

Esta injusta y acerba acusación de inmoralidad escoció en el alma a nuestro Ramírez de Prado, que ni corto ni perezoso escribió a toda prisa una réplica de veinte páginas que entregó en 1612 para su publicación al impresor madrileño Alonso Martín de Balboa. Estaba ya compuesto el folleto en los tórculos y listo para su encuadernación cuando alguien, no sabemos quién ${ }^{212}$, dio el chivatazo a la justicia: el librito carecía de las

212 Parece que tiró de la manta el padre Cristóbal López, de la Compañía de Jesús (Proceso, f. 30v). 
debidas licencias. La denuncia paró la distribución de los ejemplares y se pidió para el impresor, preso con toda su plantilla ${ }^{213}$ en la Cárcel real de Madrid, una pena de 500 ducados y seis años de galeras y para el autor ocho años de destierro y una multa de 2.000 ducados. D. Lorenzo, en arresto domiciliario ${ }^{214}$, se revolvió ardorosamente contra las acusaciones.

213 Se componía ésta de García Martínez, corrector, Mauricio Bolineo, tirador, Juan Fox, tirador, y Gaspar García y Domingo García, componedores de letras. Alonso Martín acusó a Mauricio Bolineo, a Gaspar García y a otro componedor, Andrés Quirinos, sus compañeros de prisión, de ser enemigos capitales suyos y de querer perderlo por ello (Proceso, f. 112r).

214 "Estoy presso en mi posada con dos guardias", escribió cuando pidió libertad bajo fianza, alegando ser regidor y procurador de Cortes por Salamanca (Proceso, f. 77r). El alcalde Francisco Márquez de Gaceta le negó la petición (Proceso, f. 80r). Declararon en el proceso a favor de D. Lorenzo, testificando que era "hombre docto y muy inteligente, de letras buenas" fray Domingo de los Reyes, dominico (f. 169r), fray Rafael Díaz, consultor del Santo Oficio (f. 171r), fray Alonso Loarte, carmelita (f. 173r; al margen se anota: "famoso varón"), el doctor Francisco Sánchez de Villanueva, presbítero, predicador en la Corte (f. $174 \mathrm{v}$ ), el licenciado D. Vicente Noguera, oidor en la Chancillería de Oporto (f. 176r), Juan Bautista Lavaña, caballero de la Orden de Cristo y cosmógrafo mayor del rey (f. 178r), D. Juan Batheo, entretenido del rey (f. 179r), fray Diego de Ortigosa, trinitario (f. 180v), fray Hortensio Pallavicino, trinitario (f. 182r), fray Francisco de Jesús, trinitario (f. 183v), Luis Cabrera de Córdoba, criado del rey (f. 184v), fray Gregorio de Pedrosa, jerónimo, predicador del rey (f. 186v), D. Antonio de Torre y Sedano, regidor y procurador de Toro (f. 188v), Martín Pérez de Escorza, abogado (f. 189v), el licenciado D. Francisco de Alarcón, colegial del Colegio Mayor de Salamanca (f. 190v), D. Fernando Carrillo Chumacero, catedrático de Decretales en el Colegio Mayor del Arzobispo (f. 193r), D. Pedro de Torres Rámila (f. 195v), Mateo de Villanueva y Ovando (f. 197r), el doctor Juan Alonso de Valverde, presbítero, predicador en la Corte (f. 198r), el licenciado Pedro de la Lastra Zorrilla, abogado en la Corte (f. 200r), D. Diego de Montoya Castellón, abogado (f. 201r), el licenciado Pedro Arnalte, abogado (f. 202r), D. Antonio Ronquillo, colegial del Colegio Mayor de San Salvador de Oviedo de Salamanca (f. 203r), el licenciado D. Baltasar Navarro de Arroitia (f. 204v), fray Cristóbal de Fonseca, agustino (f. 206r). Una lista en verdad impresionante de nombres principales, en la que sólo faltan por razones obvias los jesuitas. Fray Hortensio Paravicino (el predicador de moda retratado por el Greco, a quien Ramírez de Prado llamó "Academiae Salmanticensis sydus" 
El comentario de los Epigramas lo había empezado de mozo en Salamanca cuando estudiaba Leyes, "llevado de la afición de ser [Marcial] poeta español"; alguien había llevado su original a París, donde había corrido de molde contra su voluntad; esta publicación había motivado que Mateo Rader sacase a la luz su segunda edición, criticándolo; el único propósito que había perseguido D. Lorenzo al componer el nuevo folleto no era otro que probar su sana intención al redactar sus Hypomnemata y responder a las observaciones de Rader "en defensa de" su "crédito y honra"215. Veamos ya en qué consistió la réplica al jesuita, impresa pero nunca divulgada.

La obrita de veinte folios se abre con una carta del tipógrafo anónimo- al lector. Cuando deambulaba por la calle de Atocha ${ }^{216}$, nos cuenta, un amigo -encubierto bajo las siglas Alpha.B.M.- se sacó de la faltriquera unos papeles y se los entregó gozoso: no era otra cosa que la defensa de D. Lorenzo. Llegado a su casa, el impresor la leyó ansiosamente y tanto le gustó que la imprimió sin consentimiento del autor ("inscio Autore reliquisque Amicis"). Estos rodeos y circunloquios indican hasta qué punto Alonso Martín y D. Lorenzo habían extremado la prudencia: como la Compañía era poderosísima y su enfado temible, lo mejor era dejar las cosas ocultas lo más posible en un discreto anonimato.

D. Lorenzo encabezó su carta nuncupatoria, escrita el 1 de mayo de 1612, a D. Diego de Silva, caballero de Alcántara, comendador de Herrera y duque de Francavilla, el mismo noble -hijo del famoso Ruy Gómez de Silva- a quien Juan Luis de la Cerda dedicó su comentario a la Eneida: D. Diego, como buen defensor de la Compañía, podría apreciar la justicia de su defensa contra las injurias de Rader, que había sobrepasado todos los límites de contención y de urbanidad exigibles a un jesuita. Después de los atentos prolegómenos, la diplomacia hace mutis y comienza un ataque despiadado. Al denigrar al español Rader se ha quitado la máscara: no es más que un Trasón (el soldado fanfarrón del Eunuco de Terencio) que, en su afán por embestir, se ha lanzado contra Ramírez "como un sátiro cornudo" (las palabras entrecomilladas están tomadas

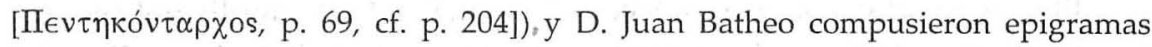

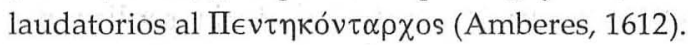

${ }^{215}$ Todo el proceso se encuentra en A.H.N., Consejos, leg. 30.197 nº 3.

216 "Ibam fortè viâ Atochae, sicut meus est mos, Nescio quid meditans librorum, totus in illis", dice en imitación de Horacio, Serm. I, 91-2. 
del propio Rader). Pero Ramírez le tiene preparado un buen escarmiento, pues cual un nuevo Arquíloco le va a hacer tragarse sus palabras. Rader ha olvidado su deber de sacerdote y de jesuita al consagrarse a Marcial y reprender al español públicamente en vez de amonestarlo por una carta privada. No es propio de un religioso criticar al modo rastrero de la comedia antigua. Rader celebra misa todos los días; pero ¿cómo pueden elevar la hostia a Dios unas manos que no paran de manosear a Marcial, poeta obscenísimo? En vez de dedicarse a explicar sus epigramas, y encima sin fruto, el alemán debería de haber puesto todo su empeño en escudriñar la Teología y las Sagradas Escrituras o, si no, en estudiar a los filósofos, a los épicos o a los trágicos, como sus compañeros de Orden Martín del Río o Juan Luis de la Cerda. Los jesuitas, sí, deben enseñar poesía para que los niños aprendan la lengua latina, pero Rader se hace reo de lascivia al leer la comedia y la poesía erótica y alabar los Priapea, prohibidos por la Inquisición. Rader ataca a Ramírez por haber explicado en Spect. V el mito de Pasífae; pero ese mito también lo había explicado San Jerónimo en el libro I del Contra Joviniano: ¿acaso es más santo Rader que San Jerónimo? Para reprender los vicios hay primero que exponerlos: así lo hizo San Pablo, incluso la Biblia está llena de historias obscenas, San Agustín describió las costumbres de los romanos para censurarlas y San Ignacio mártir, Arnobio y Juan de Salisbury siguieron la misma pauta; hasta el propio jesuita Sánchez trató de cosas turpísimas, pero con alabanza. Rader obró de manera contraria, al expulsar de su obra algunos epigramas por obscenos; mejor hubiera sido explicar a Marcial en su totalidad, pero poniéndose, como cristiano, en el papel que desempeñaron los satíricos en la Antigüedad pagana. El jesuita y D. Lorenzo son hombres muy diferentes. La humilde profesión de Rader es enseñar a los niños. En cambio, Ramírez está lejos de las férulas de los pedagogos: tiene otra edad, otra vida, otras ocupaciones, no busca sólo, como el maestro de niños, una elegancia de estilo huera y llena de afeites ("futilem fucatamque sermonis elegantiam"). En definitiva, cabe preguntarse con Séneca: ¿qué aprovecha el gramático -esto es, Rader- a la virtud?

Bien se ve que, cuando intervino la justicia, el intríngulis del asunto no era tanto la falta de licencias cuanto la acerbidad de la réplica de Ramírez de Prado; y es bastante más que probable que en la detención del libro fuera gran parte la propia Compañía de Jesús: el primer declarante fue el jesuita Cristóbal López. Aunque D. Lorenzo había 
regalado ejemplares de sus Hypomnemata a dos ignacianos famosos, los padres Juan Luis de la Cerda ${ }^{217}$ y Juan de Pineda ${ }^{218}$, en prueba de amistad y también de merecido reconocimiento a su magisterio, en 1612 no debió parecer de buen tono ni políticamente correcto que un jesuita como Rader, profesor por más señas del Colegio ignaciano en una Alemania dividida por la religión, recibiese los cintarazos de un Aristarco católico y encima español. La sensatez o, por mejor decir, la razón de Estado se impuso: como no convenía levantar un avispero, esas $\delta \in U ́ \tau \epsilon \rho \alpha l$ $\phi \rho o v \tau i ́ \delta \in s$ acabaron por dormir también el sueño de los justos.

Pero queda todavía un punto oscuro en toda la trama. Corre la voz por la república literaria española que los Hypomnemata no fueron en realidad obra de Ramírez de Prado, sino del maestro Baltasar de Céspedes, yerno del Brocense y profesor de Prima de Gramática y después de Griego en Salamanca († 1615). G. Mayáns ${ }^{219}$ emitió un juicio muy duro sobre la actuación de D. Lorenzo ("par facinus admisit in Hypomnematis, quae surrupuit Balthasari de Cespedes"), añadiendo que D. Juan Interián

${ }^{217} \mathrm{Al}$ famoso jesuita se remitió también el folleto: "El padre Juan Luis de la Çerda, de la Compañía, dirá de lo que contiene este libro. Diómelo el padre Pedro de la Paz en 11 de julio 1612. Hizo este quaderno según me dijo el que me lo dio Don Lorenzo Ramírez de Prado. Olmedo". En cuanto al padre Juan de Pineda, lo

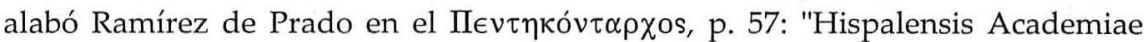
decus".

218 Según D. Lorenzo, de los pocos volúmenes que había recibido había dado asimismo ejemplares a Gil Ramírez de Arellano, a Melchor de Molina y a Juan Bautista Lavanha; es muy curiosa la afición a Marcial del cosmógrafo mayor,

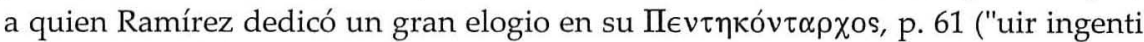
nobilitate, nobili ingenuitate uaria rerum cognitione et litterarum omnium splendore ornatus ac illustris").

${ }^{219}$ Queda recogida su opinión en B. J. Gallardo, Ensayo, IV, c. 32-33. En sus cartas sólo hallo esta breve sentencia: "Ramírez sobre Marcial es despreciable" (carta de Mayáns a Nebot del 30 de abril de 1740 en M. Peset, Mayáns y Nebot (1735-1742). Un jurista teórico y un práctico, Valencia, 1975, no 43, p. 88). En una carta de F. Velasco a Mayáns, del 15 de mayo de 1762, se habla "del plagio consabido de Dn. Lorenzo Ramírez de Prado"; pero por el contexto se deduce que

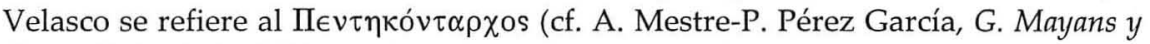
Siscar. Epistolario. XVI. Mayáns y los altos cuadros de la magistratura y administración borbónica, 3. Fernando José de Velasco Ceballos (1753-1781), Valencia, 1988, nº 213, p. 203). 
de Ayala había oído cantar unas cancioncillas satíricas sobre el famoso hurto. La verdad es que, como ha señalado G. de Andrés ${ }^{220}$, Ramírez de Prado hizo un gran elogio de Céspedes en los Hypomnemata, añadiendo que había empezado a escribirlos bajo sus auspicios: "Sic intelligendus Quintiliani locus, quem audiui a M. Baltasaro de Cespedes, mihi multis nominibus uenerando, linguae Latinae Cathedrae summo moderatore, praeceptore meo, cuius auspiciis hoc onus meis humeris imponere sum ausus et iisdem ad maiore in dies me conferam (cuius etiam ingenitam nobilitatem, acre iudicium, summam prudentiam et rerum omnium cognitionem merito suspicio et uehementer miror" (p. 33). A este testimonio taxativo ha de unirse otro documento exhumado también por G. de Andrés, una carta de Bartolomé Morlonio al padre La Cerda escrita en 1605: "Nescio quid de Martiali ibi excudendo a Cespedes audiui uel a tuo amico D. Laurentio Ramirez de Prado". Todas estas noticias casan a la perfección con una escritura notarial, por virtud de la cual D. Lorenzo se concertó en Madrid con el mercader de libros francés Guillermo Bouchon (o Bûchon) para hacer una edición de los Hypomnemata ${ }^{221}$. Pérez Pastor fechó el protocolo el 12 de mayo de 1615, mas salta a la vista que ese 1615 no es más que errata por 1605, cuando corría el rumor, como hemos visto, de que Céspedes o Ramírez de Prado iban a publicar un nuevo comentario a Marcial. D. Lorenzo, pues, entregó a sabiendas el original al librero, aunque después lo negara en el proceso, y Bouchon cumplió con su deber al llevárselo a París en una actuación que nada tuvo de subrepticia.

Parece claro que o bien D. Lorenzo dio por suyas notas tomadas de las explicaciones orales de su maestro sobre Marcial o bien Céspedes entregó, prestó o vendió algunos apuntes suyos a su alumno aventajado. Cualquiera de las dos hipótesis es posible, pues Ramírez de Prado tenía asimismo en su biblioteca papeles de otros profesores salmantinos, y muy en particular del Brocense ${ }^{222}$, cuyo comentario a las Bucólicas, como hemos visto, conservaba también Tomás Pinhel; mas el discípulo engrosó

220 El maestro Baltasar de Céspedes y su Discurso de las letras humanas, El Escorial, 1965, p. 173.

221 Archivo de Protocolos de Madrid, Juan de Mijancas, 1607 a 12 (Pérez Pastor, Bibliografía madrileña, $2^{\circ}$ parte, p. 391).

222 Así consta por una confidencia del propio D. Lorenzo en el $\Pi \in v \tau \eta \kappa o ́ v \tau \alpha \rho \chi 0$, Amberes, 1612, p. 270 y 271: "Franciscus Sanctius Brocensis in notis secundis ad Alciati emblema .95, quas ad oram autographi scriptas habeo"). 
muy considerablemente estos papeles con variopinta doctrina y los adobó con su particular ingenio y un cierto gracejo pedantesco que delata su juventud. El estilo de la obra es unitario y sin duda alguna procede de la pluma de Ramírez de Prado, a quien corresponden expresiones sueltas y descaradas como las ya citadas o "Ianus Gruterus audaculus rabula" (Spect. XI 3 [p. 15]), "Grammaticorum deliramenta, qui in etymis semper insaniunt" (I 3, 3 [p. 36]), "Os hominis" (I 66, 5 [p. 100]: dirigido a Rader; IV 55, 29 [p. 347]; dirigido a Iacobus a Cruce), "mirum est quam andabatarum more pugnent Domitius et Merula hoc loco" (III 171 [p. 229]), la impertinente acumulación de pasajes legales (cf. las alusiones a Cujas en p. 59, 70), el encendido elogio del Brocense, su maestro en Salamanca (III 24 [p. 235]: "uir dubio procul immortalitate dignus, quem mihi contigisse magistrum in his humanioribus literis semper gloriabor")223, elogio tanto más de agradecer cuanto más cercano estaba el encarce-lamiento del gramático por la Inquisición (1600), o la alusión a la impresión en Salamanca del Oriencio de Martín del Río (p. 154, 227) 224. En varios pasajes se alude al propósito, no cumplido, de hacer un comentario completo a todo Marcial (cf. p.e. I 85, 4 [p. 210]), III 31, 6 [p. 240], IV 12 [p. 307]).

En el mundo filológico unos acogieron este parto de paternidad incierta con desdén, otros con aplauso. Queda dicho como el supuesto Claudio Musambert salió desalado en airado rechazo de Ramírez de Prado. Otros críticos, sobre todo franceses, no se mostraron tan duros con Ramírez, quizá por el orgullo patrio de haber sido París el lugar de publicación de los Hypomnemata. G. Colletet ${ }^{225}$ calificó a Ramírez de Prado como "un des meilleurs interpretes de ce Poëte fameux" y los profesores franceses que prepararon la edición de Marcial para la colección de

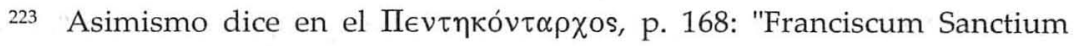
Brocensem magistrum (heu quondam meum!)".

224 S. Orientii episcopi Iliberitani commonitorium iterùm emendatum ac notis secundis illustratum, Salmanticae, ex artium taberna Arti Taberniel Antuerpiani, 1604 (un libro, según se pregona, impreso sin erratas). En efecto, antes de la edición se encuentra un proemio de D. Lorenzo al lector español, dándole dos buenas noticias: el regreso a su patria tanto de Oriencio como de Martín del Río ("cum eo magna amicitia coniunctus humanitatem summam et suauissimos eius mores amo uehementer"), que se encontraba a la sazón "apud nos in Salmanticensi Collegio".

${ }^{225}$ L'art poëtique du Sieur Colletet, París, 1658, p. 64. 
Lemaire lo citaron profusamente en sus notas, y siempre con respeto ${ }^{226}$. $Y$ si, a juicio de L. Friedländer ${ }^{227}$, el comentario de Ramírez de Prado estaba "völlig veraltet", todavía pudo espigar en él alguna cosa buena A. E. Housman 228, como la explicación de II 77, 2 (p. 206). Hoy los Hypomnemata nos ilustran en algunos pasajes obscenos, justamente lo que más repugnaba e irritaba al falso Musambert, que quería alejar a la juventud "a Ramiresii spurca lectione rerumque obscoenissimarum pictis quasi tabellis"229. Gracias a D. Lorenzo, que llama a las cosas por su nombre, se aclara el sentido de algunos epigramas muy subidos de tono, como II 33 (p. 171): "acuta nimis facetia est: alludit enim ad pondus caluum, rufum et luscum [ $=$ mentulam $]. .$. et cum fellare dici possit basiare, è conuerso, qui Philaenim basiauerit, fellare dici potest"230; III 83, 2 (p. 280): "Versus...

${ }^{226}$ M. V. Martialis epigrammata ad codices Parisinos accurate recensita, París, 1825. Señalo las alusiones en los Espectáculos y el primer libro: I p. 21 (Spect. XI 3), 26 (XVI lemma), 30 (XIX 3), 35 y 36 (XXIII 1, 2), 61 (I 10, 1), 84 y 86 (I 41, 12 y 18; en este último lugar se trata de una errata, no de una conjetura), 90 (I 46 lemma), 92 (I 49, 4), 106 (I 59 lemma), 113 (I 65, 3), 115 (I 67, 11), 133 (I 87, 6), 138 (I 91, 6), 141 (I 93, 5), 143 (I 96, 8), 146 (I 99, 9), 151 (I 104, 3), 157 (I 108, 9), 165 (I 117, 13). Curiosamente, los editores (I, p. 46) atribuyeron a Musambert un comentario que pertenece en realidad a Ramírez de Prado: la explicación de ad digitum en Spect. XXIX 5.

${ }^{227}$ M. Valerii Martialis epigrammaton libri mit erklärenden Anmerkungen von..., Leipzig, 1886, p. 125.

228 The Classical Papers of A. E. Housman, Cambridge, 1972, II, p. 715.

229 Hay que reconocer que el género epigramático se presta a ciertas efusiones no muy castas, y ello incluso en el seno de la Iglesia: en el ejemplar de la edición de Ramírez de Prado que conserva la Biblioteca Colombina (34-1-6) y que perteneció a D. Francisco Barbán (quien lo compró por cierto con "el librito de epigramas de Juan Oben" en Madrid el 12 de agosto de 1733 por dos pesos de a ocho reales de plata), se lee al margen de la p. 344 , comentando inmeiere $=$ futuere: "Hace a este propósito una epigramilla de un ingenio amigo: havía un estudiante grandisíssimo hablador, a quien por donaire llamaban el dómine Lavia; quería a una moçuela de buen parecer y díxola: "Bellísima Dorotea, / no lo creo, mas por Dios, / que me aseguran que en vos / el dómine Lavia-mea". Es un chiste típico de curas, por el juego de palabras entre Lavia mea y labia mea (Psalm. $59,17)$.

230 Queda en el aire si llegó a coger la alusión Calderini: "poeta uult ostendere Philenem habere uultum similem Priapo qui caluus, ruffus, luscus 
et exempli causa ponitur et sententiae, cum ab eo petat ut se fellet, quemadmodum facit Chione, quam fellatricem esse perspicuum est, inf. ep. 86 et 96" ("id est, si dederis, silebo, nam ut alibi ait, a Chione conducebatur ut futueretur", había comentado Calderini) o IV 36, 2 (p. 326): "existimo Poetam uoluisse grauius probrum tectis uerbis in Olum facere, quod hic Olus esset cunnilingus et hac de causa barbam tingere non posset, tum quod statim fucus ille frictu turpissimae illius actionis dilueretur, tum quod delicatae illae matronae nollent femina sibi illini medicamento tinctorio"231. En III 96, 3, sin embargo, donde los profesores parisinos y yo mismo le habíamos concedido la primacía en la recta comprensión del epigrama232, el sentido del mismo ya había sido captado por Demetrio Calderini: "Tacebis: alludit ad illud quod dixerat garris et ad fellationem, nam qui irrumantur dicuntur fellare, et loqui non potest ore mentula irrumatoris obstructo", insistiendo en la misma interpretación más adelante, al comentar IX 4, 4: "fellabat Galla irrumantem Aechylum. Qui fellat loqui non potest; ex hoc iocatur poeta, ut alibi Si te prendero, Gargili, tacebis"233. Las conjeturas valen mucho menos (Spect. XXIII 1 Norica por Dorica [p. 21]; I 41, 13 improbis por improbus [p. 75]; I 99, 9 partum por raptum [p. 128]; II 8, 6 Numne por Tunc [p. 152], provocando grandes aspavientos en "Musambert"; IV 58, 2 Nam por Num [p. 349]: "uide, Ramiresi, quàm caecus ritu Polymnestoris exoculati aut Siculi Cyclopis in

est". Hernando Colón fue apuntando: "calua es: scilicet sicut Priapus"; "ruffa es: scilicet sicut Priapus"; "lus<c>a es: orba oculo, sicut Priapus"; "fellat: quia nullum discrimen est inter te et Priapum". Imitó el poema -sin el tremendo final, claro estáBaltasar del Alcázar (157 [ed. de V. Núñez Rivera, Madrid, 2001, p. 488]).

231 Yerra "Musambert" en su explicación, "uera quidem et honesta": "Olus ille comam tingere potest quia comam alit; barbam non potest, quia non pascit barbam, neque ritus Romanus eam pascere sinit" (p. 159).

232 Ridiculiza Musambert las alegrías exegéticas de Ramírez de Prado: "Magnificè hypomnemate $\mathrm{XCV}$, postquam spurcissimè de priore et posteriore, de Venere Thespia et Cnidia commentatus est, gaudio gestiens gloriaris, neminem hoc praeter te subodoratum esse. Quid tu vis fieri? Non omnes possunt subodorari vnguenta ista exotica" (p. 151).

${ }^{233}$ Utilizo la edición de Venecia, 1480. Calderini (1446 Torri del BenacoRoma 1478), secretario de Besarión, dedicó el comentario a Marcial, realmente un portento de erudición, a Lorenzo de Médicis (1 de setiembre de 1473). Sobre su figura cf. A. Perosa, Dizionario biografico degli italiani, 16 (1973) 597-605. 
obuios parietes impingas", le espeta Rader [p. 336]; III 16, 1 sutorum, Regule, cerdo [p. 228]; III 19, 8 Comperit et por Dum perit o [p. 231]; III 60, 10 sit por est [p. 262]; кo algunos casos rozan lo imposible, como, p.e, la reposición del rebuscadísimo arcaísmo manus en II 91, 2 (manos deos 'buenos dioses' por magnos deos [p. 50, 216]; "meritò vapulat a Musamb.", comenta Rader [p. 241]): el puro estilo de Marcial huye de tales extravagancias, aunque D. Lorenzo fuerza la nota aquí y en otros pasajes (como en su explicación de effete en II 27, 3 [p. 166], aceptada sin embargo por Rader [p. 202]). Mejor es su uelamine por medicamine en III 3, 1 (p. 220), aceptado por la edición de Lemaire, o su durius por dulcius en IV 66, 2 (p. 354), a pesar de conocer el uilius de Gruter; y acierta al proponer ministro por el magistro de la vulgata en III 39, 1 (p. 244). En un caso, como ya se ha dicho, se adueñó de una enmienda ajena: aquis por equis en I 49, 4 (p. 84).

Aun tocó D. Lorenzo la interpretación de otros pasajes de Marcial en

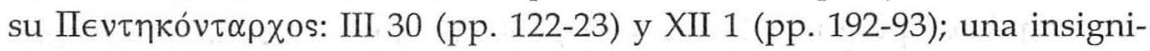
ficancia, en comparación con su esfuerzo anterior, en el que verdaderamente había volcado todo su ingenio, de suerte que sus extremos -y extravíos- de agudeza pasaron a ser proverbiales. No se comprende, si no, la acerada burla de Cervantes cuando, en el Quijote 234 nos presenta a un típico estudiante de Salamanca, un joven de diez y ocho años, a quien "todo el día se le pasa en averiguar... si Marcial anduvo deshonesto, o no, en tal epigrama". ¿No nos parece reconocer en este mozalbete inquieto y erudito a nuestro D. Lorenzo?

\section{La reacción de la Compañía: el padre Juan Luis de la Cerda (c. 1560-1643)}

La respuesta destemplada de D. Lorenzo a Rader lo indispuso con la comunidad jesuítica, incluso con miembros que antes lo habían tratado con consideración. Es de lo más significativo que el eruditísimo padre Juan Luis de la Cerda se sirviera en su comentario a Virgilio de la edición de Rader (alabado como "doctissimus Raderus" [III, p. 752 b]), sin mencionar siquiera la de Ramírez de Prado, a quien también condenó al olvido en el "Auctorum recentiorum qui hoc opere laudantur et a quibus

${ }^{234}$ II 16 (p. 756 Rico). 
adiuti sumus syllabus"; silencio quizás explicable por el escaso número de autores españoles que alabó en esta lista (sólo se salvan su compañero de orden M. A. del Río [llamado con satisfacción "Delrius noster" en I, p. 335 a, III p. 659], Juan Grial y Pedro Chacón)235. En su monumental obra La Cerda, muy orgulloso del enorme imperio concentrado gracias a la unión ibérica en la corona de Felipe III (los "Hispani" eran "vere nunc terrarum domini" [I, p. 220 b]) 236, aprovechó como es lógico a Marcial: citó a VIII 55, 12; VII 29, 7 para esclarecer la identidad de Alexis (I, p. 22 a); XII 31, 8 parua regna le sirvió de explicación a la rara aposición Buc. I 69 mea regna (I, p. 17 b); con XIII 38, 2 colostra glosó Buc. II 22 lac nouum (I, p. 28 a); interpretó marcentes... uuae V 78, 11 como 'pasas' (I, p. 276 a); dio a praetoria en X 79, 1 y en Georg. IV 75 el valor de "ampla aedificia" en el lenguaje agrícola (I, p. 446 b); insinuó la posibilidad de que en III 43, 3-4 se aludiera a la costumbre de Prosérpina: cortar un mechón de la cabellera del moribundo (II, p. 500 b); discutió (II, p. 52) el número de bocas del Timavo, siete (IV 25, 5-6; pero multifidum en VIII 2,7) o nueve (Aen. I 249); en Georg. I 192 (I, p. 214 a) defendió la lectura teret (en vez de ferit) en IX 90, 11; propuso interpretar quadram placentae (VI 75, 1) como la base para comer el tordo, remedando las famosas mesas de pan de Eneas (III, p. 22 b; para la quadra cf. III, p. 23 b); puso de relieve la rareza de la expresión tertia cena en XI 31, 6 (III, p. 194 a); en XI 50, 4 glosó la lectura de los códices (et uatem non minus ipse tulit) como "agellus Vatem tulit ['el propio campo produjo un poeta']", siguiendo la enmienda Arpino succurrere censuit agello de las ediciones antiguas en el v. 3 (III, p. 587); aceptó la conjetura de Scaliger en XII 21, 7 te (por cito) ridebit en defensa de Buc. IV 62 risere parentes ac. (I, p. 80 a); apuntó en XIV 138, 2 el juego etimológico entre laena/ $\chi \lambda \imath \alpha i v \omega /$ calfaciunt (II, p. 428 b); defendió un nuevo sentido y pienso que correcto para circulus en XIV 139, 2: "Hic enim non est circulus panis in rotunditatem formatus, ut male interpretes, sed is circulus quem format calix positus in mensa, saepe udus. Quasi dicat: tegant tibi lintea mensam tuam, quippe pretiosam ab ipsa materia;

${ }^{235}$ Utilizo la edición siguiente: P. Vergili Maronis Bucolica et Georgica, Lyon, 1619; P. Virgilii Maronis priores sex libri Aeneidos, Lyon, 1612; P. Virgilii Maronis posteriores sex libri Aeneidos, Lyon, 1619.

${ }^{236}$ Cf. asimismo los elogios de D. Juan de Austria (II, p. 594 b, 736 a) y de Hernán Cortés (II, p. 582 a). Es muy notable su defensa de la poesía española, que pone por encima de la italiana, en I, p. 486 b. 
nostrae mensae orbiculares non egent istis mantilibus" (I, p. 490 b) ${ }^{237}$; por fin, señaló algunas imitaciones virgilianas: litora myrtus amat IV 13, $6=$ Georg. IV 124, cf. II 112 (I, p. 278 a); plena... acerra IV 45, $1=$ Aen. V 745 (II, p. 593 b); Sophocleo... cothurno V 30, 1, cf. III 29, 7 = Buc. VIII 10 (I, p. 135 a); sacra... Maronis VII 63, 5 = Georg. II 476 (I, p. 331 a); Idumaeas... palmas X 50, 1 = Georg. III 12 (I, p. 348 b); spumantis apri XI 69, $9=$ Aen. I 328 (II, p. 66 b); repetita sequi XII 52, 8 = Georg. I 39 (I, p. 187 b); geminos... anguis XIV 177, 1 = Aen. VIII 697 (III, p. 268 b). Pero esta utilización de Marcial no se sale nunca de los límites de una pudibundez ruborosa; no en vano el jesuita confesó en una ocasión: "De deo Fascino veterum ego hîc nihil, consulens pudori" (I, p. 61 b); en ello imitó a su virginal Virgilio (III, p. 459 a).

A la Compañía de Jesús hubo de pertenecer el propietario del códice 4141 de la Biblioteca Nacional de Madrid, que ilustró con doctas y muy oportunas notas las poesías de B. L. de Argensola, citando entre los humanistas a Mureto (p. 28) y a Alciato (p. 413). Efectivamente, en el f. 179r escribió: "Vide Mart. Libr. 9. epig. 49 aliàs 70 et quae ibi adnotat noster Raderus. Quid tibi nobiscum est, ludi scelerate magister, invisum pueris virginibusque caput etc. Titulus epigrammatis est: In ludi magistrum"; y en el 348v: "De hac lege Julia vide Martialis epig. 5. lib. 6. et quae in eo commentatur noster Raderus, en que trata este punto con muy grande erudición"238. Otra nota al soneto "A un viejo enamorado" nos permite quizás adivinar la identidad del comentarista: "Este soneto es de la mano y letra de su author: embiómele con una carta suya a Burgos en Marzo de 1619, acabándolo de componer. Era en este tiempo el Dor Bartholomé Leonardo de Argensola canónigo de Zaragoza y Chronista del regno de Aragón" (f. 417r). Jesuita, amigo de Argensola y gentil latino: estos tres requisitos parecen cuadrar bien al padre Juan Luis de la Cerda.

237 Los editores de la colección Lemaire atribuyen a Escalígero esta interpretación, que hace suya modernamente Shackleton Bailey. No acierta en su traducción Yzaac.

${ }^{238}$ El códice, según se apunta en las hojas de guarda, "Es del rey Nuestro Señor. Compréle de los mss. de Barcia. Pellicer". Transcribió el segundo comentario J. M. Blecua en su edición de Argensola (Clás. Cast., I, p. 166). Citó este anotador a Marcial en el f. 53bisr, para documentar la costumbre de señalar un día alegre con una piedra blanca; cf. asimismo f. 172v, 212v, 419r, 426v, 441r. 
En suma, con insistencia significativa, la edición normativa para los españoles (y en especial para los jesuitas) es la de Rader, debidamente expurgada para no herir castas sensibilidades cristianas. Es, por dar, un ejemplo ilustrativo, la única extranjera publicada en el s. XVII que figura en la Biblioteca Capitular de la catedral de Sevilla; pero precisamente en el seno del cabildo hispalense nos aguarda una sorpresa.

\section{D. Manuel Sarmiento de Mendoza (1563-1645), traductor y comentarista de Marcial}

El ms. facticio 8276 de la Biblioteca Nacional, que perteneció al conde de Miranda, contiene en sus ff. 4r-21v unas "Declaraçiones del Marçial" en castellano, que explican sucintamente, sin pretensiones de erudición ni polémicas con comentaristas, el De spectaculis y I-IV 46, limitándose muchas veces a ofrecer una traducción ampliada del original. Doy algunos ejemplos:

I 65 Caeciliane, tuos] No dice Oracio que ficus por las almor $<\mathrm{r}>$ anas es masculino $\{\mathrm{s}\}$, sino esto: los igos diremos ficus y a los tuyos y a tus criados y los de tu casa ficos, porque todos tienen almorranas; vide .li. 7. ep. 70 (f. 8r).

I 92 Tangi se] Quéxase mi muchacho que le hazes amores y le andas tentando; todo te lo daré si ninguna otra cosa te falta. Nudi grabati] pero ni tienes ogar ni una triste camilla, ni aun un jarro desportillado en que vever como el de Chione y Antiope, mujercillas. Trita lacerna] no tienes \{tiene\} aun una vestidura raída, y la capa te cubre media nalga y no más, como las de françeses. Pasceris] y te sustentas con sólo el olor de las cozinas y bebes de los charcos. Non culum] Ese tu no culo, porque no lo es que no caga, porque no comes. Con el dedo te sacaré ese ojo. Satur] Ártate y yo te le daré (f. 9r).

II 17 Tonstrix] La barbera que vive en la voca de la calle de Suburra allí adonde están colgados los azotes de los que se alquilan para azotar los esclavos de los otros, y donde ay muchos zapateros, no barbea o corta si rae, porque pela muy bien a todos (f. 11r).

III 92] Ruégame mi mujer consienta al adúltero; pero si yo le cojo, no le quitaré dos ojos sino uno: mentulam abscindam.

IV 19] Envíote en presente esta vestidura extranjera franzesa, grosera y basta y de poco valor, pero no mala para los fríos del invierno. Es buena para arroparte quando as luchado, jugado a la pelota o al belorto, o quando as corrido, para que no te entre el frío estando sudando ni te cale el agua; no se te dará del viento ni aguas un quarto teniendo esta vestidura, ni estarás más guardado con una de Tiro (f. 20v). 
Según el Índice manuscrito de la Biblioteca Nacional y la Enciclopedia Espasa ${ }^{239}$, el autor de las Declaraciones fue D. Manuel Sarmiento de Mendoza, maestro de Teología por Salamanca y canónigo primero de Jaén y después magistral de Sevilla (19 de junio de 1600) ${ }^{240}$. Si ello es verdad, tienta la idea de atribuir al canónigo unas traducciones de Marcial que guarda el ms. BN Madrid 3911, del s. XVII. Hay una coincidencia llamativa que parece corroborar la identificación. Sarmiento sufrió ciertos desaires en la Corte, según se desprende del Memorial o discurso en satisfacción de algunos cargos que se le hacen encabezado al Conde-Duque sin fecha, pero que acompaña a la impresión de las cartas que le dirigió el canónigo el 30 de abril de 1630 y el 8 de julio de $1632^{241}$.

${ }^{239}$ LIV, s.v., p. 611.

${ }^{240}$ En 1630 trazó su biografía F. Pacheco, Libro de retratos, Madrid, 1983, pp. 119-20. Recogió diversos datos sobre su actuación en el cabildo catedral hispalense J. Hazañas, Vázquez de Leca. 1573-1649, Sevilla, 1918, pp. 456-58. Las pruebas de sangre del candidato a magistral que, comisionado por el cabildo hispalense, llevó a cabo D. Diego Osorio de Ulloa, arcediano de Écija, en Burgos (diciembre de 1600) y en Castrofuerte (enero de 1601), se conservan en A.C.S., Sección I, M-6. Procedía D. Manuel de una rancia estirpe burgalesa por parte de padre: era hijo de D. Antonio Sarmiento, comendador de Santiago, caballerizo mayor de la princesa $D^{\mathbf{a}}$ María, natural de Burgos, y de $\mathrm{D}^{\mathrm{a}}$ Isabel Barba de Campos, señora de las villas de Castrofuerte y Fael, natural de León. La familia Sarmiento se había trasladado a Sevilla hacia 1577: el tío de D. Manuel, D. Francisco Sarmiento, fue obispo de Jaén desde 1580 (cf. el elogio del pintor Pacheco, ibidem, pp. 191-93). Otro hermano del magistral, D. Gregorio Sarmiento, fue coadjutor de D. Mateo Vázquez de Leca; pasó las pruebas en febrero de 1607. Tanto D. Manuel como D. Gregorio estudiaron en Salamanca, donde el primero fue rector dos veces.

${ }^{241}$ Los cargos que le hacía el Conde-Duque eran tres: que Sarmiento había regresado de Madrid a Sevilla sin besarle la mano, después de haber pasado dos años en la Corte negociando asuntos del cabildo hispalense; que la dedicatoria de la Milicia era una sátira (se hablaba en ella de "la buena dicha" del valido, palabras que se interpretaron como excluyentes "de industria, de méritos, de prudencia" y equivalentes a "fortuna ciega"); y que el rey no le hacía merced (había pedido Sarmiento la comisaria general de la Santa Cruzada, el cargo de archimandrita de Sicilia o la Capellanía mayor de Nuestra Señora de los Reyes de Sevilla), "porque en los negocios que se ofrecían no le servía". 
Pues bien, el origen de la versión se debió precisamente a una desgracia: "mi intento fue divertir una melancolía, procedida del agrabio que es bien notorio a los más ignorantes" (f. 1v).

La traducción tiene ciertos vuelos literarios y está muy lejos de la gazmoñería pacata del jesuita aleman, a quien se censura abiertamente (f. 2r), tal vez por ser pariente el canónigo -por la rama de los Orense- de Ramírez de Prado: "Alabo la religiosa honestidad de Radero, mas cansa su demasiado escrúpulo quando deja de traducir la 25 en el lib. spectac... Y no fue menor niñería quitar dos versos en la ep. 120. lib. .1., donde dice que la Isa de Publio... No es mi intento embarazarme en su censura (de que se escapa por aber nacido alemán)". Con objeto de incluir en su selección el mayor número posible de epigramas evitó Sarmiento la traducción directa de ciertas palabras, que se dejan púdicamente en latín (así mentula). Como prueba de sus virtudes y defectos puede valer la versión de XII 59 (ff. 153v-54r), que salta por encima de algunas dificultades, pero no rehúye los pasajes escabrosos:

El que de Roma se ausenta

más besos halla a la entrada, que los que Lesbia rogada a Catulo dio sin quenta.

Aun no bien abrás llegado, quando el varrio se te arrima y tu gañán te lastima, más cerdoso que barbado.

El tejedor se atrabiesa y el que los paños te laba y el zapatero, que acaba de besar las pieles, besa. Otro barbado piojoso te ensucia y provoca a enojo.

Otro llega con un ojo, y tras él un zegajoso.

Entre toda esta rebuelta me faltaba lo peor: del que lame y felador. Cara te costó la buelta. 
Que D. Manuel fue todo un enamorado de Marcial ${ }^{242}$ se demuestra en el libro intitulado Milicia evangélica para contrastar la idolatría de los gentiles, conquistar almas, derribar la humana prudencia, desterrar la avaricia de ministros (Madrid, 1628), una especie de "arte de navegar predicadores" que el canónigo dedicó al Conde-Duque urgiendo a predicar el Evangelio en Japón y China ${ }^{243}$. El tema, polémico -se comenzaba a discutir entonces la necesidad de cerrar la misión en el Japón, tierra regada con la sangre de no pocos religiosos y seglares-, no convidaba a alegrías; y, pese a todo, se citan varios epigramas de Marcial, sin venir mucho a cuento, para

${ }^{242}$ Hubo de influir en esta predilección el hecho de que Marcial fuera español; a D. Manuel se le llena la boca cuando habla de "aquel gran filósofo español Séneca" (Milicia evangélica, f.102v).

${ }^{243}$ También se distinguió Sarmiento por sus dotes de predicador. He visto las siguientes obras suyas:

Sermón que predicó... en las Onras que se hicieron en ella [la catedral] a la sereníssima Margarita de Austria, Reyna de España, a don Pedro de Castro y Quiñones, Sevilla, 1611. Tema: Ioh. 11, 26 Qui credit in me, non morietur in aeternum.

Sermón que predicó... en la Santa Iglesia metropolitana de Sevilla, Domingo de la Octava del santíssimo Sacramento a primer de Iunio. 1614. años, al conde de Niebla, gentilhombre de cámara de Su Magestad, Sevilla, 1614. Tema: Ioh. 6, 56 Caro mea verè est cibus et sanguis meus verè est potus.

Sermón que predicó... en San Vicente, a la fiesta de la Inmaculada Concepción de la Virgen María, Sevilla, 1615. Tema: Matth. 1, 26 De qua natus est Iesus qui vocatur Christus.

Sermón que predicó... el día octavo de las fiestas de la Inmaculada Concepción de nuestra Señora de la Cofradía de Sacerdotes de la Vincula de San Pedro, en su Parroquial Yolesia, Domingo veynte y seys de Iunio de 1616, a Don Mateo Vázquez de Lecca, Arcediano de Carmona, Sevilla, 1616. Tema: Matth. 1, 26 De qua natus est Iesus, qui vocatur Christus.

Sermón que predicó... en el convento de monjas Augustinas de S. Leandro, día de S. Agustín, este año de 1623, dedicado al ilustríssimo señor don Andrés Pacheco, obispo de Cuenca, Inquisidor General, Sevilla, 1623. Tema: Matth. 5, 14 Vos estis lux mundi.

Sermón que predicó en la fiesta de San Ignacio fundador de la Compañia de Iesús en treynta y uno de Iulio en la Casa Professa.... dirigido al Excelentísismo señor don Rodrigo Ponce de León, Duque de Arcos del insigne Orden del Tusón de Oro [de quien era capellán], Sevilla, 1624. Tema: Luc. 12, 35 Sint lumbi uestri praecincti, et lucernae ardentes in manibus uestris.

En todos ellos hay citas de autores clásicos, pero no de Marcial: así lo pedía el género concionatorio, más grave y majestuoso. 
apoyar diversas interpretaciones: V 5, 8; 30, 1; VIII 3, 13;18, 8 para glosar las palabras de San Pablo (Eph. 6,15) Calceati pedes in praeparatione Evangelii pacis (f. 7r); XIII 98 para probar que "nunca se habla de ella [la cabra], sino en ocasión de caça" (ff. 22v-23r); y, por fin, I 8 para indicar que "no es el morir el mayor trabajo... sino el vivir muriendo en penalidades".

Sarmiento de Mendoza y su concanónigo D. Juan de Fonseca y Figueroa (1585- Madrid 1627), amigo de Ramírez de Prado ${ }^{244}$ y protector de Velázquez ${ }^{245}$, fueron los miembros más cultos de la Iglesia hispalense: a ellos entregó el cabildo en 1611 los papeles de Colón, para que ambos hicieran las diligencias pertinentes en defensa de la Biblioteca Fernandina, hoy mal llamada Colombina. Por otra parte, D. Manuel gustó de intervenir en las polémicas de su tiempo. Se levantó una gran polvareda cuando Pacheco pintó a Cristo crucificado con cuatro clavos, ya que algunos (como el duque de Alcalá) defendían que lo había sido sólo con tres, como requería el simbolismo trinitario. Avaló a Pacheco nuestro Sarmiento el 15 de enero de 1622.: "lo natural y forzoso parece haber de clabarse con dos clabos los pies y casi imposible clabarlos con uno"246. A su vez, el pintor dedicó un bello elogio a su amigo: "Bien pudiera este insigne varón dar a la estampa un gruesso tomo de materias escolásticas sobre Santo Tomás, digno de su autor, como hazen otros, que compran escritos agenos para acreditarse. No ignora los caminos del negociar por la experiencia que tiene, antes se juzga por más dichoso en la medianía [la aurea mediocritas horaciana], donde se halla quieto y seguro y no se teme deslizadero".

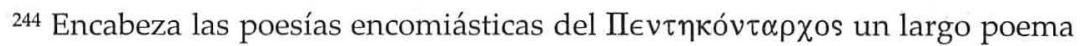
en dísticos de D. Juan de Fonseca a Ramírez de Prado, "amico suo", a quien llama "Nobilitatis honos, Patriae lux, gloria, cultor". El canónigo, sin embargo, se zafó de tener que comentar los falsos cronicones. Como confiesa Tamayo en su prólogo a las Novedades antiguas de España, hacía años que había pedido que ilustrara la Cronica de Dextro a D. Juan de Fonseca y Figueroa, sumiller de cortina del rey y su embajador extraordinario en Parma; pero éste había dado la callada por respuesta.

245 Cf. J. López Navío, "D. Juan de Fonseca, canónigo maestrescuela de Sevilla", Archivo hispalense, 126-27 (1964) 83-126.

246 A.C.S., ms. 85-4-2, f. 107r. Lo reprodujo Pacheco en El arte de la pintura (cf. la excelente edición de B. Bassegoda, Madrid, 1990, p. 737). 


\section{D. Manuel de Salinas (1616-1688). Otros traductores}

Otro canónigo compitió con Sarmiento de Mendoza en traducir a Marcial. Si hoy conocemos sus versiones, que también quedaron inéditas, es gracias a Baltasar Gracián, pues normalmente el jesuita gustó de añadir a sus citas de epigramas latinos la traducción del: "canónigo [de Huesca] D. Manuel de Salinas y Lizana, que assí en este como en los de Marcial felizmente juntó lo ingenioso de su mente y lo sabroso de su nombre" (Discurso II [p. 5]). Doy dos pruebas del talento de Salinas como traductor en redondillas ${ }^{247}$ :

Discurso IV (p. 15) = Mart. I 31:

$$
\begin{aligned}
& \text { Diaulo es oy sepulturero } \\
& \text { y ha poco que era Dotor: } \\
& \text { lo que haze enterrador } \\
& \text { hizo Médico primero. }
\end{aligned}
$$

Discurso V (p. 24) $=$ Mart. II 80248:

$$
\begin{aligned}
& \text { Fannio ansioso por huir } \\
& \text { Del que su muerte procura } \\
& \text { Se mató. ¿No es gran locura } \\
& \text { Matarse por no morir? }
\end{aligned}
$$

Otras traducciones de Marcial se encuentran en el ms. BN Madrid 2341, f. 211ss. (s. XVII-XVIII).

\section{Bartolomé Jiménez Patón}

Un enamorado de Marcial fue el maestro Bartolomé Jiménez Patón (1569-1640)249, un gramático humanista al que sus discípulos saludaron

247 Pablo Cuevas Subías presentó en 2000 una tesis doctoral en Zaragoza sobre La vida y la obra de Manuel de Salinas y Lizana (1616-1688), publicada en CDRom; ahora prepara una nueva edición en papel, que saldrá a la luz en la colección "Larumbe" de las Prensas Universitarias de Zaragoza a finales de 2003.

${ }^{248}$ Otras traducciones en diferentes metros (sonetos, décimas, etc.) en p. 17, $2834,42,45,47,50,57,62,75,77,84,89,93,101,104,106,107,112,113,115,117$, 119 bis, 123, 141, 142, 144, 148, 149, 153, 156, 153, 160, 163, 174, 177, 190, 198, 200, 210, 222, 245, 261, 265.

${ }^{249}$ Utilizo una edición falta de la portada, pero que parece ser la de Baeza de 1615. Corrijo en los textos latinos las erratas evidentes. El conocido humanista no 
como un nuevo Quintiliano y algunos, más entusiastas, como un nuevo Platón por aquello del sonsonete ${ }^{250}$. En 1621, avecindado en Villanueva de los Infantes, Patón dio a la luz la obra de retórica que le habría de reportar más fama ${ }^{251}$. En la parte dedicada a la Eloquentia romana no faltan frecuentes alusiones a Marcial (f. 212, 217, 218, 219, 221, 222 y passim) y hasta se hace un comentario más por extenso de VII 57 ("Sententia ergo erit, Gabinia faemina tot et tantis muneribus donauit Achilem, hoc est, iuuenem pugilem, ut receptus fuerit in ordinem equestrem"), sin percatarse de las alusiones obscenas contenidas en el dístico. Siendo notario del Santo Oficio, catedrático de Latinidad y correo mayor de la misma villa, es decir, todo un personaje, Patón publicó, a costa normalmente de sus antiguos alumnos, una serie de breves comentarios a Marcial que hubieron de ver la luz en aquella década fructífera: 1628 es la fecha del único que está datado. Estos folletos, hoy rarísimos, versan sobre los siguientes temas:

1) Declaración magistral de la Epigrama de Marcial, 60. lib. 4. ocasionada de auerse preguntado qué quiso dezir el Poeta en el fin d'ella In medio Tybure Sardinia est, por el Maestro Bartolomé Ximénez Patón, en su estudio de Villanueva de los Infantes, al Doctor Don Pedro de Ávila, Abad mayor de la santa Iglesia del sacro monte Illupulitano de Granada. "Sardinia dixo por la muerte, porque es ello assí, que esta isla es muy enferma y pestilencial" (f. 15v); sigue una larga disertación sobre el Sardonicus risus.

fue un buen alumno en la Universidad (cf. J. Higueras Maldonado, "El humanista Ximénez Patón (1569-1640). Su presencia en la Antigua Universidad de Baeza (Jaén)" en Humanismo y pervivencia del mundo clásico. Homenaje al Profesor Luis Gil, Cádiz, 1997, II 3, p. 1192).

250 "Alter Quintilianus" lo llamó el presbítero Miguel Díaz-Castellanos, mientras que el licenciado D. Antonio Castillo del Busto ("nomine Patonis, Plato secundus eris") y Juan Aguilar, profesor de buenas letras en Antequera, lo compararon con Platón ("Fas igitur nobis sit te appellare Platonem"), en epigramas laudatorios que se encuentran en el volumen facticio BN R/13210, al que van referidas las siguientes citas. Allí se hace mención de otros discípulos: Juan Fernández, el licenciado Antonio del Castillo y Bustos, Don Juan de Salinas y de la Cerda, Antonio Martínez de Miota y Domingo de la Muela.

${ }^{251}$ Mercurius trimegistus siue de triplici eloquentia sacra, española, romana, Opus concionatoribus verbi sacri, poetis utriusque linguae, diuinarum et humanarum literarum studiosis vtilissimum ad D. Thonnem de Tarsis, comitem de Villamediana, Archigrammatophorum Regis, Baeza, 1621. 
2) Declaración magistral de la Epigrama de Marcial Lib.3. Epist. 41 [= 40] A Don Juan de Salinas y de la Cerda, Don Juan de Salinas y de la Cerda su hijo. Sobre Méntor, Mío, Policleto, etc., grandes artistas en "debuxar en metal", y sobre los lagartos.

3) Declaración magistral de la Epigrama 2.5. [= 24] de Marcial lib. 1, a Don Fernando Chacón de Naroáez, Canónigo de la santa Iglesia de Antequera. Contra la hipocresía de los bujarrones. Está publicado en el año 1628.

4) Declaración magistral del dístico de Marcial Lib. 77. Epig. 5. [= V 75], al Licenciado Don Antonio del Castillo y Bustos. Sobre la lex Iulia y el castigo del adulterio.

5) Declaración magistral del dístico Epigrama de Marcial lib. 1. ep. 6 [= I 5], a Don Juan Chacón Naruáez y Salinas. Sobre las fiestas celebradas por Domiciano en el anfiteatro y el castigo dado a las malas poesías.

6) Declaración magistral de la Epigrama 75. de Marcial libr. 13. al Reuerendíssimo Padre Fray Juan Baptista Sánchez, Prouincial de su Religión del Seráfico Padre San Francisco en su Prouincia de Cartagena. Sobre las grullas y su vuelo; valor simbólico de la letra Y.

7) Declaración magistral de la Epigrama 33. [= 32] de Marcial lib. 5. A don Agustín de Hierro y Medinilla, Colegial mayor en el de Santa Cruz de Valladolid y en su Vniuersidad Catedrático de Vísperas de Cánones. Diversos valores de quadrans, "quarta parte de la hazienda"y de la serie triunx, quincunx, semis, bes, dodrans, dextans, deunx; varios tipos de testamentos.

8) Declaración magistral de la Epigrama 20. de Marcial lib. 9 al Dotor don Paulo de Córdoua y Valencia, Canónigo de la Santa Yglesia del sacro monte Illipulitano y Consultor del santoficio [sic] de la Inquisición de Granada. Sobre las "sombras" en los convites; costumbres del banquete (estar descalzo, lavar los pies, etc.).

Como se ve, los ensayos no contienen ningún descubrimiento, pero se leen con gusto, adobados como están con noticias curiosas de su tiempo. Así, al hablar de los lagartos se añade que "en la India los ay muy grandes [i.e., los cocodrilos], cuyas pieles llenas de paja se han traído a España" (f. 22) o se nos informa de que "del sobrenombre Marcial ay oy muchos en su prouincia de Aragón" (f. 33v). Sus etimologías las podía haber hecho un San Isidoro: a su entender ardelio, "mequetrefe, bailador, inquieto, neverete, livianillo", viene de ardea, 'garza real' (f. 14r).

Los autores latinos sirvieron entre otras cosas para hacer colecciones de sentencias y aforismos. Lo que nunca se había hecho era buscar 
correspondencias latinas a la rica literatura moralista del Siglo de Oro. Eso fue precisamente lo que hizo nuestro Patón, en un verdadero alarde de virtuosismo, con los Proverbios morales o Heráclito de Alonso de Barros (1552-1604). En la obra resultante, los Proverbios concordados, el maestro giennense presentó a doble página el apotegma original castellano y su posible correspondencia latina, a veces muy traída por los pelos. A los 1100 proverbios de Barros Jiménez Patón halló sólo 19 equivalencias en Marcial, proporción pequeña, mas por lo general acertada: así, p.e., el no 842 refleja bien el sentimiento de superioridad del hombre sobre la mujer, tan característico de la Antigüedad y de la cultura cristiana. Las coincidencias tomadas de Marcial son las siguientes:

103 (f. 9r): securus nullos resalutas, despicis omnes (IV 83, 3): “Ni vana ambición concede / recíproca cortesía".

127 (f. 11r): Gaudia non remeant, sed fugitiua uolant (I 15, 8): "Ni puede el bien que es passado, / dar gozo en el mal presente".

238 (f. 18r): Habet Aphricanus millies et tamen captat. / Fortuna multis nimis dat, satis nulli (XII 10): "Ni satisface al desseo / lo que nos puede faltar".

338 (f. 26r): Debet Aricino conuiua recumbere cliuo Iquem tua foelicem, Zoile, caena facit (II 19, 3): "Ni manjar con su sabor, / si se come á mesa agena".

376 (p. 28r): Aprum amat et mulos et sumen et ostrea (IX 14, 3): "Ni tiene el pez ó animal / paz, no estando el hombre ahito".

619 (f. 46r): Extra fortunam est quidquid donatur amicis: / quas dederis solas semper habebis opes (V 43,7): "Ni es razón que nadie gaste / su hazienda con poquedad".

624 (f. 46r): Sera nimis vita est crastina, uiue hodie (I 15, 12): "Ni se deuen diferir / las cosas para mañana".

679r (f. 50r) Et iudex petit, petit et patronus. / Soluas, censeo, Sexte, creditori (II 13, 2): "Ni acredita el diferir / las pagas al mercader".

764 (f. 56r): Non omnes fallis, scit te Proserpina canum. / Personam capiti detrahet illa tuo (III 43, 3-4): "Ni falta engaño y fición / sino solo en el morir".

812 (f. 58r): Semper eris pauper, si pauper es, Aemiliane (V 81, 1): "Ni ay desdicha quando empieça / que en todo no se empeore".

821 (f. 59r): Per conuiuia, porticus, theatra, / delectas, Philomuse, non amaris (VII 76, $1 ; 6)$ : "Ni que el otro sea truhán / por ser solo combidado".

824 (f. 59r): Saepe fluunt gaudia imo sic quoque lapsa sinu (I 16, 19): "Ni es visto ningún placer / que dure si quiera un ora".

835 (f. 59bis): Sint Maecenates, non derunt, Flace, Marones, / Vergiliumque tibi uel tua rura dabunt (VIII 55, 5-6): "Ni aventajado interés / qual premiar à un coronista". 
842 (f. 60r): Inferior matrona suo sit, Prisce, marito: / non aliter fiunt foemina uirque pares (VIII 12, 3-4): "Ni puede ser bien casada / la que no tiene paciencia".

881 (f. 62r): Et Sacro decies repetis Pallatia cliuo Sigeriosque meros Partheniosque sonas (IV 78, 7-8): "Ni priuado que no haga / de sus fauores alarde".

927 (f. 66r): Sed nihil omnino te recitante placet (III 45, 4): "Ni ay ombre mal recebido / que acierte en cosa que hable".

1038 (f. 74r): Dum modo Lucrino, modo se permittit Auerno, / Penelope uenit, abit Helene $(\mathrm{I} 62,6)$ : "Ni santo entre tanta gente / que buelua tal como vino".

1061 (f. 75r): Nolo uirum facili redimit qui sanguine famam; / hunc uolo laudari qui sine morte potest (I 8,5-6): "Ni imagino que es grandeza / dar por la onra la vida".

1093 (f. 78r): Qui sua metitur pondera ferre potest (XII 98, 8): "Ni intenta perder la palma el que primero se prueba".

\section{D. José Antonio González de Salas (¿1591?-1651)}

D. José Antonio González de Salas, el gran humanista y amigo de Quevedo, escribió un Marcial redivivo, hoy perdido al parecer ${ }^{252}$, buena prueba de su aprecio por el bilbilitano, a quien valoró, como todos sus coetáneos, por su condición de español: a lo largo de su monumental comentario a Petronio (Francfort, 1629)253. Marcial es para él "Hispanus epigrammatista" (p. 80 b) o "Valerius noster" (p. 84 a), igual que Séneca es "Hispanus philosophus" (p. 119 b, 136 a) o "Seneca noster" (p. 90 b), Lucano "Cordubensis poëta" (p. 121 b) o "noster Annaeus" (p. 245 b) e Isidoro "Hispanus Isidorus" (p. 126 a). Otra vez nos sorprende que Salas no cite para nada a Ramírez de Prado ${ }^{254}$, y es más, que le lleve la contraria

${ }^{252}$ Cf. J. Nowicki, Die Epigrammstheorie, p. 96. F. Moya, "Salas, un humanista al trabajo" en Humanismo y pervivencia del mundo clásico. Homenaje al Profesor Luis Gil, Cádiz, 1997, II, 2, p. 456 y 464ss., considera que se trata de las traducciones de Marcial incluidas en su edición del Parnaso.

${ }^{253}$ Cito por la edición Titi Petronii Arbitri Satyricôn quae supersunt cum integris doctorum uirorum commentariis et notis.., curante Petro Burmanno, ed. altera, Amsterdam, 1743. Sobre su autor cf. los documentados artículos de F. Moya (ya citado) y de J. López Rueda, "Joseph Antonio González de Salas, un filólogo clásico amigo de Quevedo" en A. Fontán- J. López Rueda-L. Gil, Tres grandes humanistas españoles, Madrid, 1975, p. 37ss.

${ }^{254}$ Menciona, en cambio, a "Ludovicus de la Cerda, vir summa eruditione conspicuus" (p. 176 a, cf. p. 240 b) y a Tomás Tamayo de Vargas, "Hesperiae nostrae decus" (p. 257 a, cf. p. 267). 
sin decirlo: hemos visto lo que significaba para D. Lorenzo rudis toga; pues bien, D. José concuerda con Rader y escribe: "rudes lacernae sunt Martiali nouae, uti et rudis toga" (p. 122 b) ${ }^{255}$. Enfrentado a un problema lexicográfico, el significado de pluteo en III 91, 10, había comentado Ramírez de Prado: "videor mihi colligere cubiculares lectos ab una parte, anteriori aut posteriori, pluteum habuisse, qui eam partem lecti veluti sepiret" (p. 182); lo corrige tácitamente González de Salas: "ac cujus inlustrationem nimis quam adpositum est illud veteris interpretis Persii ad Satyr. I. Sponda est exterior pars lecti, pluteus interior" (p. 222 b; "sponda lecti", había comentado Calderini). Al final de la obra, una parte muy obscena del Satiricón, Salas propuso ingeniosas explicaciones a diversos pasajes de Marcial, sacándoles asimismo un sentido indecente, hasta el punto de que el propio comentarista sintió vértigo ante esta catarata de procacidades escabrosas: "Sed ohe, nonne satis est impudicitiarum? (p. 285 a)". Los términos comentados son rufa (II 33, 2) = del color del falo priápico (p. 285 a), lusca del mismo epigrama (II 33, 3) que hace que Filénide, cuya cara es un puro falo (otra vez es ignorado Ramírez de Prado, cuya interpretación se acepta), se parezca a la lusca mentula (IX 37, 19, XI 73, 6, cf. Petr. 132, 11 [p. 272 a]), si sapis (II 41, 1) "arte quadam, ei etiam adhibitis magistris" (p. 258 a), diserta (XI 19, 1) "dictum de nequitiarum peritia (p. 288 b), aluta (XI 60, 3 = lorum in aqua Petr. 134, 9 [p. 274 b]; "languentem mentulam" Calderini).

\section{Francisco Cascales (¿1564?-1642) y Marcial}

Amigo de Ramírez de Prado fue al parecer el licenciado Cascales. A pesar de sus afinidades filológicas, sin embargo, no aparece el nombre de D. Lorenzo en las Cartas de Cascales (1634), ni siquiera en los pasajes en que hubiera sido de esperar una alusión, como cuando se diserta sobre las horas y la distribución del tiempo ${ }^{256}$. Silencio extraño, pero que tal vez

255 Otra alusión a Rader en p. 197 b. Entre los comentaristas a Marcial se cita a Grutero (p. 216 a).

${ }^{256}$ Cartas, III, p. 92ss. (ed. de J. García Soriano). Una nueva edición prepara S. Ramos Maldonado, que hizo su Tesis de Licenciatura en 1991 sobre Epigramas del humanista murciano Francisco Cascales. Introducción, edición crítica, traducción, notas e indices, bajo la dirección de J. M. Maestre Maestre. Cf. asimismo sus 
no lo sea tanto si se tiene en cuenta que el humanista murciano, tan aficionado a Marcial y él mismo donoso epigramatista latino, defendió en II 16, 3 la lectura correcta Sidone por el sindone que se leía en las ediciones antiguas ${ }^{257}$ y en la del propio Ramírez de Prado ${ }^{258}$ (cf. asimismo XI 1, 2); y a ello se añade que, según el Brocense, seguido asimismo por D. Lorenzo (p. 158), en ese mismo verso tinctus era un sustantivo (= tinctura), construcción (o "destrucción", como la denominaba graciosamente el licenciado) de la que se había burlado Cascales. Quandoque bonus dormitat Homerus, sí; pero con el maestro se había echado una larga siesta el discípulo. ¿Dardo envenenado de Cascales? Quizá.

El licenciado "marcializó", como él mismo dijo en un verbo de su invención, en 44 epigramas, "si no con su agudeza, con menos lascivia"259: la suprema aspiración entonces de todos. Entre los poemas enviados a Jiménez Patón se encuentran varias contrahechuras de Marcial (XV [II, p. 229] $=$ Spect. I; XXVIII [II, p. 247] = XI 18), pero prefiero transcribir la burla contra un gramático que cometía errores de prosodia y de sintaxis al versificar en latín (XIX [II, p. 234]), para poderlo medir y comparar con una composición posterior dedicada al mismo tema:

Vix epigramma tuum vidi, cum crimina centum

Vidi, Torrella judice grammatico.

Non omnes arbusta juvant humilesque myricae

.Dixit Virgilius, serpere Flaccus humi.

artículos "Figuras del motejar y técnica satírica en los epigramas del humanista murciano Francisco Cascales" en E. Sánchez Salor- L. Merino Jerez- S. López Moreda (eds.), La recepción de las artes clásicas en el siglo XVI, Cáceres, Universidad de Extremadura, 1996, pp. 525-531 y "Ausonio en el epigrama latino humanista y su influencia en el humanista murciano Francisco Cascales", Myrtia XI (1996), pp. 87-117.

257 Pero ya Calderini, aun imprimiendo en el texto sindone, había anotado: "quid faciat torus tinctus. Sidone olenti, id est, purpura uel tigus, nam tigus ornamenti genus erat appellatione barbara; autor Varro. Sindon est genus lini subtilissimi, ut legas quid tigus faciet confectus sidone, lino subtilissimo. Le contestó Mérula: "Sidone olenti. Tibi non credo, qui pleraque omnia uanissime effutis, nisi scriptorem dederis, qui haec dicat. Inuenio apud scriptores Graecos, in primis apud Libanium, sidonem pro uello subtilissimo accipi; in quam significationem uenit illud Euangelii ubi narratur corpus domini inuolutum fuisse sindone".

${ }^{258}$ Cartas, I, pp. 105-08.

${ }^{259}$ Cartas, II, p. 213. 
Tu tamen hos sacros vates, duo lumina Pindi,

Aversans primus protrahis humiliter.

Aut prodesse volunt aut delectare poetae

Idem Flaccus ait; tu prosit esse tuus.

Sed liceat breviare prosit, permittimus istud

Tam tibi quam pueris. Quis ferat esse tuus?

Esse tuum Latiae cogunt te dicere leges,

Aut hoc dicendi dic genus esse tuum.

Los versos están bien construidos y tienen gracia. Sin embargo, la poesía no resiste la comparación con un epigrama de Porson sobre un tema parecido ("On a fellow of Trinity, who always pronounced the 'a' in Euphrates short"), alado dístico que reúne las tres condiciones de un epigrama, breuitas, argutia y lepor:

Venit ad Euphraten. Rapidis perterritus undis,

Vt cito transiret, corripuit fluuium ${ }^{260}$.

\section{Las supercherías del jesuita Jerónimo Román de la Higuera}

El culto que sintió Ramírez de Prado por Marcial tuvo un efecto colateral, como ahora hemos aprendido a decir, en su círculo más íntimo de amigos y clientes. En efecto, entre los allegados de Prado militó el conocido jesuita Jerónimo Román de la Higuera, famoso por su producción infatigable de falsos cronicones. Hasta entonces, Román de la Higuera había utilizado para sus espúreos fines a Marcial, si bien de una manera moderada y parca: así en la Crónica que atribuyó a Dextro. En el último engendro de su pluma, sin embargo, el Cronicón de Julián Pérez, supuesto arcipreste de la iglesia toledana de Santa Justa, Román de la Higuera convirtió al epigramatista en uno de sus informantes preferidos. Bien se echa de ver que la edición -o la amistad- de D. Lorenzo había despertado el interés por el poeta. Después, como sobrevenido del cielo, el propio Ramírez de Prado sacó el Cronicón pereziano del polvo en que estaba sumido en la Biblioteca del Conde-duque de Olivares, lo dio a la

${ }^{260} \mathrm{H}$. Ph. Dodd, The Epigrammatists, Londres, 1876, p. 472. El editor pone el punto al final del primer verso. Eúphrates pronunciaban Spenser y Shakespeare (Antony and Cleopatra, I 2). 
luz y lo glosó con breves notas en $1628^{261}$ : una historia demasiado bonita para ser verdad. De lo que no cabe dudar es de que D. Gaspar de Guzmán poseía una copia manuscrita del último invento jesuítico, pues en el Prólogo a sus Novedades antiguas de España (Madrid, 1624) Tamayo de Vargas mencionó la Crónica de Julián Pérez, cuya "parte principal conserva la librería insigne del Excmo. Sor. don Gaspar de Guzmán", biblioteca que estaba entonces al cuidado del licenciado Luis Tribaldos de Toledo ${ }^{262}$, el futuro cronista de Indias: en ese círculo se coció la impresión de la superchería. D. Lorenzo, muy patriota, le tomó el gusto a ensalzar las glorias españolas, ahora multiplicadas por cien gracias a las malas mañas del jesuita -en las cuales alguna mano hubo de tener-, y andando el tiempo volvió a editar - o mejor dicho, a reeditar- otro monstruo higueriano: el Cronicón de Liutprando, que publicó con comentario suyo en Amberes en 1640 "ex officina Plantiniana Balthasaris Moreti". La elección de Marcial como fuente de supercherías no estaba mal pensada ni mucho menos, como vamos a ver muy luego.

Por los epigramas, en efecto, desfila un sinfín de personajes. No es de extrañar que más de un lector, intrigado por la identidad de este gentío variopinto, se preguntase por la posibilidad de que hubiese algún cristiano entre tanto personal. El más osado, Claverio, no vaciló en dar a esta pregunta una respuesta afirmativa, sosteniendo que el Pudente y la Claudia cuya boda celebra Marcial (IV 13) no son otros que las personas homónimas a los que manda saludos San Pablo en una carta a Timoteo (II 4, 21); y alborozado ante la idea, soñó con que "algún rayito tembloroso de la luz eterna" pudiera haber brillado para el epigramatista de Bílbilis, condenado de otra suerte a tostarse a perpetuidad en las llamas del infierno. Camden, el gran historiador inglés, aceptó de buen grado la identificación propuesta por Claverio, identificación que fue negada, en cambio, y con insólita vehemencia por nuestro ya viejo conocido, el padre Matías Rader ${ }^{263}$. Ahora la Crónica de Julián Pérez viene a disipar

${ }^{261}$ Iuliani Petri archipresbyteri S. Iustae Chronicon cum eiusdem adversariis et de eremiteriis Hispanis brevis descriptio atque ab eodem variorum carminum collectio, ex Bibliotheca Olivarensi, Lutetiae Parisiorum, 1628. Cito por número y página o bien por $A d u$. cuando me refiero a los Aduersaria, incluidos en el mismo volumen.

${ }^{262}$ Antigüedades, f. 71r.

263 Ad M. Valerii Martialis epigrammaton libros omnes... curae secundae, Ingolstadii, 1611, p. 4: "Ego tamen nondum inducor ut hoc ad animum admittam, 
cualquier duda, si es que la había: "Hubo en Roma dos Pudentes, de los que se acordó Pablo al escribir a los romanos: el uno un santo varón de linaje senatorial, discípulo de Pedro, que se casó con Claudia; el otro un centurión primipilo, un hombre impío; Marcial mencionó a uno y otro en sus poesías" (288, p. 63) ${ }^{264}$. Comentario de Ramírez de Prado: "prefiero la autoridad de Julián" a la crítica negativa del odiado y bilioso jesuita. Todos contentos, pues.

Claverio había mostrado el camino. Como Román de la Higuera era un excelente y desvergonzado aprendiz, pronto los epigramas de Marcial se poblaron de cristianos devotísimos. Sabemos que en el anfiteatro Flavio fueron representadas a lo vivo tanto las muertes del bandido Lauréolo (Spect. 7) y de Dédalo (Spect. 8) como la hazaña de Mucio Escévola (I 22; VIII 30; X 25); y también sabemos que Domiciano ordenó perseguir a los cristianos. Pues bien, la fértil imaginación del jesuita no dudó en unir esos datos inconexos, convirtiendo a los reos condenados en santos. Así lo hizo ya en el Cronicón de Dextro, anotando en el año 60, el 811 de Roma: "Marcial en su epigrama 7 y 8 llama Lauréolos y Dédalos volantes a los mártires crucificados"265 y en el 86 y 837 de Roma: "Gayo Valerio Léntulo, varón consular, representó el Lauréolo cristiano para complacer a Domiciano", noticia ésta sacada casi al pie de la letra de Juvenal (VIII 187). En vista del éxito obtenido por su primera falsifi-

nisi mihi sanctior et certior testis tabulas alias exhibeat, quod hic, quem adduxi, tam idoneus et sanctus videatur quam ipse Martialis est. Pudens autem ille et Claudia quos S. Paulus saluere iubet non videntur ii quos Martialis celebrat. Fuit enim A. Pudens Martialis centurio profanus et Encolpo puero transcriptus, non philosophus. Praeterea multo illis hi iuniores, de quibus lib. 4 . ep. 13 plenius. Pudens hospes sancti Petri ordinis iam tum senatorii, non centurio. Fabulis ergo gemina quae narrant Britannicae antiquitates, e nuperis scriptoribus concinnatae". ${ }^{264}$ El impío (como que tenía un puer delicatus llamado Encolpo) en I 32. El personaje parecer ser siempre el mismo (cf. también IV 29; VI 58; VII 11; 96, 3).

${ }^{265} \mathrm{La}$ Crónica de Dextro está editada cómodamente en el volumen 31 de la Patrología de Migne, que cito siempre remitiendo al año de la era cristiana y de Roma. En los códices consultados por R. Caro había diversas variantes; su texto da: "Laureolos, Teodolos, Daedalos volantes et Icaros" (Fragmentum Chronici vel Omnimodae historiae Flavii Lucii Dextri, Sevilla, 1637, f. 28v). A juicio de Caro, Teodolos significaría algo así como "taedam olentes" (j), como los sospechosos en la fe católica eran llamados despectivamente chamuscados. 
cación, Román de la Higuera volvió a repetir y ampliar estas fantasías en la Crónica del supuesto Julián: "A los mártires crucificados los llama Lauréolos Marcial en el epigrama VII" (30, p. 17); "En tiempo de Domiciano fueron llamados Mucios los mártires a los que se les quemaban las manos" (294, p. 65). Ni los más mínimos detalles se escapan a la diligencia del falsario gracias a nuestro poeta: hasta sabe las palabras que proferían los mártires cuando se negaban a sacrificar (295, p. 65): "Con frecuencia los cristianos, cuando se les ordenaba adorar a los dioses, decían 'No lo haré ni lo hago', como enseña Marcial" (X 25, 6).

En el Cronicón de Dextro anotó el jesuita en el año 86 y 837 de Roma: "San Julián, discípulo de San Pedro, querido por Marcial, es trasladado a ¿Vich? ¿Vigo?" ("Vicum transfertur"). Salta a la vista que este Marcial no es otro que el poeta, aunque no esté claro de dónde se sacó Román de la Higuera la familiaridad del santo (¿el Julián de III 25?) con el epigramatista ${ }^{266}$. El 25 de noviembre del año 86 (el 837 de Roma) padeció martirio por la fe Clemente, varón consular, amigo asimismo de Marcial (X 93, 1). En IV 55, 20 las ediciones de Calderini y Rader leían Suellos por Silaos, la variante aceptada por Ramírez de Prado y los filólogos modernos; de ahí salió la cohorte de celtíberos en cuyas filas militaban "Suelli iaculatores", oriundos de una Suel imaginaria homónima a la bética (al año 86 y 837 de Roma). En el año 100 y 851 de Roma, según el mismo Cronicón, murió Marcela Jantipe, hermana del obispo toledano Marcelo Eugenio. El Pseudo-Dextro añade una precisión notable: "Fue su madre Claudia Jantipe, ciudadana romana y de linaje clarísimo de Atenas, que tuvo una estatura más elevada de lo normal, de la cual se burla Marcial [VIII 60]". Y sin duda en honor del poeta indica la misma crónica que en el 94 y 845 de Roma los bilbilitanos abrazaron la fe de Cristo, añadiendo una frase ambigua que los editores arreglaron como pudieron: "effante Paterno" (Bivar) o "affectu paterno" (Caro); la primera variante me parece la más fidedigna, ya que un Paterno bilbilitano es citado asimismo como íntimo en Roma de Marcial (al año 112 y 863 de Roma; cf. XII 53, 2).

Gracias a la nueva Crónica de Julián salieron santificados otros amigos de Marcial, muy probablemente contra su voluntad. Así, recibieron la palma del martirio Casiano, citado por el poeta en III 64, 5

${ }^{266}$ Ya lo señaló R. Caro (ed. de Dextro, f. 44v): “Martialis Epigrammate 25. lib. 3. Iulianum quendam, non tamen ut amicum, incessit". 
(294, p. 65); Licinio o Liciniano (I 49, 3; 61, 11), que padeció el 7 de agosto en Como (53, p. 20); Cándido (II 24, 6), Paulo (II 20, 1; IV 17, etc.) y al parecer también un Lucio de Túy (I 107, 1; IV 55, 1; V 14, 5) ${ }^{267}$, "que fue a Roma desde la última Hispania" (los tres en 296, p. 65); Manciano (¿Mancino? ¿Marciano? ¿Mariano?) que, tras haber sido elegido obispo de Roma, murió tras haber padecido infinidad de tormentos bajo el reinado de Hadriano (289, p. 64); y para no desperdiciar ninguna ocasión, hasta el mismísimo Plinio el Joven que, bautizado por San Tito, arzobispo de Creta, habría sido martirizado en Como en la misma persecución de Hadriano (108, p. 31; 285, p. 62; 298, p. 66). Por fin, Mannio Liberato (XI 20, 5; o quizás Maneyo, el Naneyo de las ediciones modernas [V 14, 2; XI 61, 1]) y Bitínico Báyulo (II 26, 3; VI 50, 5; IX 8, 1; XII 78, 1) sufrieron martirio en Roma en los últimos años de Trajano; los dos estuvieron unidos a Marcial por lazos de amistad (23, p. 6). Ni que decir tiene que ya el Cronicón de Dextro había hecho cristiano oculto a Séneca, discípulo de San Pablo (a los años 64 y 815; 66 y 817 de Roma).

La Crónica de Julián fue una bendición para el santoral hispano. En efecto, el obispo de Toledo San Marcelo Eugenio, que vino a Hispania primero con San Pedro en el 50 y después con Aulo Cornelio Palma, también toledano, en el 91 (cf. Mart. XII 9) -así lo había sancionado el Cronicón del Pseudo-Dextro higueriano-, trajo consigo la devoción por varios santos, todos ellos relacionados con amigos del poeta: la fiesta de Santa Petronila, hija de San Pedro (31 de mayo) ${ }^{268}$, que se vio obligada a casarse con Valerio Flaco de Padua (el Flaco de VII 87, 1 y XII 74, 5), amicísimo de Marcial (291, p. 64), o la fiesta de los mártires Nereo y Aquiles (12 de mayo), que padecieron en Roma bajo el consular Lanicio Rufo (292, p. 64), otro de los amigotes del poeta (el Rufo de I 10, 1; II 11, 1; 29, 1; 48, 7, etc. $)^{269}$. Fue también San Marcelo quien escribió la pasión de San Marón y compañeros mártires (293, p. 65 [15 de abril]), el mismo

${ }^{267}$ Al hispano Lucio (entiéndase Liciniano), citado por Marcial como gloria de Hispania (I 49, 3; 62, 11), lo hace poeta Rafael Volaterrano (Commentariorum. urbanorum liber XVI [Lyon, 1552, c. 506]).

${ }^{268}$ La citó también Román de la Higuera en el Cronicón de Dextro, al año 34.

269 Ya había hablado de estos mártires el Pseudo-Dextro, poniéndolos en relación con el obispo Marcelo: "A. C. 91. A. R. 842. Nereus, Achilleus, et Flavia Domitilla relegati crebis sancti M. Marcelli, post Toletanorum pontificis, litteris recreati, tandem pro fide caesi, ad martyrii lauream evolant". 
Marón de quien se ríe Marcial (XII 90, 1), así como la vida de Santa Flavia Domitila (12 de mayo), al hilo de la cual refirió también los hechos de Vibio Serviliano (Adu. 505, p. 119), soldado y ciudadano romano citado por el epigramatista (el Velio [Vebio o Vibio en ediciones antiguas] de IX 32,1$)$.

Otra saga hispana la forman los Santos Crispo o Críspulo (V 61, 1) y Restituto (X 87, 20), amigos de Marcial y de Juvenal, que vinieron a España y, tras predicar en la Bética, padecieron los dos el mismo día (el 10 de junio), Críspulo en Caravaca y Restituto en $\operatorname{Argos}^{270}$, en el camino de Caravaca a Murcia (Adu. 4, p. 2; 84 y 96, p. 23) ${ }^{271}$.

En VII 95 se burla el poeta de un tal Lino, que en pleno diciembre y con una vela colgando de la nariz y la barba helada besuqueaba a cuantos le salieran al paso. Nuestro cronista nos descubre solícito quién era ese hombre inoportuno: "Marcial se acuerda del Papa San Lino, que daba ósculos a la manera cristiana" (32, p. 17).

Una tal Maximina, ya vieja, tenía sólo tres dientes, por lo que Marcial le recomendó que no se riera jamás (II 41). Julián nos cuenta su historia, llamándola Maximila: "fue la mujer del consul Egia y cuñada de Plinio [sin duda se piensa en la ornatissima femina de Plin. Ep. X 5, 2 IV 11, 6], la cual sepultó a su santo maestro Antisio y habiendo vuelto a Roma vivió largo tiempo" (290, p. 64); bonita y lógica explicación de por qué la mujer se había quedado desdentada ${ }^{272}$.

${ }^{270}$ Argos (o Caravaca) es el nombre de un río de poco caudal, que nace en las Ramblas de las Buitreras (P. Madoz, Diccionario geográfico-estadístico-histórico de España y sus provincias de Ultramar, Madrid, 1845, II, p. 550 b).

271 Sobre la cruz de Caravaca Román de la Higuera compuso al parecer un libro que se publicó bajo el nombre de otro, según se desprende del comentario de Juan Luis de la Cerda a Virgilio (III, p. 261 b); en este pasaje lo llama "doctissimus uir".

272 Ya había hablado de ella en el Pseudo-Dextro: "A. C. 100. A. R. 851. Antima [así Bivar : Antonia mejor Caro] Maximilla conjux Aegeae Patrarum (Caro: Patrorum Bivar) in Achaia proconsulis, a B. Andrea conversa, in antrum se abdidit mortem post mariti. Fuit haec Novocomensis, Plinii Junioris consanguinea; post (post om. Caro) nupsit C. Fonteio Capitoni, inque (inque Bivar : Post Caro) Nicomediam delata pro Christi fide 4 Maii patitur". El epigrama fue imitado por B. L. de Argensola, como queda dicho. 
Marcial se chancea de un tal Munna, que vendía vino malo y adulterado (X 36, 3); pues bien, "bajo el nombre de Muna se cree que se ensañó Marcial con San Marco romano" (Adu. 454, p. 105).

Otro blanco de las burlas de Marcial es Amiano (II 4, 1; 17, 4; IV 70, 1). El falso cronista sabe que fue prefecto de Roma bajo Trajano y que bajo su mandato padecieron Serviliano (sin duda el ya citado Vibio Serviliano) y Sulpicio (Adu. 1, p. 1).

Convertido en una máquina de hacer santos, Román de la Higuera dio la corona del martirio a Marcia Matidia, hispana, la única hermana de Trajano, que habría padecido en la persecución de Antonino Pío el 3 de marzo (Adu. 78, p. 2). Y para no desaprovechar a los demás poetas de la época, identificó a Vitorio Marcelo, el destinatario de un poema de Estacio (Silu. IV 4), con un hermano de San Marcelo, llamado Vital (55, p. 20). Es lo que había hecho el jesuita en el Pseudo-Dextro, cuando en el año 100 y 851 de Roma convirtió a M. Marcelo, "excellens poeta et orator", en amigo de Juvenal, Persio (que le habría dedicado su cuarta sátira), Séneca, Galo (un conocido de Estacio) y el propio Estacio; aunque Caro $^{273}$ considera que es hermano de Marcelo Eugenio, insigne taumaturgo y obispo de Toledo, a mi juicio se trata siempre del mismo personaje ficticio.

Román de la Higuera, que tan mañosamente supo enredar nuestra historia, no fue ni siquiera un buen latinista. El nombre del santo llamado Críspulo procede en realidad de un error de comprensión del adjetivo crispulus, 'el que tiene ricitos' (designando a un aparente afeminado, como Gitón es llamado por Petronio [58, 2] cepa cirrata, 'cebolla con rizos'). Parecido origen tiene Báyulo, sacado de un sustantivo baiulus, 'portador'. Estos deslices pudieran haberle ayudado a hacer pasar su obra por una crónica medieval, tal y como pretendía, pero sus falsificaciones son demasiado burdas y de inmediato cantan; lo chocante es que recibieran el marchamo de humanistas tan expertos como Rodrigo Caro y el propio Ramírez de Prado ${ }^{274}$.

273 En su edición de Dextro, f. 54v.

${ }^{274} \mathrm{He}$ intentado dar una explicación de esta aporía en "Judíos y conversos en los falsos cronicones" en A. Molinié-J.P.Duviols, Inquisition d'Espagne, París, 2003, pp. 21-43. 


\section{Tomás Tamayo de Vargas (1588-1641)}

Uno de los más firmes defensores de la veracidad de los falsos cronicones fue el cronista Tomás Tamayo de Vargas, un hombre ambicioso y sin muchos escrúpulos que puso su no pequeña erudición al servicio de una causa indigna. Tamayo, además de defender a capa y espada la autenticidad del Pseudo-Dextro, quiso celebrar la gloria de Toledo, la ciudad donde había estudiado, trazando la vida de su presunto obispo Marco Marcelo Eugenio sobre los datos higuerianos y algunos otros de su cosecha, que tomó de Marcial siguiendo el ejemplo de Román de la Higuera. La autoridad del poeta le vino de perlas para elucidar incluso la fecha de nacimiento del santo: en efecto, el epigrama III 6 está dedicado, según Tamayo, al primado de Toledo y apóstol de las Españas, que habría nacido, por tanto, el 18 de mayo ${ }^{275}$.

Un favor prestó de paso Tamayo a su admirado Ramírez de Prado $^{276}$. Rader había interpretado palma en XII 9 como referido a una victoria de Trajano sobre escitas y dacios. Un pasaje de Dextro pareció venir a confirmar la identidad de Palma con el famoso legado de Trajano. Puntada justificada de Tamayo y jubilosa satisfacción del prócer: "No sé como hombre tan docto se persuadió que podía, aun con duda, la elegancia de Marcial dezir por la victoria de César 'La palma rige a nuestros españoles'"'277.

275 Novedades antiguas de España o Flavio Lucio Dextro, caballero español de Barcelona, prefecto-pretorio de Oriente, governador de Toledo por los años del Señor de CCCC, defendido. Verdad de Flavio Dextro, Madrid, 1624, f. 22r. Así razona Tamayo su deducción: "Parece insinúa aquí Marcial que nuestro Eugenio era christiano en el segundo verso: tuis bis celebranda sacris: celebra el día de su nacimiento, festivo para Eugenio por aver nacido y por ser christiano, llamando a los sacrificios de su celebración "suyos", tuis sacris, por particulares y no de los romanos". Otros epigramas dirigidos al santo son, siempre según Tamayo, VI 11 y X 73. Tamayo puso también en relación a Estacio con Marcelo: el poeta le habría dedicado el libro IV de las Silvas (f. 23v).

276 En la obra citada menciona con elogio a D. Lorenzo, "de cuyas letras es verdadera prueba el testimonio de tantos estrangeros, como con admiración de sus escriptos las celebran" (f. 88r).

277 Verdad de Flavio Dextro, f. 100v. 
Hora es de terminar este estudio, que deja en nuestra boca un sabor agridulce. Hemos visto cómo el patriotismo español, o tal vez la propaganda patriótica, que no es lo mismo, celebró como una gloria propia la fama de Marcial, olvidado durante tantos siglos. En Aragón sobre todo. En 1646 Andrés de Uztarroz alabó la agudeza de Baltasar Gracián como virtud congénita a la tierra, pues éste tenía "por cuna a Bílbilis (hoy Calatayud), patria augusta de Marcial: que también se hereda el ingenio como la naturaleza"278. A su vez, y en el mismo año, el carmelita fray Jerónimo de San José puso por las nubes la sutileza con que Uztarroz había trazado el Obelisco erigido en Zaragoza para celebrar las exequias del príncipe Baltasar Carlos, trayendo también a colación a Marcial $^{279}$. Durante el siglo XVII proliferaron a lo largo y a lo ancho de España los traductores e imitadores del epigramatista, siempre dentro de los límites impuestos por la pudicicia cristiana; de tantos entusiastas admiradores sólo Lorenzo Ramírez de Prado, un extremeño, tuvo agallas para dedicar al poeta bilbilitano sus vigilias filológicas. Los mejores y más extensos comentarios se los llevaron otros autores: Virgilio, Petronio y Séneca; y es llamativo que a Séneca lo estudiase un jesuita trasterrado y casi sentido como extranjero, Martín del Río. He aquí otra de las frecuentes contradicciones de nuestra historia: de ese Marcial tan orgullosamente pregonado como "español" hubiésemos esperado más ediciones en la Península Ibérica; sin embargo, la única que apareció, la de Ramírez de Prado, vio la luz en París. Después, ya en el s. XVIII, hubo quien, emulando a Francisco Vergara y sobre todo a José Escalígero ${ }^{280}$,

278 R. del Arco, La erudición española en el siglo XVII y el cronista de Aragón Andrés de Uztarroz, Madrid, 1959, I, p. 413. Es notable, sin embargo, que B. L. de Argensola no citara a Marcial entre los poetas normativos de la Antigüedad (Rimas, 43, 97 [ed. de J. M. Blecua, Clás. Cast., I, p. 57]), aunque sí lo menciona entre los tres que lo entretenían: Ovidio, Horacio y Marcial (Rimas, IX 63 [II, p. 156]). Cf. asimismo sus epigramas laudatorios de Marcial: Rimas 181 (II, p. 116); XLV (II, p.206) y XLVI (II, p. 207).

279 Ibidem, I, p. 449.

280 Florilegium Epigrammatum Martialis. Josephus Scaliger Iul. Caesaris F. vertit Graece. Ad Isaacium Casaubonium, Lutetiae, ex Typographia Roberti Stephani, MDCVII. Al final: Excudebat Ioannes Iannonus in typographia Rob. Stephani 
puso en griego algunos epigramas de Marcial, algunos de ellos bastante obscenos (por ello no fueron publicados entre sus Opera omnia por P. Wesselingio): el deán Martí281. Estas curiosas extravagancias no fueron más que pirotecnias filológicas: el poeta de Bílbilis siguió siendo un poeta descuidado por los impresores de nuestra patria. Sin embargo, Marcial continuó regocijando con su lectura a los españoles; y, como creo haber demostrado, más de uno, aunque fuera de pasada, contribuyó de manera positiva a la comprensión de sus versos, mucho más difíciles de lo que normalmente se piensa.

APÉNDICE. Interrogatorio de D. Lorenzo Ramírez de Prado ante D. Francisco de Contreras (23 de agosto de 1612). A.H.N., Consejos, leg. 30.197 nº 3, f. 21r.

En la villa de Madrid, veinte y tres días del mes de agosto de mill y seisçientos y doze años, el señor Don Francisco de Contreras, del Consejo de Su Magestad, mandó pareçer ante sí personalmente a Don Lorenzo Ramírez de Prado, residente en esta Corte, y haviendo rezivido d'él juramento en forma de derecho le preguntó lo siguiente:

Fue preguntado, haviéndosele mostrado un libro impreso que tiene veinte foxas y comienza Tipographus y acaba tribuendum, con el nombre de autor que dize Don Lorenzo Ramírez de Prado en la epístola dedicatoria para el conde de Salinas, y haviéndole visto, dixo que desde la dicha epístola dedicatoria hasta el fin del dicho libro reconoze qu'es trabaxo suyo y qu'él lo conpusso, y que la primera foxa que comienza Tipographus hasta donde dize Vale en la foxa segunda no es suyo, ni save cúyo es.

Preguntado qué motibo tubo para escrevir este libro, dixo qu'estando en la ciudad de Salamanca en sus estudios para exerçitar el conozimiento de buenas letras y el de las buenas letras de la Facultad de Leyes que professa, porque también aprende quien escrive iba comentado a Marzial, llebado de la afitión de ser poeeta español; y teniendo comentados el primero libro de los Espectáculos y quatro siguientes por solamente asistir, como dicho tiene, al exerçiçio de las

anno M.DC.VII. Casaubon en su prefacio puso por las nubes a Scaliger, que en 1601 había traducido en la cama los epigramas, ordenados por temas, para aliviar sus insomnios: un prodigio de virtuosismo.

${ }^{281}$ Cf. L. Gil, "Entre clérigos anda el juego. La versión griega de los Martialis disticha del deán Martí y el Lusus convivialis de Interián de Ayala", Cuad. Filol. Clás (E.G.)., I (1991) 20ss. 
letras, no con designio ni determinaçión de darlo a la luz, se le llevaron a París el dicho comento y le estanparon sin lizençia suya, como consta de la carta del inpresor puesta al prinçipio del dicho libro, y qu'este declarante no hizo carta dedicatoria al lector ni a otra persona; la qual impresión fue motibo de que Mateo Radero, alemán, de la Conpañía de Jesús, hiziese segunda impresión de un comento que havía fecho sobre Marzial antes que el d'este declarante se imprimiese, en la qual dize las palabras al prinzipio de una carta dedicatoria, que pide y suplica al Consejo la mande leer, las quales fueron caussa de que en su satisfazión, con la modestia que se deve a sí propio, este declarante hiziesse el libro que se le a mostrado y que se hecha de ver haver profesado siempre tenerla, pues haviendo escripto contra él otro franzés [Musambert], no le respondió. En el qual dicho libro con dotrina de santos procura solamente probar que su intento, aunque de mozo, quando hizo el dicho comento de Marzial, fue sano y senzillo, y ansí no le responde a lo que le dize fuera d'esto. Pide y suplica al Consejo le haga merçed de faborezerle, alentándole sus estudios, no dando lugar a que las naziones extrangeras nos llamen por escripto y de palabra bárbaros, juzgando como juzgan que somos axenos de buenas letras y conozimiento de lenguas, siendo ansí que en todas facultades es lo contrario; y qu'este declarante de su hedad, que no es mucha, a conpuesto seis y tiene lizençia y preuilegio de Su Magestad para imprimir otro y dos de su padre, para hacer lo mismo.

Preguntado si tiene en su poder los dichos comentos de Marzial qu'él hizo el que hizo el padre Matheo Radero y los libros que se hizieron de su parte y de la del dicho padre Mateo Radero sobre los dichos comentos y si se imprimieron todos y quántos cuerpos de los unos y de los otros y con qué lizençia y por qué impresores, dixo que el comento primero que hizo de Marzial este declarante ya tiene declarado cómo fue en París su inpresión y sin sabiduría suya; pero lo que save es que un Fulano Bichon, franzés, librero, qu'está aquí, a quien se le entregó este declarante para llevarle a Don Caro Ramírez, hermano d'este declarante, desde Salamanca a Valladolid, donde estava, el dicho Bichon le llevó a imprimir a París de Franzia, y él después de la dicha inpresión metió en estos reinos los cuerpos de libros que se imprimieron y le dio a este confesante quatro o çinco libros de los impresos y los demás, que no save quántos heran, entiende que los vendió por su quenta; pero que ni el imprimirlos ni el meter los impresos en estos reinos fue por horden d'este confesante y que sólo lo supo quando se estavan imprimiendo; y entonzes hizo conzierto con él que, pues se los imprimía y hera trabaxo suyo, si se vendían dentro de çierto tienpo, le avía de dar çierta cantidad de libros, y si no, qu'él le daría, dándole çinquenta o veinte y çinco ducados, otros tantos libros; sobre lo qual le puso demanda. $Y$ en quanto toca a este libro que se le a mostrado, la verdad es qu'el tubo dos traslados, y aviéndole faltado uno, a cabo de algunos días le dieron doze exenplares d'él impresos con la dicha carta dedicatoria, los quales repartió entre algunos amigos; y entiende que tiene en su 
poder dos o tres, y que los demás dio uno al señor Gil Ramírez de Arellano y otro al señor Melchor de Molina y dos en la Conpañía a dos padres d'ella que son al padre [Juan de] Pineda y al padre Juan Luis [de la Cerda], y tanbién se acuerda aver dado otro al dicho padre Pineda y otro a Juan Baptista Labaña y los otros no se acuerda al presente a quién los dio; que, acordándose, lo declarará.

Preguntado quién fue la persona que dio a este declarante los dichos libros impresos, dixo que le pareze se los dio un honbre como impresor; y que si le be, lo conozerá.

Preguntado en qué le pareszio impresor el dicho hombre, dixo que en el vestido, porque era maltraído, como ofizial, y grasiento.

Preguntado si entendió qu'el dicho hombre hera inpresor d'esta Corte, dixo que no lo puede afirmar.

Preguntado si save que algún librero d'esta Corte aya tenido en su tienda algunos cuerpos d'estos libros y vendídolos, o save o conoze por la vista del libro dónde se aya fecho la impressión d'él, dixo que no save lo uno ni lo ottro ni la lizençia ni zensura con que se imprimió este ni el otro libro, y solamente save que para la impresión del comento de Marzial por entonzes no hera menester lizençia, caso qu'él le enbiara a imprimir, por no aver salido la premagtica [sic] en que Su Magestad manda no se imprima fuera del reino, sino solamente la zensura de los inquisidores de los puertos que los exsaminen antes que pasen; y si los aprueban, los dexan passar, y si no, los detienen, como se a fecho con todos los libros.

Preguntado qué tanto tiempo ha que dieron a este declarante este último libro de veinte foxas inpreso y los demás que le dieron con él, dixo que abrá un mes poco más o menos. E aviéndosele dicho que pareze qu'es cosa muy berisimil que, siendo obra suya la d'este dicho libro e impresa y con tanto cuidado como pareze qu'está fecha la impresión, no pueda ser que no sepa el mismo autor del libro, que confiesa este declarante que lo es él, quién le imprimió y dónde, mayormente haviendo venido a sus manos los cuerpos de libros que tiene dichos, dixo que dize lo que dicho tiene. $Y$ en lo que toca a los libros del padre Mateo Radero los a conprado de algunos libreros y no save quién los metió en el reino, y los conpró como a conprado otros muchos; y aviendo traído tres libros grandes ante su merçed, el uno del padre Mateo Radero, qu'es el comento de Marzial, inpreso en Golostadio año de 1602, y el segundo qu'es el comento d'este declarante sobr'el mismo Marzial, inpreso en París año de 1607, y el terzero del mismo padre Mateo Radero, inpreso también en Golostadio año de 1611, su merçed mandó quedasen en su poder y el dicho Don Lorenço los dexó. Y esta es la verdad para el juramento que hizo. Y haviéndosele leído esta confessión, se afirmó y ratificó en ella y lo firmó de su mano, y dixo ser de hedad de veinte e ocho años. D. Lorenço Ramírez de Prado. 